
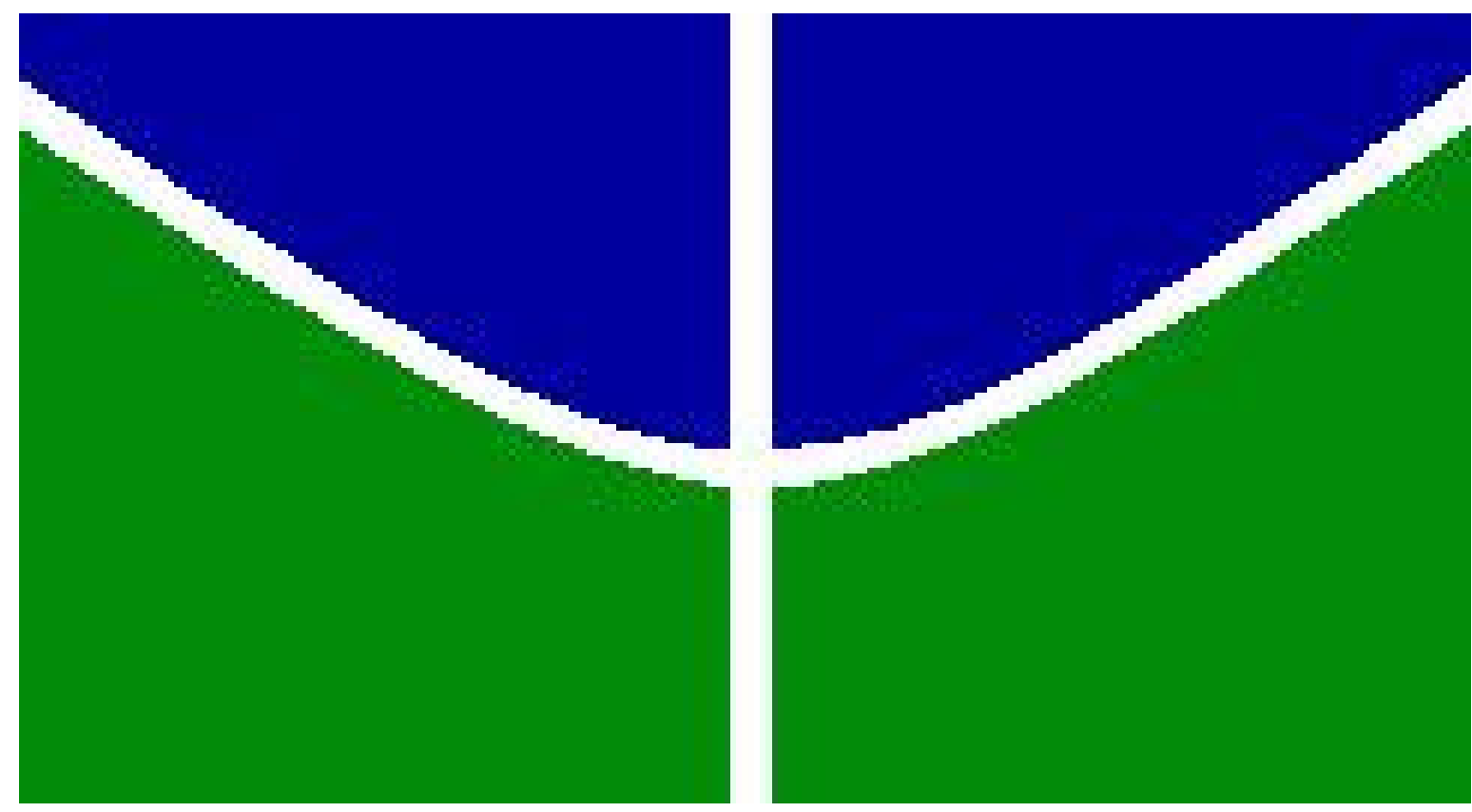

APROVEITAMENTO ENERGÉTICO DE RESÍDUOS AGROINDUSTRIAIS NO DISTRITO FEDERAL

Aline Faleiro Dionizio

DISSERTAÇÃO DE MESTRADO EM CIÊNCIAS FLORESTAIS

FACULDADE DE TECNOLOGIA

UNIVERSIDADE DE BRASÍLIA 
UNIVERSIDADE DE BRASÍLIA - UNB

FACULDADE DE TECNOLOGIA

DEPARTAMENTO DE ENGENHARIA FLORESTAL

\title{
APROVEITAMENTO ENERGÉTICO DE RESÍDUOS AGROINDUSTRIAIS NO DISTRITO FEDERAL
}

\author{
Aline Faleiro Dionizio
}

Orientador: Prof. Dr. Ailton Teixeira do Vale

DISSERTAÇÃO DE MESTRADO EM CIÊNCIAS FLORESTAIS

PUBLICAÇÃO: PPGEFL.DM - 289/2017

BRASÍLIA/DF: FEVEREIRO - 2017 


\author{
UNIVERSIDADE DE BRASÍLIA - UNB \\ FACULDADE DE TECNOLOGIA \\ DEPARTAMENTO DE ENGENHARIA FLORESTAL
}

APROVEITAMENTO ENERGÉTICO DE RESÍDUOS AGROINDUSTRIAIS NO

DISTRITO FEDERAL

Aline Faleiro Dionizio

DISSERTAÇÃO DE MESTRADO ACADÊMICO SUBMETIDO AO PROGRAMA DE PÓS GRADUAÇÃO EM CIÊNCIAS FLORESTAIS, DO DEPARTAMENTO DE ENGENHARIA FLORESTAL, DA FACULDADE DE TECNOLOGIA DA UNIVERSIDADE DE BRASÍLIA, COMO PARTE DOS REQUISITOS NECESSÁRIOS PARA A OBTENÇÃO DO GRAU DE MESTRE.

Aprovada por:

Prof.: Dr. Ailton Teixeira do Vale (Departamento de Engenharia Florestal - EFL/UNB) (Orientador)

Prof.: Dr. Thiago Oliveira Rodrigues (Departamento de Engenharia Florestal - EFL/UNB) (Examinador interno)

Prof.: Dr. Carlos Roberto Sette Júnior (Departamento de Engenharia Florestal - EA/UFG) (Examinador externo)

Prof.: Dr. Alexandre Florian da Costa (Departamento de Engenharia Florestal - EFL/UNB) (Examinador suplente) 


\section{Dionizio, Aline Faleiro}

DD592a Aproveitamento energético de resíduos agroindustriais no Distrito Federal/ Aline Faleiro Dionizio; orientador Ailton Teixeira Vale.

Brasília, 2017.

$97 \mathrm{p}$.

Dissertação (Mestrado - Mestrado em Ciências Florestais) -Universidade de Brasília, 2017.

1. Biomassa. 2. Combustão. 3. Carbonização. 4. Briquetagem. I. Vale, Ailton Teixeira, orient. II. Título.

\section{REFERÊNCIA BIBLIOGRÁFICA}

DIONIZIO, A. F. (2017). Aproveitamento energético de resíduos agroindustriais no Distrito Federal. Dissertação de Mestrado em Ciências Florestais, Publicação PPGEFL.DM - 289/2017, Departamento de Engenharia Florestal, Universidade de Brasília, Brasília, DF, $97 \mathrm{p}$.

\section{CESSÃO DE DIREITOS}

AUTOR: Aline Faleiro Dionizio TÍTULO: Aproveitamento energético de resíduos agroindustriais no Distrito Federal.

GRAU: Mestre

ANO: 2017

É concedida à Universidade de Brasília permissão para reproduzir cópias desta dissertação de mestrado e para emprestar ou vender tais cópias somente para propósitos acadêmicos e científicos. $\mathrm{O}$ autor reserva outros direitos de publicação e nenhuma parte dessa dissertação de mestrado pode ser reproduzida sem autorização por escrito do autor.

\footnotetext{
Aline Faleiro Dionizio

E-mail: alinefaleiro@gmail.com
} 
"É melhor tentar e falhar, que preocupar-se e ver a vida passar; É melhor tentar, ainda que em vão que sentar-se, fazendo nada até o final." Martin Luther King 
À minha mãe, por acreditar em mim, sempre me apoiar na realização dos meus sonhos e não me deixar desistir nunca.

DEDICO 


\section{AGRADECIMENTOS}

A DEUS, em primeiro lugar, que me permitiu alcançar está realização.

Ao Professor e orientador, Dr. Ailton Teixeira do Vale, por sua dedicada orientação, pelos ensinamentos e confiança.

Ao MSc. Vanduí Dantas pelo auxílio no Laboratório de Tecnologia da Madeira da FAL.

Aos Professores Carlos e Thiago, pela participação na banca avaliadora.

À minha família, por acreditarem em mim, me apoiarem nas minhas decisões e me ajudarem a não desistir. Vocês são meus exemplos e minhas inspirações.

Á Susylaine, demônio da minha vida, por me lembrar sempre que tinha uma dissertação para terminar.

À Universidade de Brasília, ao departamento de Pós-Graduação da Engenharia florestal e ao Laboratório de Produtos Florestais-LPF/SFB, pela oportunidade de ter desenvolvido este trabalho e apoio para meu desenvolvimento acadêmico;

À CAPES pela bolsa de estudos concedida.

Por fim, agradeço imensamente a todos que de alguma forma contribuíram e que torceram por esta conquista. 


\title{
RESUMO
}

\section{APROVEITAMENTO ENERGÉTICO DE RESÍDUOS AGROINDUSTRIAIS NO DISTRITO FEDERAL}

\author{
Autor: Aline Faleiro Dionizio \\ Orientador: Ailton Teixeira do Vale \\ Programa de Pós-graduação em Ciências Florestais \\ Brasília, fevereiro (2017)
}

No atual contexto energético nacional a diversificação da matriz energética e o desenvolvimento de tecnologias limpas tornam-se cada vez mais necessário para suprir a crescente demanda frente a diminuição na oferta dos combustíveis fósseis, além das explícitas vantagens ambientais diante das alarmantes mudanças climáticas em curso no planeta. Nesse sentido, resíduos de biomassa das mais variadas origens despontam-se como interessantes alternativas energéticas, no entanto o seu aproveitamento é limitado pelo pouco conhecimento sobre seu potencial energético. O presente estudo tem como objetivo avaliar o potencial energético de resíduos agroflorestais, visando à obtenção de produtos energéticos renováveis com maior valor agregado. Neste sentido os resíduos de casca de café, palha de feijão, madeira de construção civil, madeireira e sabugo de milho foram avaliados in natura, carbonizados e compactados. As características analisadas foram: umidade, densidade do granel, granulometria, análise imediata, composição química, análise elementar, poder calorífico superior e útil e a densidade energética. Os dados foram submetidos à análise de variância e as médias comparadas através do teste de Tukey a 5\% de significância. Ao final do estudo pôde-se concluir que a casca de café in natura apresentou as melhores propriedades para uso em combustão direta. O carvão de resíduos de madeira apresentou melhores propriedades para fins energéticos e o carvão da palha de feijão apresentou características inferiores às demais biomassas analisadas. Quanto aos briquetes, a quirela de milho e de sorgo, por terem altos teores de amido, podem ser utilizadas como aglutinantes, diminuindo os custos de produção de briquetes.

Palavras-chave: biomassa, combustão, carbonização, briquete. 


\begin{abstract}
UTILIZATION ENERGY AGROINDUSTRIAL WASTE IN THE FEDERAL DISTRICT
\end{abstract}

Author: Aline Faleiro Dionizio

Supervisor: Ailton Teixeira do Vale

Programa de Pós-graduação em Ciências Florestais

Brasília, february (2017).

In the current energy context the diversification of the energetic matrix and the development of sustainable technologies has become increasingly necessary in order to meet growing demand of a reduction in the supply of fossil fuels, in addition to the explicit environmental advantages front of alarming ongoing climate change on the planet. In this sense, biomass residuals of the most varied origins appear as interesting energetic alternatives, however this use is limited by the summary knowledge about this energetic potential. The present study evaluates the energy potential of agroforestry residues to obtaining renewable energy products with higher value added. This way coffee husk residues, bean straw, construction timber, wood and corn cob were evaluated "in natura", carbonized and compacted. The analyzed characteristics were: moisture, bulk density, grain size, immediate analysis, chemical composition, elemental analysis, superior and useful calorific value and energy density. In fact, the data were submitted to analysis of variance and were compared using the Tukey test at $5 \%$ of significance. At the end of the study was possible to conclude that coffee husk in natura presented the best properties for use in direct combustion. The charcoal residuals presented better properties for energy purposes and the charcoal of the bean straw presented lower characteristics inferior to the other biomasses analyzed. The corn and sorghum quirela have high starch contents, so they can be used to agglutinate, reducing the production costs of briquettes.

KEY-WORDS: Biomass, combustion, carbonization, briquette. 


\section{LISTA DE TABELAS}

Tabela 1. Quantidade de café colhida em 2015 e o total de cascas geradas.............. 7

Tabela 2. Produção total de grãos de milho e resíduos - Safra 2015...................... 8

Tabela 3. Produção de feijão, resíduos gerados e passíveis de serem aproveitados

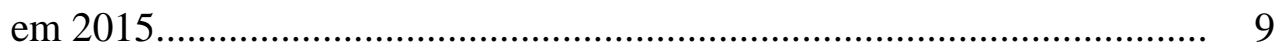

Tabela 4. Análise elementar.............................................................................. 19

Tabela 5. Teor de umidade e densidade a granel................................................. 42

Tabela 6. Valores médios de teor de materiais voláteis, teor de cinzas e teor de carbono fixo.

Tabela 7. Valores de "F" para teor de materiais voláteis, teor de cinzas e teor de carbono fixo.

Tabela 8. Teste de Tukey para as médias de teor de material volátil (MV), teor de cinzas $(\mathrm{CZ})$ e carbono fixo $(\mathrm{CF})$.

Tabela 9. Análise química.

Tabela 10. Valores de "F" para o teor de extrativos (TE), lignina total (LT), cinzas (CZ) e holocelulose (HC).

Tabela 11. Teste de Tukey para as médias de teor de extrativos, lignina total, cinzas e holocelulose.

Tabela 12. Análise elementar dos resíduos in natura.

Tabela 13. Poder calorífico superior (PCS), poder calorífico útil (PCU) e densidade energética (DE).

Tabela 14. Tabela 14. Valores de "F" para poder calorífico superior (PCS), poder calorífico útil (PCU) e densidade energética (DE).

Tabela 15. Teste de Tukey para as médias de poder calorifico superior (PCS), poder calorifico útil (PCU) e densidade energética (DE)...................... 51

Tabela 16. Rendimento gravimétrico da carbonização dos resíduos......................... 55

Tabela 17. Valor de "F" para rendimento gravimétrico do carvão............................ 56

Tabela 18. Teste de tukey para rendimento gravimétrico do carvão (RGC).............. 56

Tabela 19. Análise elementar dos carvões dos resíduos.......................................... 57 
Tabela 20. Análise imediata.

Tabela 21. Valores de "F" para teor de materiais voláteis (MV), teor de cinzas (CZ) e teor de carbono fixo (CF) 58

Tabela 22. Teste Tukey da análise imediata.

Tabela 23. Poder calorífico superior, poder calorífico útil, densidade do granel e densidade energética do carvão..

Tabela 24. Valores de "F" para poder calorífico superior (PCS), poder calorífico útil (PCU) e densidade energética (DE).

Tabela 25. Teste de Tukey poder calorífico superior (PCS), poder calorífico útil (PCU), densidade do grandel (Dg) e densidade energética (DE)

Tabela 26. Valores médios das umidades de equilíbrio higroscópico, densidade aparente e resistência a compressão paralela.

Tabela 27. Valores de "F" para umidade de equilíbrio e densidade aparente.

Tabela 28. Análise da interação pressão x aglutinante

Tabela 29. Análise da interação aglutinante x pressão......

Tabela 30. Valores de "F" para resistência a compressão paralela........................... 65

Tabela 31. Análise imediata dos briquetes....................................................... 66

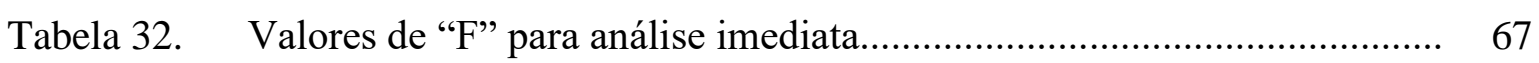

Tabela 33. Poder calorífico superior e densidade energética.................................. 68

Tabela 34. Valores de "F" para poder calorífico superior e densidade energética. .... 68 


\section{LISTA DE FIGURAS}

Figura 1. Oferta interna de energia........................................................ 3

Figura 2. Etapas da industrialização e produção de resíduos de madeira......... 5

Figura 3. Estrutura do grão de café................................................................. 7

Figura 4. Fluxograma de briquetes de finos de carvão vegetal....................... 15

Figura 5. Biomassas utilizadas.............................................................. 21

Figura 6. Metodologia utilizada para classificação granulométrica................ 23

Figura 7. Baterias de extratores Soxhlet................................................... 26

Figura 8. Fluxograma de determinação do teor de lignina ácida, insolúvel e

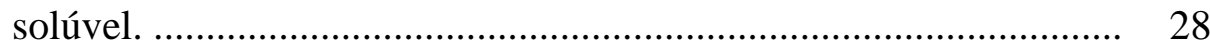

Figura 9. Etapas da separação da lignina........................................................ 29

Figura 11. Analisador elementar.................................................................. 32

Figura 12. Bomba calorimétrica................................................................ 32

Figura 13. Perfil térmico de carbonização..................................................... 34

Figura 14. Reator de carbonização................................................................. 35

Figura 15. Resíduos utilizados como aglutinante........................................... 37

Figura 16. Sistema de compactação............................................................... 37

Figura17. Ensaio de resistência à compressão dos briquetes............................ 39

Figura 18. Classificação granulométrica...................................................... 41

Figura 19. Perfis de carbonização.............................................................. 53

Figura 20. Perfis de carbonização.............................................................. 54 


\section{SUMÁRIO}

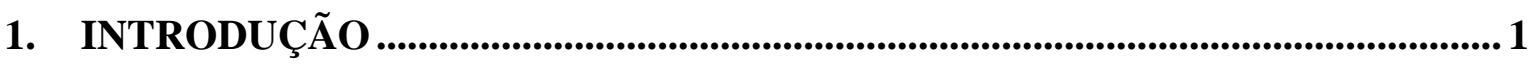

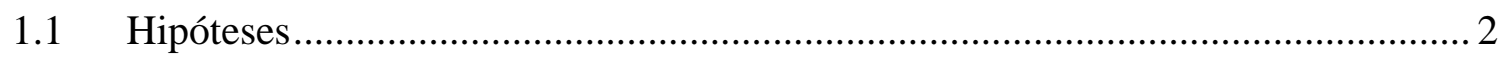

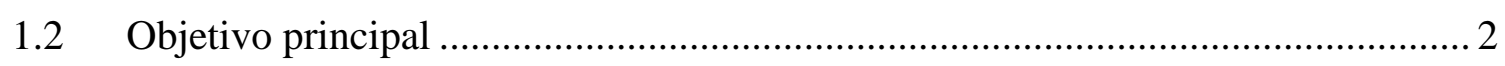

2. REVISÃO BIBLIOGRÁFICA .................................................................................... 3

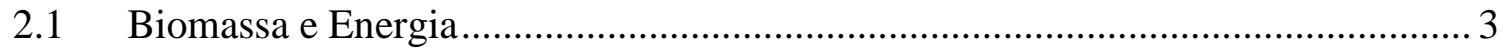

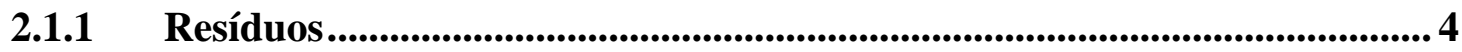

2.1.2 Resíduos do processamento da madeira ...................................................5

2.1.3 Resíduos do beneficiamento do Café (casca)................................................... 6

2.1.4 Resíduos do processamento do milho (Sabugo) ...........................................8

2.1.5 Resíduos da colheita do feijão (Palhada e vagem) ........................................9

2.2 Utilização energética dos resíduos .................................................................... 10

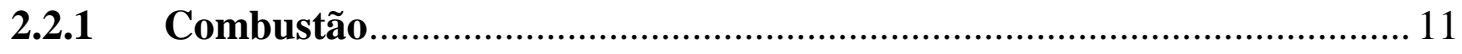

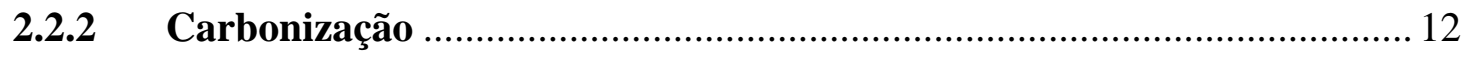

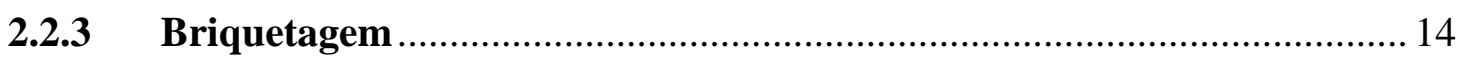

2.3 Propriedades físicas, químicas e energéticas ................................................... 16

2.3.1 Umidade, Densidade e Granulometria ................................................ 16

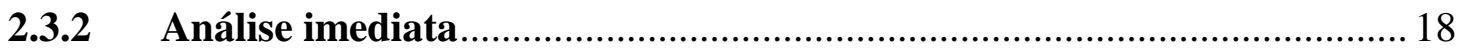

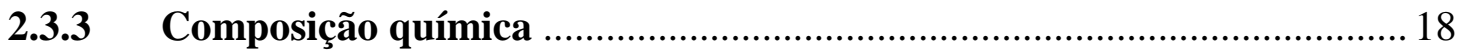

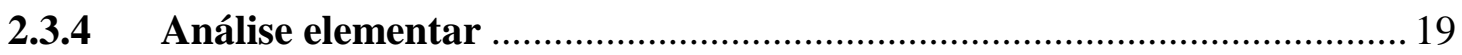

2.3.5 Poder Calorífico e densidade energética ................................................ 20

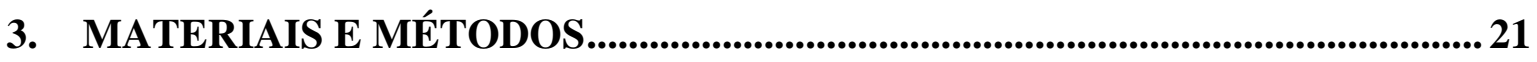

3.1 Caracterização das propriedades da biomassa in natura ......................................2 22

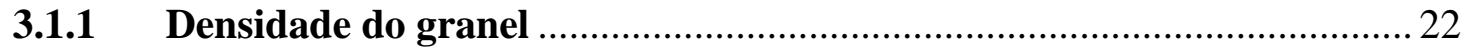

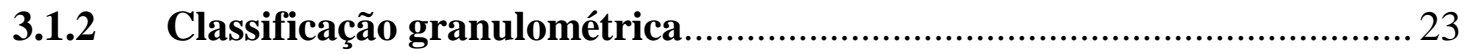

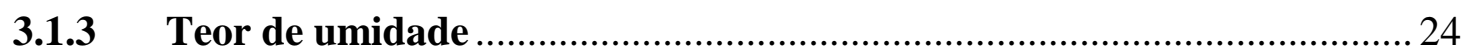

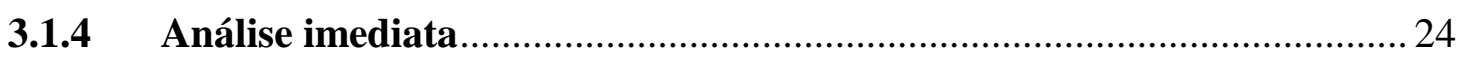

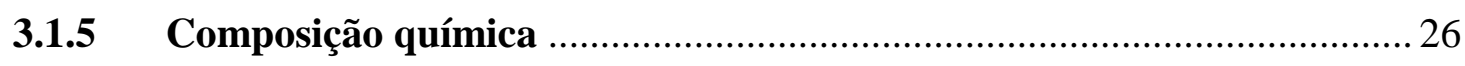

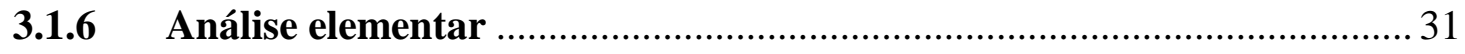

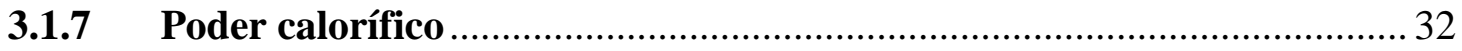

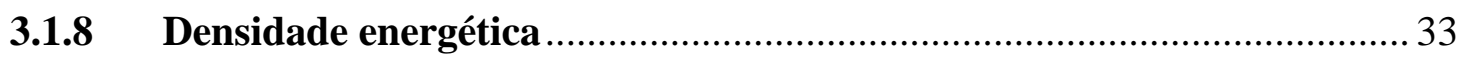

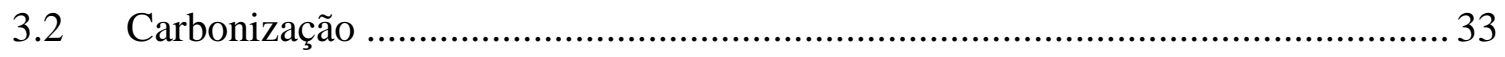




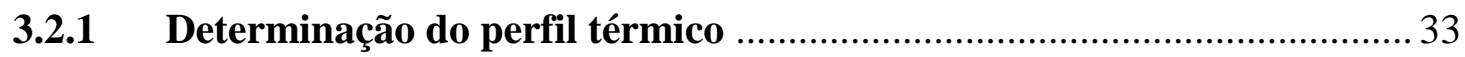

3.2.2 Definição do protocolo de carbonização .................................................. 34

3.2.3 Caracterização das propriedades do carvão ........................................... 35

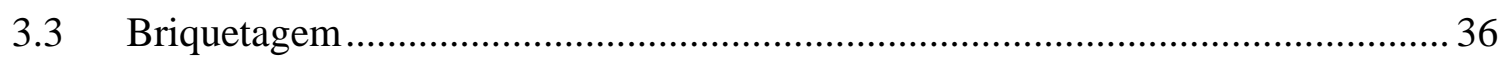

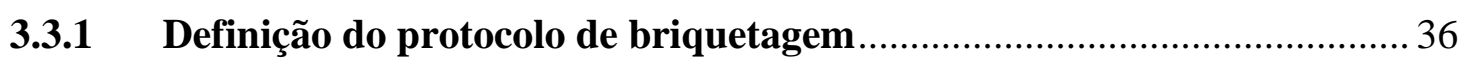

3.3.2 Avaliação das propriedades dos briquetes ............................................... 38

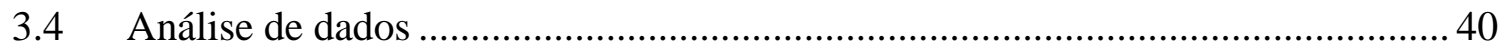

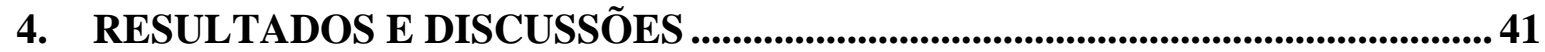

4.1 Caracterização das propriedades dos resíduos in natura ..................................... 41

4.1.1 Granulometria, teor de umidade e densidade do granel........................ 41

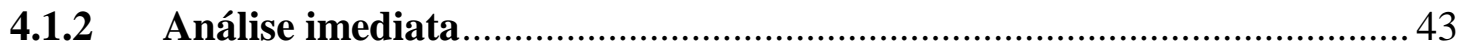

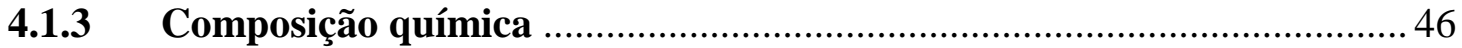

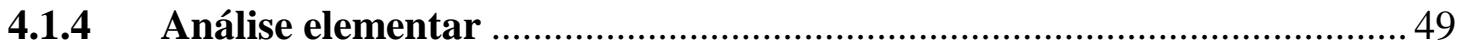

4.1.5 Poder calorífico e densidade energética........................................................ 50

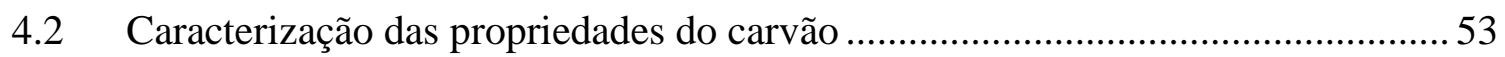

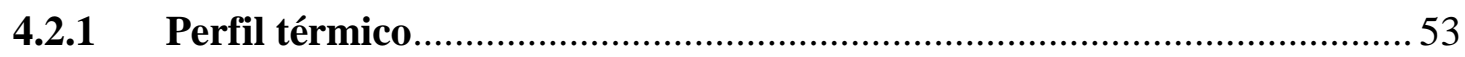

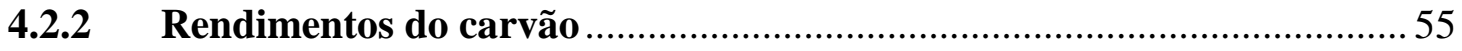

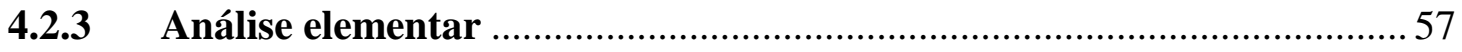

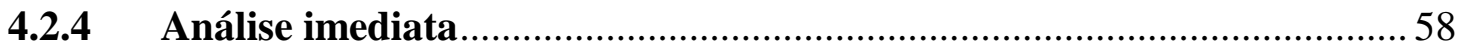

4.2.5 Poder calorífico, densidade do granel e densidade energética ................60 60

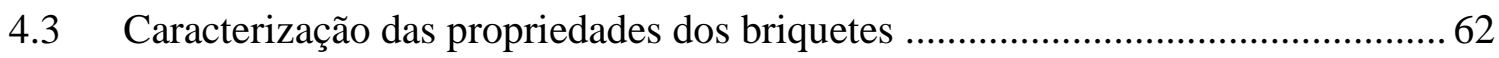

4.3.1 Teor de umidade, densidade aparente e resistência a compressão paralela 62

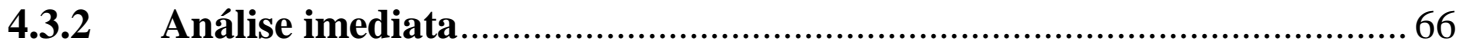

4.3.3 Poder Calorífico e Densidade Energética ................................................. 68

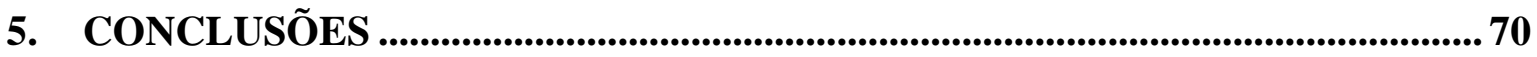

6. SUGESTÕES E RECOMENDAÇÕES PARA TRABALHOS FUTUROS.......... 71

REFERÊNCIAS BIBLIOGRÁFICAS ........................................................................ 72 


\section{INTRODUÇÃO}

A biomassa é formada a partir de espécies vivas e, por isto, é capaz de se reproduzir, sendo considerada renovável, o que a torna altamente atrativa como fonte de energia (BASU, 2010). Vegetais não-lenhosos, vegetais lenhosos (madeiras), resíduos provenientes da colheita ou do processamento de produtos agrícolas como cascas, bagaço e caroços, serragem, esterco, palhas, entre outros e biofluidos (óleos vegetais) são considerados fontes de biomassa (CORTEZ et al 2008).

A biomassa foi uma das primeiras fontes de energia utilizada pela humanidade (ANTAL Jr.; GRONLI, 2003), no entanto, o seu aproveitamento energético é limitado devido suas propriedades heterogêneas. Segundo Paula et al (2011) e Purohit et al. (2006) há vários motivos que levam à subutilização da biomassa, como, dimensões variadas, alta umidade, baixa densidade e grande volume, além de demandarem grandes áreas de estocagem e serem dispersos geograficamente, o que dificulta sua coleta e transporte. Contudo, estas desvantagens podem ser reduzidas pela pirólise e densificação.

Segundo a Agência Internacional de Energia (IEA, 2011) a previsão para o consumo mundial de energia é de um aumento de pelo menos um terço entre 2010 e 2035. Porém, ainda segundo dados da AIE, a previsão para 2050 é de redução de emissões de $\mathrm{CO}_{2}$ devido a substituição do uso dos combustíveis fósseis. No contexto nacional, aproximadamente $37 \%$ da oferta interna bruta de energia no Brasil foi proveniente de fontes renováveis, das quais $26 \%$, em relação ao total de energia consumida, correspondem à energia proveniente da biomassa (EPE, 2016). Assim, a diversificação da matriz energética e o uso de fontes renováveis tornam-se cada vez mais necessárias para suprir essa demanda.

Ohana (2012) afirma que é preciso encontrar possibilidades de usos para a biomassa com otimização da produção e geração de menores quantidades de resíduos, garantindo sua reciclagem industrial, reintegrando materiais residuais ao ciclo produtivo e evitando gastos com tratamento e disposição. Tais iniciativas incentivam o desenvolvimento de tecnologias limpas e o uso racional de matéria-prima natural, que constitui atualmente o grande desafio mundial para este milênio.

Existem várias opções para o aproveitamento dos resíduos, como exemplo pode-se citar a utilização deles como coberturas em granjas, nas indústrias de painéis de madeira reconstituída, na compostagem, na geração de energia pela queima direta, na produção de combustível sólido (carvão vegetal) ou na transformação dos resíduos em briquetes, entre 
outras possibilidades (QUIRINO, 2003), diminuindo assim os problemas ambientais relacionados com a contaminação do solo, ar, e água, por meio do descarte inadequado de resíduos agrícolas e florestais, e também reduzindo os custos de produção ou beneficiamento, agregando valor.

Nesse sentido, devido à crescente preocupação mundial de aumentar o uso de energia de fontes renováveis, os resíduos das mais variadas origens despontam-se como interessantes alternativas energéticas (PROTÁSIO et al., 2011; LYND et al., 2005; ZHANG et al., 2007). Por esta razão, os materiais lignocelulósicos, especialmente aqueles que resultam de resíduos agrícolas, de resíduos da agroindústria, de resíduos florestais e resíduos de papel, estão ganhando importância como recurso renovável de elevado potencial energético (MCKENDRY, 2002; XU et al., 2006; XU et al., 2009; ROSA et al., 2011).

Em virtude do exposto e do atual contexto energético mundial, o desenvolvimento contínuo de técnicas que visem a obtenção de novas fontes energéticas renováveis e o aumento da concentração energética, torna-se cada vez mais necessário.

\subsection{Hipóteses}

1. Resíduos agroflorestais podem ser aproveitados como fonte energética, densificados e carbonizados.

\subsection{Objetivo principal}

Avaliar o potencial energético de resíduos agroflorestais, visando a obtenção de produtos energéticos renováveis com maior valor agregado.

\section{Objetivos secundários}

1. Caracterizar a matéria prima residual produzida na colheita ou processamento de culturas agrícolas e florestais, in natura e carbonizada;

2. Analisar a possibilidade de utilização de aglutinantes produzidos a partir de dois resíduos agrícolas; quirela de milho e quirela de sorgo na produção de briquetes de carvão de resíduos agroflorestais.

3. Avaliar as características dos briquetes produzidos com os resíduos agroflorestais. 


\section{REVISÃO BIBLIOGRÁFICA}

\subsection{Biomassa e Energia}

As questões socioeconômicas (emprego, renda, fluxos migratórios) e ambientais (mudanças climáticas, nível de poluição), os preços crescentes dos combustíveis fósseis, combinados com o esgotamento das reservas dos mesmos, têm efeito direto no interesse pela utilização de fontes renováveis de energia, tais como solar, eólica, hidráulica, geotérmica e aquelas derivadas de biomassa (DIAS et al., 2012).

A biomassa é uma das fontes para a produção de energia com maior potencial de crescimento futuro. Tanto no mercado internacional quanto no interno, ela é considerada uma das principais alternativas para a diversificação da matriz energética e a consequente redução da dependência dos combustíveis fósseis (BRASIL, 2008). No Brasil esta tendência vem se consolidando a cada ano, como pode ser observado no gráfico da oferta interna de energia (Figura 1).

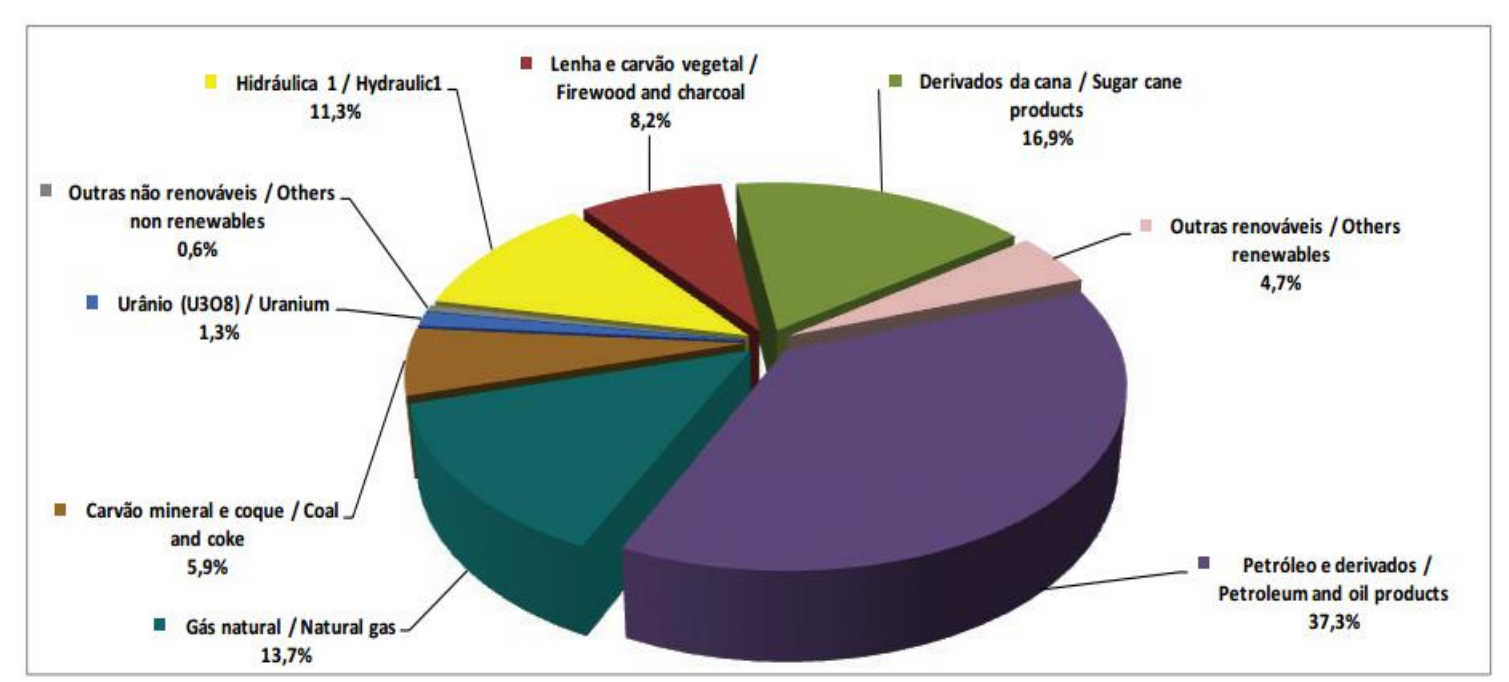

Figura 1. Oferta interna de energia (Fonte: EPE, 2016)

Os pontos mais importantes valorizados quando se trata da utilização da biomassa como fonte de geração de energia são os baixos teores de cinza e enxofre; serem combustíveis renováveis com possibilidade de uso nas formas líquida, sólida e gasosa; contribuírem para o balanço neutro entre emissões e fixação de gases poluentes como o dióxido de carbono; terem alta produtividade em regiões tropicais e subtropicais como o Brasil. São também pontos importantes o fato de poderem ser oriundas de plantios 
exclusivos para usos energéticos ou de plantios de usos múltiplos e de resíduos florestais, industriais e urbanos. O uso dos resíduos agroflorestais, facilita as operações posteriores de plantio ou replantio e reduz os riscos de incêndios e doenças nas próximas rotações. Além disso, sob o ponto de vista econômico, social e ambiental o uso da biomassa apresenta vantagens como o decréscimo da dependência das importações de petróleo; o aumento do uso dos recursos naturais e renováveis; melhoria no gerenciamento florestal e decréscimo nos custos energéticos (BENICIO, 2011).

\subsubsection{Resíduos}

O Brasil é um país com características favoráveis ao desenvolvimento de várias culturas agrícolas e florestais e, como consequência, tem uma grande geração de resíduos, proveniente tanto de atividades agrícolas quanto madeireiras, com grande potencial para aproveitamento energético em larga escala.

O termo resíduo, geralmente, é associado à ideia de lixo, porém, segundo Demajorivic (1995), resíduos sólidos diferenciam-se do termo lixo, pois este último não possui nenhum tipo de valor, referindo-se ao que deve ser descartado. Resíduos são aqueles que possuem valor econômico agregado, por possibilitarem seu reaproveitamento.

De acordo com Vale e Gentil (2008), resíduos podem ser definidos como todo o material que é descartado ao longo do processo produtivo, podendo o mesmo tornar-se um risco para o ambiente e para a sociedade. Porém, eles podem deixar de ser um risco e passar a gerar lucro, quando transformados em matéria prima para diversos outros processos, reduzindo os custos de produção do produto principal.

Segundo Eriksson e Prior (1990) os resíduos podem ser agrupados em três categorias:

a) Resíduos agrícolas, gerados diretamente no campo durante a colheita da safra (por exemplo: a palha dos cereais);

b) Resíduos florestais (galhos, folhas, etc., gerados na exploração florestal);

c) Resíduos agroindustriais, gerados no beneficiamento de grãos, raízes, gramíneas e madeira (casca de arroz, de café, de amendoim, de nozes, bagaço de cana, serragem, sabugo de milho, etc.)

Segundo Sater et al (2011) o grande volume de resíduos gerados pelas indústrias de transformação da madeira e pela agricultura é, ao mesmo tempo, uma oportunidade e um desafio, em praticamente todas as regiões do Brasil. 


\subsubsection{Resíduos do processamento da madeira}

A madeira é um insumo importante que vem se valorizando ao longo das últimas décadas, em função da ampliação da sua utilização e da escassez nas regiões tradicionalmente consumidoras. Porém, a utilização integral da madeira ainda não é uma realidade (RIBEIRO; MACHADO, 2005).

O setor florestal que engloba a indústria e a atividade silvicultural é complexo e amplo, sendo constituído de diversos segmentos de atividades e aplicações industriais e, por isto, cada estabelecimento que compõe o setor produz uma variedade de resíduos em grande quantidade, dificultando a quantificação precisa do montante de sobras geradas pelo processo produtivo, por não haver dados individualizados de produção de cada região (BORTOLIN, 2012; SCHNEIDER et al., 2012). A geração de resíduos do setor madeireiro está ilustrada na Figura 2.
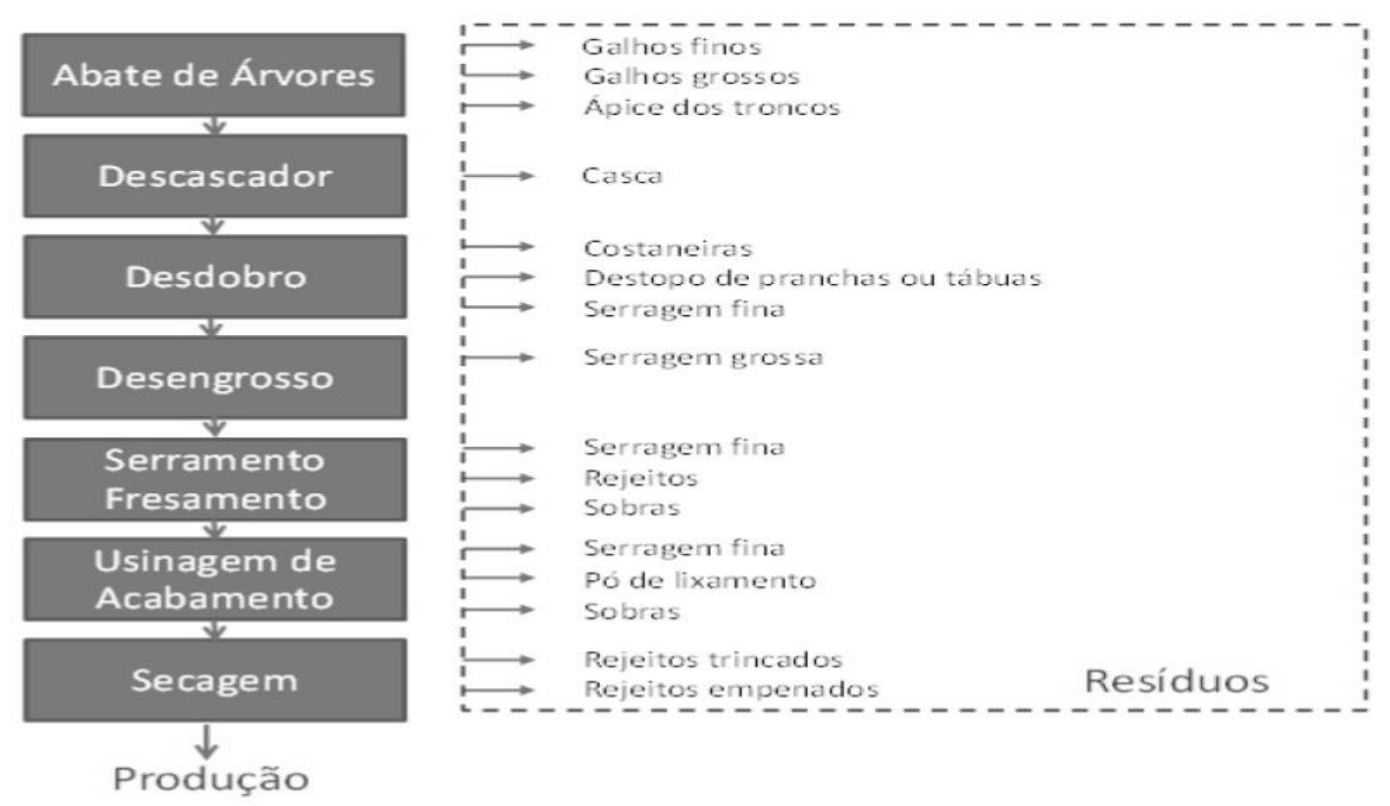

Figura 2. Etapas da industrialização e produção de resíduos de madeira. Fonte: Schneider et al.(2012)

De acordo com Gonçalves et al. (2009), a indústria madeireira tem a característica de gerar grandes volumes de resíduos durante o beneficiamento da madeira ou, mesmo, antes do processo propriamente dito. Se a madeira não atende às exigências do mercado consumidor, torna-se resíduo, juntamente com as serragens, as maravalhas, as costaneiras e as aparas. Segundo Ribeiro \& Machado (2005) somente $40 \%$ a $60 \%$ do volume total da 
tora é aproveitado no processamento em serrarias.

Segundo a pesquisa da Sociedade Brasileira de Silvicultura - SBS (2015), a produção de madeira em tora de florestas plantadas para uso industrial no Brasil, foi aproximadamente, 138 milhões de $\mathrm{m}^{3}$. Logo, cerca de 69 milhões de $\mathrm{m}^{3}$ de resíduos são produzidos.

O uso da biomassa florestal como insumo energético nas suas mais variadas formas de aproveitamento, vem adquirindo destaque no mercado energético, devido ao seu caráter renovável. Além deste caráter, os resíduos florestais apresentam como vantagens: descentralização da produção, redução de emissões atmosféricas, geração de oportunidade de trabalho no processo de produção, conservação energética e criação de novos mercados para as sobras florestais (OLIVEIRA et. al., 2013; SANTIAGO, 2013). Entretanto, o uso do material particulado apresenta desvantagens, como a exigência de adequação das caldeiras para uso de finos e dificuldades de transporte (DIAS, 2002).

Neste contexto, Rivela et al (2006) destaca que o aproveitamento de resíduos em produtos com maior valor agregado é uma interessante solução, não apenas para reduzir os impactos ambientais negativos, decorrentes da emissão de gases, como também para gerar trabalho e renda.

\subsubsection{Resíduos do beneficiamento do Café (casca)}

O Brasil é o maior produtor mundial de café, a produção da safra cafeeira (espécies arábica e conilon) em 2015 ficou em 2,6 milhões de toneladas e, segundo estimativas para a produção de 2016, após dois anos de produção baixa, a produção de café recupera-se, devendo alcançar 2,9 milhões de toneladas (IBGE, 2016).

Após a colheita, o beneficiamento do café pode ocorrer de duas formas: via seca ou via úmida. Segundo Vilela et al. (2001), no Brasil a forma mais comum de beneficiamento do café ocorre por via seca, no qual o fruto do café é seco ao sol ou em pré-secadores e secadores artificiais.

O fruto do cafeeiro é formado pelo grão (endosperma + embrião), que é envolvido por uma membrana transparente denominada tegumento, seguido pelo pergaminho (ou endocarpo), por uma camada de pectina (ou mucilagem), pela polpa (ou mesocarpo) e, finalmente, pela casca (ou pericarpo), conforme ilustrado na figura 3. 

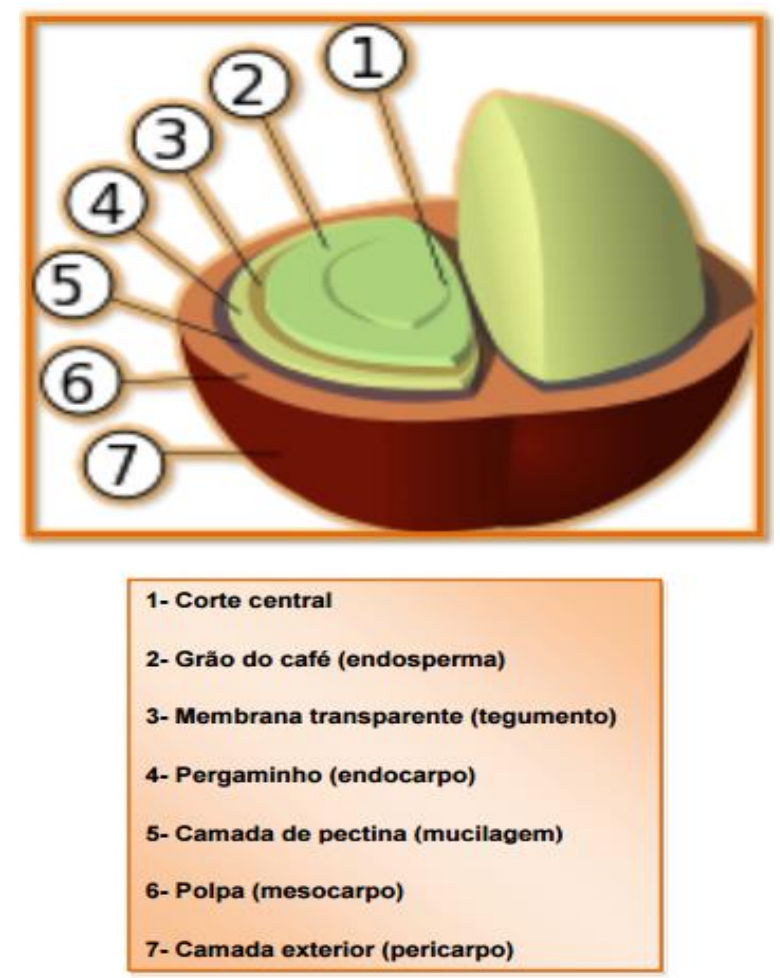

Figura 3. Estrutura do grão de café. Fonte: www.pedecafe.com

Após o despolpamento do fruto do café, denominado "Côco" ou "cereja", que é o grão de café que se encontra em pleno estágio de maturação, é separado o grão de café do endocarpo, mesocarpo, pericarpo e mucilagem; a esse conjunto, dá-se o nome de "palha de café", sendo esse o material objeto deste estudo. Carvalho (1992) e Rocha et al. (2006) afirmam que a relação entre a obtenção do grão beneficiado e o resíduo é de 1:1. A Tabela 1 apresenta a quantidade de café colhida em 2015 e o total de resíduos gerados.

Tabela 1. Quantidade de café colhida em 2015 e o total de cascas geradas.

\begin{tabular}{|c|c|c|c|}
\hline Região & Estado & $\begin{array}{l}\text { Produção de Grãos } \\
\text { (t) }\end{array}$ & $\begin{array}{c}\text { Produção de Cascas } \\
\text { (t) }\end{array}$ \\
\hline \multirow{4}{*}{$\begin{array}{l}\frac{0}{0} \\
0 \\
0 \\
0 \\
0 \\
0 \\
0 \\
0 \\
0\end{array}$} & MT & 7.175 & $3.587,5$ \\
\hline & MS & 1.333 & 666,5 \\
\hline & GO & 18.123 & $9.061,5$ \\
\hline & $\mathrm{DF}$ & 1.309 & 654,5 \\
\hline \multicolumn{2}{|c|}{ Subtotal região Centro-oeste } & 27.940 & 13.970 \\
\hline \multicolumn{2}{|c|}{ TOTAL GERAL BRASIL } & 2.645 .494 & 1.322 .747 \\
\hline
\end{tabular}

Fonte: grupo de coordenação de estatísticas agropecuárias - GCEA/IBGE (2016). 
Parte dos resíduos da polpação do café já é empregado em outros processos, tais como: adubação, por apresentar grande quantidade de potássio, nitrogênio e outros nutrientes, podendo ser utilizado na agricultura como excelente fonte de matéria orgânica, misturado a águas residuais de suinocultura como fertilizante composto e na alimentação de ruminantes, pois apresenta um alto nível de proteína bruta (VEGRO e CARVALHO 1994; COSTA et al., 2007; MATOS et al., 2007). Outra possibilidade é o uso energético com a queima direta, ou a partir da conversão em carvão, bioóleo, briquete ou pelete.

Vale et. al (2007) estudando a carbonização de resíduos do processamento do café, encontrou para casca o valor de poder calorífico superior de $3.933 \mathrm{kcal} / \mathrm{kg}$, e poder calorífico útil de $3.040 \mathrm{kcal} / \mathrm{kg}$, com $13,5 \%$ de teor de umidade; reafirmando a possibilidade da utilização deste resíduo em aparelhos de queima. Já Pereira (2006) informa o uso da casca do café na produção de briquetes para utilização em lareiras, fogões, churrasqueiras, fornalhas e secadores.

\subsubsection{Resíduos do processamento do milho (Sabugo)}

A produção do milho, um dos alimentos mais cultivados no Brasil, cresceu de 51 milhões de toneladas em 2009 para aproximadamente, 85 milhões de toneladas em 2015 (IBGE, 2016).

$\mathrm{Na}$ Tabela 2 são apresentados os valores de produção de grãos de milho e estimativa de resíduos gerados, para a região do centro-oeste e para o Brasil, referente à safra de 2015.

Tabela 2. Produção total de grãos de milho e resíduos - Safra 2015.

\begin{tabular}{|c|c|c|c|c|}
\hline Região & Estado & $\begin{array}{c}\text { Produção } \\
\text { (t) }\end{array}$ & $\begin{array}{c}\text { Resíduos } \\
\text { (talos }+ \text { folhas) } \\
\text { (t) }\end{array}$ & $\begin{array}{l}\text { Resíduos } \\
\text { (sabugo) } \\
\text { (t) }\end{array}$ \\
\hline \multirow{4}{*}{ 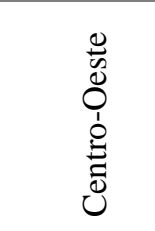 } & MT & 21.353 .295 & $52.315 .572,75$ & 12.811 .977 \\
\hline & MS & 9.727 .809 & $23.833 .132,05$ & $5.836 .685,4$ \\
\hline & GO & 9.512 .503 & $23.305 .632,35$ & $5.707 .501,8$ \\
\hline & $\mathrm{DF}$ & 528.188 & $1.294 .060,6$ & $316.912,8$ \\
\hline \multicolumn{2}{|c|}{ Subtotal região Centro-oeste } & 41.121 .795 & $100.748 .397,8$ & 24.673 .077 \\
\hline \multicolumn{2}{|c|}{ TOTAL GERAL BRASIL } & 85.282 .917 & $208.943 .146,7$ & $51.169 .750,2$ \\
\hline
\end{tabular}

Fonte: grupo de coordenação de estatísticas agropecuárias - GCEA/IBGE (2016). 
Como toda produção agrícola, a produção de milho gera grande quantidade de resíduos, os quais são deixados no campo e não são reaproveitados. Segundo Dias et al. (2012) a cultura do milho deixa como resíduos, no campo, os caules, as folhas e, na indústria, os sabugos. Estima-se que, para cada tonelada de grãos de milho colhida, geramse entre 2,2 e 2,7 toneladas de talos e folhas, bem como entre 0,3 e 0,9 toneladas de sabugos. Considerando a grande variação na produção de biomassa total da planta, influenciada pelas cultivares utilizadas e condições de manejo da cultura dentre as variedades em uso, há registros de produção de até 6 toneladas de resíduos por tonelada de grãos de milho.

\subsubsection{Resíduos da colheita do feijão (Palhada e vagem)}

O Brasil é o maior produtor mundial de feijão, comumente utilizado na alimentação do brasileiro, por ser reconhecidamente uma excelente fonte proteica (ABREU, 2005).

A produção de feijão em 2015 foi na ordem de 3 milhões de toneladas (IBGE, 2016). A Tabela 3 apresenta a quantidade de feijão colhido em 2015, o total de resíduos gerados e o total de resíduos que podem ser aproveitados para outros fins, como o energético.

Tabela 3. Produção de feijão, resíduos gerados e passíveis de serem aproveitados em 2015.

\begin{tabular}{|c|c|c|c|c|}
\hline Região & Estado & $\begin{array}{l}\text { Produção } \\
\text { (t) }\end{array}$ & $\begin{array}{c}\text { Resíduos gerados } \\
\text { (t) }\end{array}$ & $\begin{array}{c}\text { Resíduos aproveitados } \\
\text { (t) }\end{array}$ \\
\hline \multirow{4}{*}{ 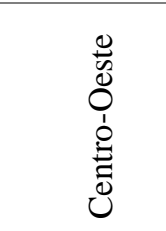 } & MT & 318.881 & $169.006,93$ & $67.602,772$ \\
\hline & MS & 27.057 & $14.340,21$ & $5.736,084$ \\
\hline & GO & 289.463 & $153.415,39$ & $61.366,156$ \\
\hline & DF & 33.496 & $17.752,88$ & $7.101,152$ \\
\hline \multicolumn{2}{|c|}{ Subtotal região Centro-oeste } & 668.897 & $354.515,41$ & $141.806,164$ \\
\hline \multicolumn{2}{|c|}{ TOTAL GERAL BRASIL } & 3.089 .823 & $1.637 .606,19$ & $655.042,476$ \\
\hline
\end{tabular}

Fonte: grupo de coordenação de estatísticas agropecuárias - GCEA/IBGE (2016).

Segundo o Schneider et al. (2012), os principais resíduos do feijão são constituídos de palhada e vagem, totalizando um fator residual de 53\% sobre o total produzido. Com este coeficiente técnico, estima-se que a quantidade de resíduos gerados foi de 1.637 .606 toneladas na safra 2015. Ressalta-se que, a princípio, parte dos resíduos de feijão deve permanecer no campo. Como planta fixadora de nitrogênio, os resíduos são ricos neste 
elemento, que deve ser prioritariamente mantido no próprio local de produção para condicionamento do solo (MAGALHÃES, 2005). Segundo a Empresa de Pesquisa Energética (EPE,2014), recomenda-se que 60\% da palha de feijão permaneçam no solo, ou seja, $40 \%$ destes resíduos podem ser aproveitados para outro fim, como o energético.

\subsection{Utilização energética dos resíduos}

Resíduos de biomassa, como os provenientes das atividades agrícolas (casca de cereais, resíduos resultantes da colheita do trigo, arroz, algodão, milho, café, soja, etc.) ou das atividades florestais (cascas, folhas, restos da colheita e poda, cepas, lenha, resíduos do desdobro mecânico em serrarias e outros), devido ao seu baixo custo e pronta disponibilidade, representam uma alternativa energética viável (VALE et al., 2000; SANTIAGO \& ANDRADE, 2005). Contudo, para que esta vantagem seja aproveitada, é necessário manejo correto dos resíduos, desenvolvimento científico e tecnológico.

Segundo Quirino (2003), ao valorizar o resíduo torna-se possível a eliminação de despesas, além de possibilitar uma renda a mais para a indústria geradora, agregando valor à produção. Um resíduo lignocelulósico pode ser reciclado e transformado e utilizado como matéria prima para conversão em outro produto diferente daquele de origem. Os mesmos podem também ser utilizados energeticamente na produção de calor, de vapor, ou sob a forma de combustível sólido, como o carvão vegetal.

$\mathrm{O}$ potencial de resíduos de biomassa para atender às necessidades de energia tem atraído o interesse de diversos pesquisadores nos últimos tempos. Por exemplo, Fernandes Costa (2010) avaliaram o potencial energético de resíduos agrícolas e florestais na província de Marvão na Espanha e encontraram um potencial anual de 160Tj. Vasco e Costa (2009) avaliaram o potencial energético dos resíduos florestais na província de Maputo em Moçambique, e relataram que os resíduos podiam substituir cerca de $32 \%$ das necessidades energéticas de 2004 na província. Outros exemplos de estudos sobre potencial energético dos resíduos de biomassa foram realizados a nível nacional no Zimbabwe, (SHONHIWA, 2013), e na Roménia, (SCARLAT et al., 2005). Os critérios de avaliação do potencial energético da biomassa são propriedades físico-químicas; energia útil disponível; custo da tonelada de matéria orgânica seca; os tipos e quantidades de resíduos sólidos e efluentes gasosos produzidos após o uso da biomassa e principalmente o teor de umidade (PÉREZ, 2010).

Segundo dados Associação brasileira das indústrias de biomassa e energia 
renovável (ABIB, 2010), no Brasil existe uma grande disponibilidade de resíduos florestais (70 milhões de toneladas), e não florestais como: casca de arroz, café, resíduos de coco, milho, feijão, cacau e muitos outros que podem ser convertidos em biomassa para geração de energia. Ainda segundo dados da Associação, estima-se que o potencial total a ser explorado de energia primária resultante da biomassa residual envolvendo apenas os resíduos vegetais no País é de 10.084,96 milhões de GJ/ano (gigajoule por ano).

Houve muitas tentativas para estimar a produção e o uso dos resíduos globais, mas todas apresentaram muitas variações, pela existência dos diferentes usos alternativos e também pela necessidade de se determinar o que é e o que não é um resíduo reutilizável para obtenção de energia (CORTEZ et al., 2008).

\subsubsection{Combustão}

A combustão é a queima de materiais carbonosos na presença de oxigênio suficiente para completar o processo (SORENSEN, 2004). Ocorre geralmente em fogões (cocção de alimentos), caldeiras (geração de vapor) e altos fornos (metalurgia). Segundo Brito e Barrichelo (1979) a combustão completa produz dióxido de carbono $\left(\mathrm{CO}_{2}\right)$, vapor d'água, juntamente com chama, calor e cinzas. Quando a combustão é incompleta ocorre a formação de monóxido de carbono $(\mathrm{CO})$, hidrocarbonetos e outros gases. A combustão completa do carbono (C) ocorre como segue a equação 1 , na proporção de $1 \mathrm{C}$ para 3,66 $\mathrm{CO}_{2}$.

$$
\begin{gathered}
\mathrm{C}+\mathrm{O}_{2} \rightarrow \mathrm{CO}_{2}+\Delta(\text { Equação } 1) \\
1+2,66
\end{gathered}
$$

Uma boa combustão deve liberar a energia do combustível com um mínimo de perdas devido à combustão incompleta, seja por falta ou excesso de ar, umidade do combustível, processo de turbulência e mistura do ar durante a operação, e outros. Segundo Lopes et al. (2003) para que a combustão ocorra eficientemente são necessários os três "T" da combustão: temperatura alta o suficiente para iniciar e manter a queima do combustível; mistura ou turbulência adequada do ar com o combustível; tempo suficiente para a ocorrência da reação de combustão.

Todavia, o processo de combustão direta normalmente apresenta baixos rendimentos, em função da baixa eficiência dos aparelhos de queima. A maioria das 
fornalhas a lenha não dispõem de mecanismo de controle do processo de combustão. Essas fornalhas requerem supervisão constante do operador e, na maioria das vezes, são operadas inadequadamente. O manejo inadequado de fornalhas favorece a combustão incompleta, a contaminação do produto por resíduos da combustão presentes no ar de secagem e, dificuldades para a manutenção constante da temperatura do ar durante a secagem.

O controle da combustão tem por objetivo assegurar a mistura eficaz do comburente e combustível na dosagem correta, no tempo certo e na temperatura ideal, de modo a garantir a queima completa do mesmo, ou seja, a liberação de toda energia contida no combustível (LOPES et al., 2003). Na indústria este controle é feito por meio de instrumentos que monitoram a qualidade dos gases de combustão. Sensores instalados na câmara de combustão e na saída dos gases de combustão, controlam a entrada de ar e a dosagem de combustível de modo a garantir as condições necessárias a uma boa combustão. Os principais parâmetros envolvidos neste controle são o excesso de ar e a temperatura de combustão.

Algumas das características que fazem da biomassa um bom combustível são a facilidade de secagem, elevado poder calorífico, baixa temperatura de ignição, elevado teor em voláteis (Werther et al., 2000), elevada taxa de combustão (Kanury, 1994) e baixa energia de ativação (Tabarés et al., 2000). Estas propriedades são influenciadas tanto pelas características do combustível como pelas características da fornalha (KANURY, 1994).

Vários pesquisadores, dentre eles Gomes (1988), Saglietti (1991), Valarelli (1991), Oliveira (1996) e Silva e Silva (1998), cientes do consumo excessivo de energia e do baixo rendimento apresentado pelas fornalhas comumente empregadas na secagem de grãos, estudaram novas concepções de fornalhas, mais eficientes e econômicas. Entretanto, apesar destes esforços, não se encontrou na literatura consultada estudos de mecanismos de baixo custo ou de metodologias que orientam os operadores de fornalhas a operá-las de forma otimizada, de modo a aproveitar ao máximo a energia do combustível.

\subsubsection{Carbonização}

O Brasil é hoje o maior produtor e consumidor mundial de carvão vegetal, com aproximadamente 3.901.000 de toneladas/ano, segundo o Balanço Energético Nacional de 2016 (EPE, 2016). Este insumo energético, além de ser amplamente utilizado pela siderurgia brasileira como termo redutor ou redutor, é consumido nas indústrias cerâmicas, cimenteira, alimentícia a também no setor doméstico. 
O carvão é uma fonte secundária de energia produzida a partir da pirolise (ou carbonização) da madeira, em temperaturas acima de $250^{\circ} \mathrm{C}$, na ausência ou na presença de quantidades controladas de oxigênio atmosférico (ANTAL; GRONLI, 2003; SYRED et al., 2006; TRUGILHO; SILVA, 2001).

Segundo Rezende (2006), o processo de carbonização ocorre em quatro fases:

- Fase I - Secagem: ocorre até $110^{\circ} \mathrm{C}$ quando apenas a umidade é liberada;

- Fase II - Torrefação: ocorre entre $110^{\circ} \mathrm{C}$ e $250^{\circ} \mathrm{C}$, sendo que na temperatura de $180^{\circ} \mathrm{C}$ tem início à liberação da água de constituição pela decomposição da celulose e hemicelulose e pouco peso é perdido até $250^{\circ} \mathrm{C}$;

- Fase III - Carbonização: ocorre entre $250^{\circ} \mathrm{C}$ e $350^{\circ} \mathrm{C}$ com a intensificação da decomposição da celulose e hemicelulose ocorre expressiva perda de peso, formando-se gás, óleo e água. Ao atingir a temperatura de $350^{\circ} \mathrm{C}$ o carvão tem $75 \%$ de carbono fixo e se considera que a carbonização está praticamente pronta;

- Fase IV - Fixação: dos $350^{\circ} \mathrm{C}$ em diante ocorre redução gradual na liberação dos voláteis, principalmente gases combustíveis, continuando a fixação do carbono.

Os estágios da temperatura determinam o início e o fim de cada fase e o limite é a $500^{\circ} \mathrm{C}$, quando o processo atinge a melhor relação entre o rendimento em massa e o teor de carbono fixo e após essa faixa inicia-se o processo de gaseificação (ANTAL, 2003).

Os principais produtos da pirólise de biomassas são os materiais voláteis de baixo peso molecular (gases), alcatrões (líquido) e carvão (sólido) e as suas formações são dependentes da temperatura, da razão de aquecimento, do tamanho da partícula e da presença ou ausência de um catalisador. Os produtos formados através desse processo podem ser utilizados como combustíveis devido ao seu elevado poder calorífico (OUNAS et al., 2011).

O carvão vegetal é um produto concentrado em carbono, com baixo teor de voláteis e isento de umidade. É um material bastante reativo, ou seja, reage com gases que contenham oxigênio, sendo uma das principais razões para sua larga aplicação no setor siderúrgico (MATARELLI et al, 2001). A biomassa mais utilizada, atualmente, para produção de carvão vegetal é a lenha, entretanto estudos indicam outras fontes de matéria prima para a produção como os resíduos agrícolas e florestais.

No reaproveitamento dos resíduos, como na pirólise da matéria-prima, o que era resíduo transformar-se-á em energia, ajudando, assim, na preservação da natureza e na economia de energia (SATER et al., 2011). 


\subsubsection{Briquetagem}

Briquetagem é um processo em que pequenas partículas de materiais são prensadas para formar blocos de forma definida e de maior tamanho. Por meio desse processo, subprodutos de beneficiamento agroflorestal e finos de carvão convertem-se em um material de maior valor comercial (ANTUNES, 1982).

Para a briquetagem de biomassa in natura, o processo mais usual é realizado em elevadas pressões, que provoca um aumento da temperatura do processo da ordem de $100^{\circ} \mathrm{C}$, o que faz com que a lignina atue como ligante das partículas da biomassa vegetal. Nesse processo, é importante que o teor de umidade esteja entre $8 \%$ e $15 \%$ e o tamanho da partícula esteja entre 5 e $10 \mathrm{~mm}$ (MORAIS et al., 2006). Esse processo também pode ser utilizado para biomassa carbonizada, contudo, segundo Fontes et al. (1984) na produção de briquetes de carvão vegetal, usa-se um aglutinante (cola) para promover a união das partículas.

Segundo Moro (1987), uma metodologia típica para a briquetagem de finos de carvão deve consistir nas seguintes etapas:

- Moagem do carvão: a moagem é necessária para evitar partículas muito grandes que prejudiquem a ação dos materiais ligantes. Normalmente, são utilizados moinhos de martelo e

- Mistura com o aglutinante: o aglutinante é um material que tem a função de unir as partículas do carvão. A escolha do tipo e da quantidade de aglutinante é o ponto mais crítico na manufatura dos briquetes, sendo a etapa mais sensível aos custos do processo;

- Prensagem: a briquetagem propriamente dita resulta da aplicação de pressão, em que prensas sobre a massa do carvão fazem com que o briquete adquira resistência e formato geométricos definidos.

- Secagem: alguns ligantes são adicionados com água ao briquete, proporcionando uma umidade alta ao produto final. Por esse motivo eles devem ser secos, o que geralmente é conseguido com a passagem de ar quente em uma estufa.

- Estocagem e embalagem: os briquetes são armazenados em silos de estocagem dimensionados para manter um estoque intermediário entre a produção e a distribuição. Em seguida, são empacotados para consumo. Um fluxograma da produção de briquetes de finos carvão vegetal é apresentado na Figura 4. 
Moagem e classificação

da moinha

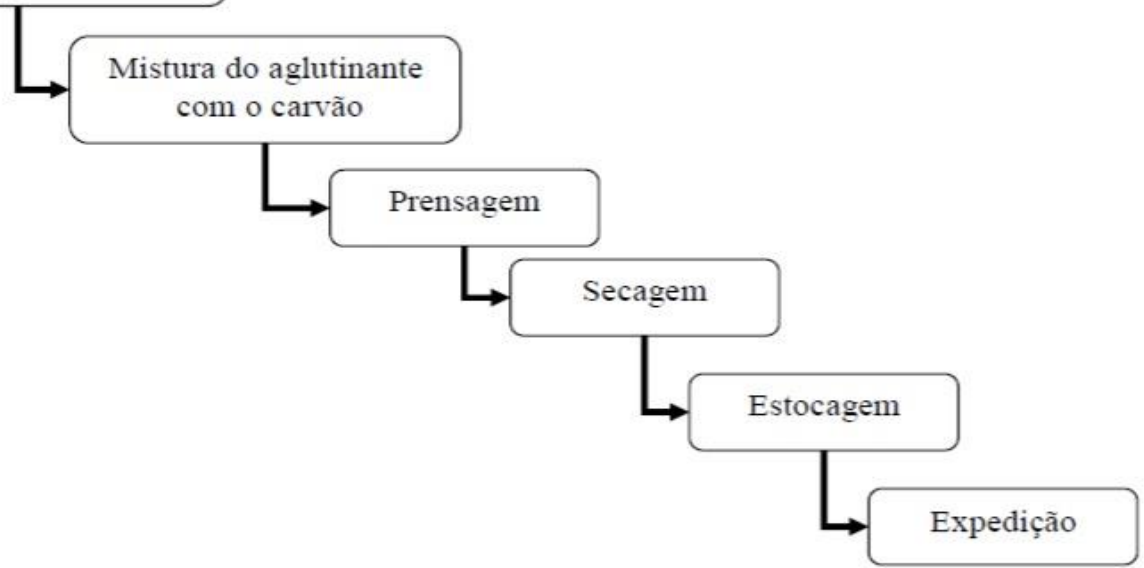

Figura 4. Fluxograma de briquetes de finos de carvão vegetal. Fonte: Melo (2000)

Pela briquetagem do carvão vegetal, consegue-se um combustível com homogeneidade granulométrica, maior densidade e resistência à geração de finos. O efeito de densificação proporcionado pela briquetagem produz um combustível com maior concentração energética por unidade de volume, que, aliado à resistência adquirida, viabiliza técnica e economicamente o transporte a distâncias maiores (FONTES et al. 1984). Segundo Quirino \& Brito (1991) um mesmo volume de briquetes pode ter cinco vezes mais energia que a madeira in natura. Outra grande vantagem da briquetagem é a possibilidade de aproveitamento de resíduos lignocelulósicos carbonizados em geral.

Segundo Furtado et al. (2010) as características que qualificam um briquete são elevados poder calorífico superior (PCS), densidade aparente e resistência à compressão. Estas características são influenciadas por variáveis relacionadas ao processo de produção. O poder calorífico superior indica o potencial de produção de energia por unidade de massa; a densidade, expressa a quantidade de material por unidade de volume. Portanto, quanto maior o poder calorífico e maior densidade do briquete, mais concentrada a energia estará e maior será o potencial energético do combustível. Além deste potencial outra variável importante é a carga máxima à compressão, que define a resistência do briquete durante o transporte e o armazenamento.

- Utilização de aglutinantes no processo de briquetagem

O estudo do melhor material ligante é de fundamental importância no processo de briquetagem. A escolha do tipo e da quantidade de aglutinante é o ponto mais crítico na 
manufatura dos briquetes, o aglutinante não deve prejudicar as características energéticas do carvão, diminuindo o rendimento calorífico, aumentando o teor de voláteis e cinzas, ou mesmo, ser usado em proporções que seu gasto inviabilize economicamente o briquete (FONTES et al., 1984; MARSOLLA, 1998).

Os aglutinantes podem ser classificados em três tipos: matriz, filme e químico.

- Aglutinantes tipo matriz - formam uma matriz contínua, envolvendo completamente as partículas. São exigidas quantidades razoáveis do aglutinante porque, geralmente, as substâncias são pouco resistentes e dependem de uma fase contínua em torno das partículas individuais. Ex: alcatrão vegetal e mineral, asfalto ou piche de petróleo;

- Aglutinantes tipo filme - são usados geralmente como soluções ou dispersões, como o álcool, a acetona, o tetracloreto de carbono, entre outros, porém a água se destaca como o solvente mais comum. Quando úmidos, os briquetes apresentam baixa resistência, e quando secos observa-se alta resistência. No caso de materiais orgânicos ou produtos celulares, a água estimula a adesão pelas forças de Van der Waals, devido ao aumento da área verdadeira de contato entre partículas. Ex: silicato de sódio, água, amido, melaço, os lignosulfatos e outros, e

- Aglutinantes químicos - são aqueles aglutinantes que dependem de reações químicas efetivas dos componentes do aglomerado entre si ou entre o aglutinante e o material que está sendo aglomerado. Os aglutinantes químicos podem ser do tipo matriz ou filme, dependendo, principalmente, da resistência e das características dos produtos das reações. Ex: $\mathrm{Ca}(\mathrm{OH})_{2}+$ melaço; $\mathrm{Ca}(\mathrm{OH})_{2}+\mathrm{CO}_{2} \mathrm{MgO}+\mathrm{Fe}_{2} \mathrm{O}_{3}$; silicato de sódio $+\mathrm{CO}_{2}$; e outros (PIETSCH, 1976, citado por QUIRINO, 1991).

As principais características dos aglutinantes são: alta taxa de aglomeração; inexistência de material inerte em sua composição; disponibilidade; alta resistência mecânica; resistência à umidade e boas condições de operacionalidade (SALEME, 1992).

Não obstante as reconhecidas vantagens do briquete de carvão vegetal, esta atividade industrial é pouco praticada e pouco pesquisada, principalmente no que diz respeito aos aglutinantes.

\subsection{Propriedades físicas, químicas e energéticas}

\subsubsection{Umidade, Densidade e Granulometria}

O teor de umidade é definido como a massa de água contida na biomassa e pode ser 
expressa tanto na base úmida (bu) quanto na base seca (bs), portanto, na apresentação de resultados de umidade, é necessário expressar em que base foi feito o cálculo (NOGUEIRA e RENDEIRO, 2008).

O teor de umidade é fator determinante para outras propriedades como densidade, estabilidade dimensional, resistência e exerce grande influência sobre o poder calorífico do combustível (SOUZA, 2010) e na densidade energética. Isso ocorre, pois, parte da energia produzida durante o processo de combustão é consumida na vaporização da água correspondente à umidade do material, ficando indisponível para qualquer utilização energética posterior (CARVALHO, 2011). Além disso, Garcia (2010) também afirma que elevados teores de umidade acarretam perdas de energia, baixa ignição e durabilidade, além de menor tempo de estocagem.

A densidade ou massa específica é outra propriedade relevante, exprime a quantidade de massa contida num determinado volume de material e é de grande importância para a caracterização da biomassa (SILVA, 2001). A densidade é comumente expressa pela densidade básica, que consiste da relação entre a massa seca a $0 \%$ de umidade do material e o seu volume saturado, entretanto a metodologia de determinação da densidade pode variar em função do tipo de biomassa.

Quando a determinação é realizada pelo método a granel, onde um recipiente de volume conhecido é preenchido com o material a ser analisado, a densidade sofre, além da influência do teor de umidade, da granulometria das partículas, pois quanto menor o tamanho das partículas, maior será a acomodação destas no recipiente, resultando em maior massa e, consequentemente, maior massa específica aparente a granel (BRAND, 2010).

Ensaios realizados por Pinheiro et al., (2006) indicaram que o parâmetro que influenciou de maneira mais expressiva a densidade energética dos resíduos vegetais estudados foi a densidade a granel dos mesmos, com ressalvas ao teor de umidade.

Fontes (1994) frisou a importância das dimensões das partículas de madeira (cavacos e serragem) para atividades como manuseio, armazenagem, transporte e eficiência da queima, visto que as partículas mais finas podem ser queimadas em suspensão e os resíduos maiores devem ser queimados em grelhas.

Por meio do teste de granulometria obtêm-se frações em peso de cada dimensão característica dos sólidos que compõem a biomassa. A análise granulométrica da amostra de partículas é classicamente realizada utilizando-se um sistema de peneiras padronizado 
(SÁNCHEZ et al., 2010).

Segundo Kanury (1994) características como a umidade, granulometria, densidade e heterogeneidade dos materiais lenhosos podem limitar a eficiência da combustão.

\subsubsection{Análise imediata}

A análise imediata fornece os teores materiais voláteis, cinzas e, por diferença, o carbono fixo. Cardoso (2010) os define como substâncias que se desprendem da madeira como gás. Os materiais voláteis estão relacionados com o comportamento do combustível na decomposição térmica, pois determina a facilidade com que a biomassa queima (CARASCHI et al., 2012). O teor de materiais voláteis pode contribuir para a baixa eficiência energética durante a queima da biomassa (CHAVES et al., 2013).

As cinzas são substâncias inorgânicas que não entram em combustão, como o silício $(\mathrm{Si})$, potássio $(\mathrm{K})$, sódio $(\mathrm{Na})$, enxofre $(\mathrm{S})$, cálcio $(\mathrm{Ca})$, fósforo $(\mathrm{P})$, magnésio $(\mathrm{Mg})$ e ferro (Fe) (KLAUTAU, 2008).

O teor de carbono fixo pode ser definido como a quantidade de carbono presente na biomassa (MOERS et al., 2011), excetuando o carbono nos materiais voláteis. É a massa remanescente após a liberação dos voláteis (SANTOS, 2009). A lignina é o principal componente químico responsável pela presença de carbono fixo, que contribui para a liberação de energia durante o processo de queima direta (CASTRO, 2011). Segundo Assis (2008), no carvão vegetal, o teor de carbono fixo depende do teor de lignina na biomassa, portanto de sua qualidade e do processo de carbonização. Chaves et al. (2013), afirmam que o carbono fixo tem uma relação direta com o poder calorífico, ou seja, quanto maior o teor de carbono fixo maior o conteúdo energético.

\subsubsection{Composição química}

O conhecimento da composição química (teor de celulose, hemicelulose e lignina) da madeira e de outras biomassas é um fator importante para a avaliação do rendimento energético de um processo de combustão, carbonização ou para a viabilidade na utilização de biomassas em processos de compactação (COUTO et al., 2004).

Sabe-se que cada biomassa tem proporções distintas dos seus constituintes químicos básicos: a celulose, hemicelulose e lignina. Para a utilização energética da biomassa são preferíveis espécies com maiores teores de lignina, pois este componente 
químico é o menos degradado termicamente (CETEC, 1980). A madeira é um material bastante heterogêneo, cuja proporção aproximada de celulose, hemicelulose e lignina é, respectivamente, 50:20:30. Os demais componentes da madeira, presentes em menor quantidade, são compostos de baixo peso molecular e são chamados de extrativos, sendo encontrados principalmente na casca, geralmente formados por terpenos, óleos essenciais, resinas, fenóis, taninos, graxas e corantes (PHILIPP, 1988).

\subsubsection{Análise elementar}

Pela análise elementar são determinados os teores de carbono $(\mathrm{C})$, hidrogênio $(\mathrm{H})$, oxigênio $(\mathrm{O})$, nitrogênio $(\mathrm{N})$, enxofre $(\mathrm{S})$ e cinzas dos materiais, dos quais os elementos de maior contribuição para o poder calorífico são o carbono e o hidrogênio, neste sentido quanto maior a quantidade destes elementos, mais energético será o material (VALE; GENTIL, 2008).

A análise química elementar da madeira mostra que, sem considerar as quantidades mínimas de nitrogênio e de outros elementos, como o enxofre, esta é constituída, aproximadamente, por $50 \%$ de carbono, $6 \%$ de hidrogênio e $44 \%$ de oxigênio. Independente da espécie, das diferenças genéticas ou da idade, essa composição se mantém aproximadamente constante (Penedo, 1980).

Lora (1997), estudando as perspectivas da utilização da biomassa para fins energéticos, apresentou a composição elementar da madeira de eucalipto, comparando-a com outras biomassas, conforme pode ser visto na Tabela 4.

Tabela 4- Análise elementar.

\begin{tabular}{lccccc}
\hline \multirow{2}{*}{ Tipo de biomassa } & \multicolumn{5}{c}{ Composição elementar $(\%)$} \\
\cline { 2 - 6 } & $\mathrm{C}$ & $\mathrm{H}$ & $\mathrm{O}$ & $\mathrm{N}$ & $\mathrm{S}$ \\
\hline Eucalipto & 49,00 & 4,87 & 43,79 & 0,30 & 0,01 \\
\hline Pinho & 49,29 & 4,99 & 44,36 & 0,06 & 0,03 \\
\hline Casca de arroz & 40,96 & 4,30 & 34,86 & 0,40 & 0,02 \\
\hline Bagaço de cana & 44,80 & 4,35 & 39,55 & 0,38 & 0,01 \\
\hline Casca de coco & 48,23 & 4,23 & 33,19 & 2,98 & 0,12 \\
\hline Sabugo de milho & 46,58 & 4,87 & 44,46 & 0,47 & 0,01 \\
\hline Ramas de algodão & 47,05 & 4,35 & 40,97 & 0,65 & 0,21 \\
\hline
\end{tabular}

Fonte: Lora (1997). 
Segundo Brito et al. (1979) a composição química elementar é um importante parâmetro quando o objetivo é o uso da biomassa como fonte de energia.

\subsubsection{Poder Calorífico e densidade energética}

O poder calorífico é uma propriedade importante na avaliação de um combustível sólido e representa a quantidade de calor liberada pela combustão completa de uma unidade de massa de um combustível (ÇENGEL; BOLES, 2006; SOARES et al., 2006) e é expresso em $\mathrm{cal} / \mathrm{g}$ ou $\mathrm{kcal} / \mathrm{kg}$ e pelo sistema internacional $\mathrm{j} / \mathrm{g}$ ou $\mathrm{kj} / \mathrm{kg}$. O poder calorífico é subdividido em superior, inferior e útil.

O poder calorífico superior (PCS) desconsidera as perdas de energia com a evaporação da água presente no combustível (DEZAJACOMO, 2010), isto é, ele quantifica a quantidade de calor liberada pela queima de modo que a água proveniente da combustão esteja em estado líquido, ou seja, que o calor latente de vaporização da água de constituição seja recuperado (SANTOS, 2009; GARCIA, 2010; SILVA, 2012). Já o poder calorífico inferior é a energia efetivamente disponível por unidade de massa de combustível após deduzir as perdas com a evaporação da água (JARA, 1989).

O poder calorífico útil (PCU) é a quantidade de calor liberado pela queima, com a água em seu estado gasoso, sendo descontada a energia necessária para evaporar a água referente à umidade da madeira (LIMA, 2010). Segundo Couto et al. (2004) esta é uma das propriedades mais importantes com relação à geração de energia a partir de materiais renováveis.

A densidade energética está relacionada à energia contida num determinado volume de biomassa e é obtida pelo produto entre o poder calorífico ( $\mathrm{kcal} / \mathrm{kg}$ ) e a densidade da biomassa $\left(\mathrm{kg} / \mathrm{m}^{3}\right)$. Para utilização energética dos combustíveis de biomassa é desejável alta densidade energética, ou seja, a maior quantidade de energia por unidade de volume (GARCIA et al., 2012; PROTÁSIO et al., 2012). 


\section{MATERIAIS E MÉTODOS}

A biomassa utilizada foi composta por materiais residuais da colheita ou processamento de diferentes culturas agrícolas e florestais. As amostras foram coletadas durante a safra de 2015 e 2016 . Na Tabela 5 estão listadas as matérias primas utilizadas no trabalho.

Tabela 5. Matérias primas utilizadas.

\begin{tabular}{|c|c|c|}
\hline \multicolumn{2}{|c|}{ RESÍDUOS } & LOCAL DE COLETA \\
\hline $\begin{array}{c}\text { Café } \\
(\text { Coffeaarabica } \mathrm{L})\end{array}$ & Casca de café & $\begin{array}{c}\text { Indústria Café do Sítio } @ \text {, em } \\
\text { Varginha/MG. }\end{array}$ \\
\hline $\begin{array}{c}\text { Feijão } \\
\text { (Phaseolusvulgaris L.) }\end{array}$ & $\begin{array}{c}\text { Caule (haste) } \\
\text { Vagem }\end{array}$ & $\begin{array}{l}\text { Fazenda Agua Limpa da } \\
\text { Universidade de Brasília. }\end{array}$ \\
\hline $\begin{array}{c}\text { Madeira de const. Civil } \\
\text { (Diversos) }\end{array}$ & $\begin{array}{c}\text { Serragem } \\
\text { Maravalhas }\end{array}$ & $\begin{array}{l}\text { Cooperativa Sonho de Liberdade, } \\
\text { instalada na Cidade Estrutural/DF. }\end{array}$ \\
\hline $\begin{array}{l}\text { Madeira de serraria } \\
\text { (Diversos) }\end{array}$ & $\begin{array}{l}\text { Serragem } \\
\text { Maravalhas }\end{array}$ & $\begin{array}{l}\text { Serraria Landy, instalada no Setor de } \\
\text { Indústrias e Abastecimento/DF. }\end{array}$ \\
\hline $\begin{array}{c}\text { Milho } \\
\text { (ZeamaysL.) }\end{array}$ & Sabugo & $\begin{array}{l}\text { Cooperativa Agrícola do Rio Preto, } \\
\text { instalada na região de Planaltina/DF. }\end{array}$ \\
\hline
\end{tabular}

Por se tratar de resíduos madeireiros não foi possível a identificação precisa das espécies que deram origem a serragem, tanto para os resíduos de construção civil como os de serraria, pois diversas espécies são serradas ou trabalhadas eventualmente, e todo o material residual do processo é armazenado de forma conjunta. Porém, através de levantamento realizado, tem-se que as principais espécies trabalhadas na serraria são ipê, cumaru, curupixá e jequitibá, madeiras de maior densidade. Já para os resíduos de madeiras de construção civil o levantamento de espécies trabalhadas foi mais complexo uma vez que são recebidas na cooperativa resíduos de obras de todo o Distrito Federal, sendo ripas, caibros, tábuas, madeira de escoramento, madeirite, etc. Contudo, foi observado em sua maioria eucalipto e pinus, madeiras de média a baixa densidade. A Figura 5 mostra fotos das biomassas in natura utilizadas neste trabalho. 

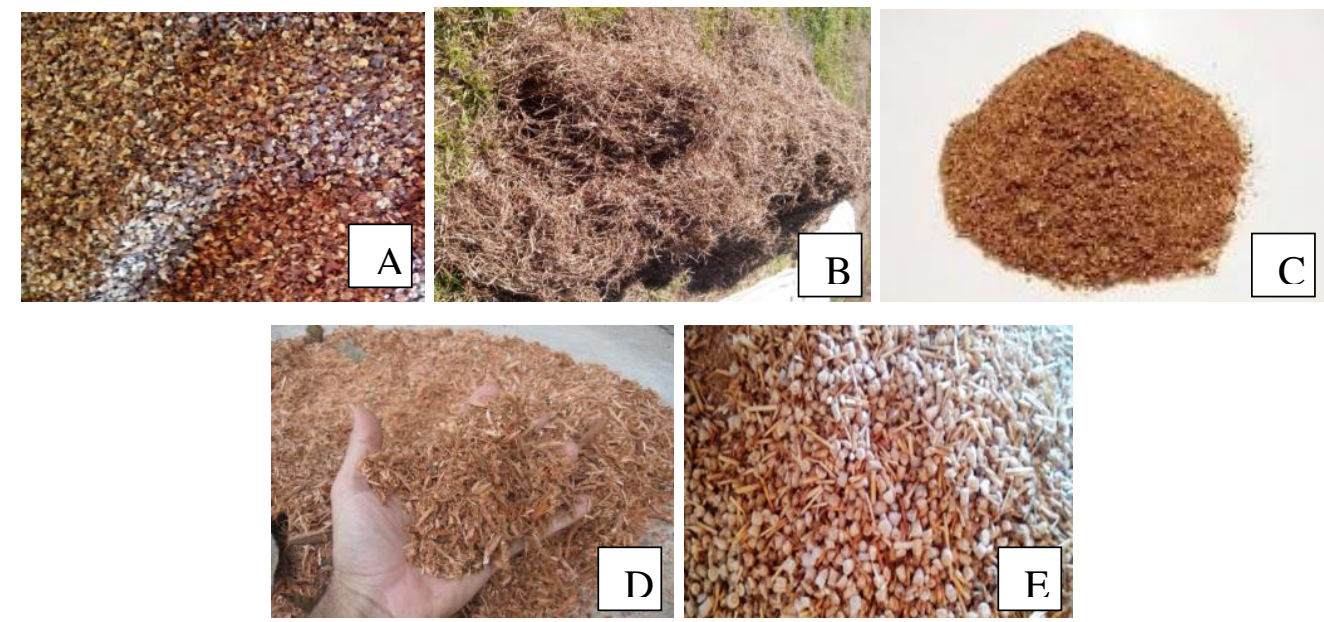

Figura 5. Biomassas utilizadas. A) palha de café; B) madeira de construção civil; C) sabugo de milho; D) madeira de serraria; E) palha de feijão. (Foto: Autora, 2016).

Os resíduos de biomassa foram caracterizados in natura; carbonizados e briquetados. O trabalho foi realizado no Laboratório de Tecnologia de Madeira do Departamento de Engenharia Florestal da UnB (EFL/UnB) em parceria com o Laboratório de Produtos Florestais do Serviço Florestal Brasileiro (LPF/SFB). É importante salientar que os resíduos não passaram por nenhum processo de redução no tamanho de suas partículas, após a coleta e antes de serem peneiradas.

\subsection{Caracterização das propriedades da biomassa in natura}

\subsubsection{Densidade do granel}

A densidade a granel dos diferentes resíduos foi determinada conforme a norma NBR 6922 (ABNT, 1983), a qual consiste na alocação dos resíduos em uma caixa com dimensões conhecidas para ser pesado, em seguida foi realizada a diferença da massa total (caixa + material) com a massa do recipiente (caixa vazia) para se obter a massa da amostra, assim, para a determinação da densidade a granel foi utilizada a relação entre massa de material e volume do recipiente. O procedimento descrito foi realizado para todos os resíduos utilizados no estudo em condições ambientes de temperatura e umidade relativa. 


\subsubsection{Classificação granulométrica}

A análise granulométrica foi baseada na norma NBR NM 248 (2003) “AgregadosDeterminação da composição granulométrica", com adaptações. A massa pesada de cada amostra foi de aproximadamente $100 \mathrm{~g}$ de material úmido (nas condições de coleta).

As peneiras da série TYLER utilizadas apresentavam diferentes diâmetros de abertura $(16,8,4,2,1$ e 0,5 milímetros) e encaixadas junto ao fundo de peneiras, com abertura de malha em ordem decrescente do topo para a base.

A amostra pesada foi cuidadosamente colocada sobre a peneira superior de forma que evitasse a formação de uma camada espessa de material sobre as demais. No intervalo entre as análises, as peneiras foram limpas utilizando pincel, minimizando assim possíveis interferências. As análises foram realizadas com o auxílio do Peneirador Eletromagnético da BERTEL.

A agitação do conjunto de peneiras foi mecânica, durando 20 minutos com vibração de $100 \%$ para cada amostra. Em seguida, verificou-se a quantidade de material retido e passante de cada peneira, conforme ilustra a Figura 6, e determinada a massa total destes materiais.

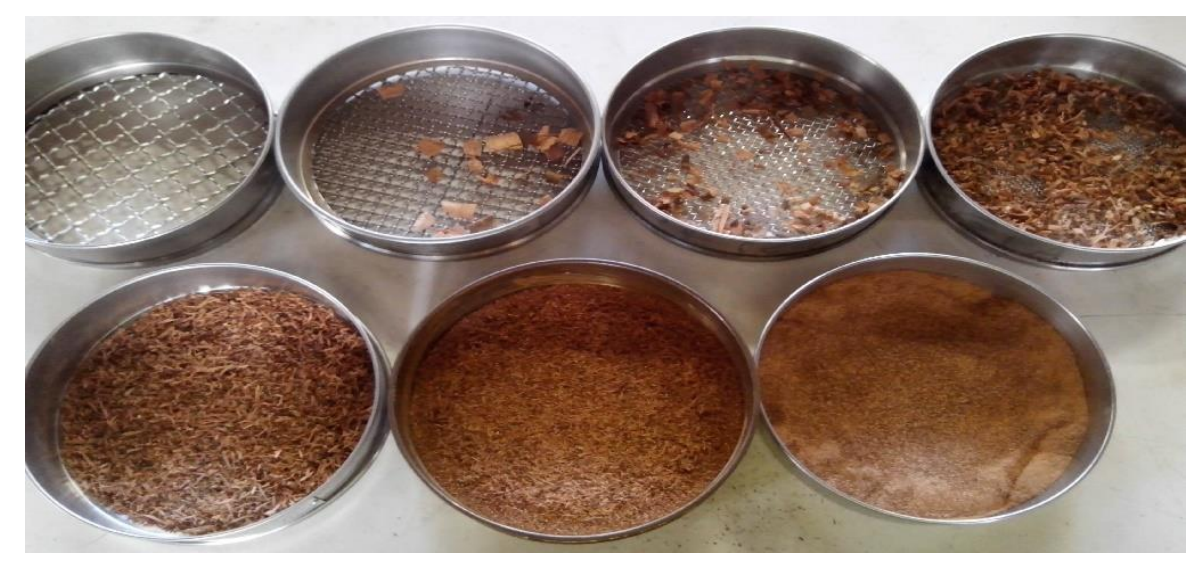

Figura 6. Peneiras utilizadas para classificação granulométrica (Foto: Autora, 2016).

Segundo a norma, o somatório de todas as massas não deve diferir mais de $0,3 \%$ da massa da amostra inicialmente introduzida no conjunto de peneiras. A distribuição granulométrica foi obtida com os dados de porcentagem de massa retida e o valor de abertura de cada peneira. 


\subsubsection{Teor de umidade}

O teor da umidade (TU) foi calculado segundo Vital (1997) e a norma ABNT NBR 7190 em função da relação entre a massa úmida $(\mathrm{Mu})$ e a massa seca $(\mathrm{Ms})$, conforme Equação 2. Neste ensaio foi utilizada uma balança com sensibilidade $10^{-2} \mathrm{~g}$

$$
T u=\frac{m u-m s}{m s} * 100(\text { Equação } 2)
$$

Onde:

$\mathrm{Tu}=$ teor de umidade $(\%)$;

$\mathrm{mu}=$ massa úmida $(\mathrm{g})$;

$\mathrm{ms}=$ massa seca a $0 \%$ de umidade $(\mathrm{g})$.

\subsubsection{Análise imediata}

A composição química imediata da biomassa, que corresponde aos teores de materiais voláteis, cinzas e carbono fixo, em base seca, foram determinados de acordo com a norma ABNT NBR 8112 (ABNT, 1986), com adaptações.

As adaptações consistiram na realização de ensaios em triplicata, na utilização de uma granulometria de 60 mesh para todos os ensaios, a substituição dos cadinhos de platina por cadinhos de cerâmica e na massa utilizada para a determinação dos teores de cinzas que foi aumentada para $2 \mathrm{~g}$, visando o aumento proporcional das cinzas medidas.

\section{- Teor de cinzas:}

Para a determinação do teor de cinzas, adotou-se os seguintes passos:(i) pesar 2,0 g do material com granulometria menor que 60 mesh e a $0 \%$ de umidade; (ii) colocar o material em cadinho de cerâmica, previamente seco e tarado; (iii) colocar o cadinho no interior da mufla, fechar a porta, deixando-o por 5 horas a $700 \pm 10^{\circ} \mathrm{C}$; (iv) retirar a amostra da mufla, esfriar no dessecador e pesar.

Para cada amostra foi realizada uma triplicata e o teor de cinzas foi calculado de acordo com a Equação 3.

$$
C z=\frac{m f-m c}{m 1} * 100(\text { Equação } 3)
$$


Em que,

$\mathrm{Cz}=$ Quantidade de cinzas $(\%)$

$\mathrm{m}_{\mathrm{f}}=$ Massa do cadinho + massa do resíduo $(\mathrm{g})$

$\mathrm{m}_{\mathrm{c}}=$ Massa do cadinho $(\mathrm{g})$

$\mathrm{m}_{\mathrm{a}}=$ Massa da amostra $(\mathrm{g})$

Em seguida foram calculados valores relativos entre as triplicatas, visto que eles não podem ultrapassar $10 \%$.

\section{- Teor de voláteis:}

Para a determinação do teor de materiais voláteis, adotou-se os seguintes passos: (i) pesar 1,0 g do material com granulometria menor que 60 mesh e a $0 \%$ de umidade; (ii) colocar o material em cadinho de cerâmica com tampa, previamente seco e tarado; (iii) aquecer previamente o forno mufla com uma rampa e um patamar a $900 \pm 10^{\circ} \mathrm{C}$ e colocar o cadinho com o material tampado sobre a porta da mufla aquecida durante 3 minutos; (iv) colocar o cadinho no interior da mufla e fechar a porta, deixando-o por 7 minutos; (v) retirar a amostra da mufla, esfriar no dessecador e pesar.

Para cada amostra foi realizada uma duplicata e o teor de voláteis foi calculado de acordo com a Equação 4.

$$
M v=\frac{m 1-m 2}{m 1} * 100(\text { Equação } 4)
$$

Em que:

$\mathrm{Mv}=$ Teor de materiais voláteis $(\%)$;

$\mathrm{m} 1=$ Massa inicial do cadinho $+\operatorname{amostra}(\mathrm{g})$;

$\mathrm{m} 2=$ Massa final do cadinho + amostra $(\mathrm{g})$.

\section{- Teor de carbono fixo:}

Enfim, para encontrar o teor de carbono fixo foi utilizada a Equação 5.

$$
C f=100-(C z+M v)(\text { Equação 5) }
$$


Em que,

$\mathrm{Cf}=$ Carbono fixo $(\%)$

$\mathrm{Cz}=\operatorname{Cinzas}(\%)$

Mv = Voláteis (\%)

\subsubsection{Composição química}

Os procedimentos utilizados para a determinação dos teores de extrativos, de lignina ácida, e cinzas livres de extrativos, seguiram os protocolos do Laboratório de Produtos Florestais - LPF do Serviço Florestal Brasileiro, uma vez que os ensaios foram realizados nas dependências do mesmo. Todos os ensaios foram realizados em triplicata.

\section{- Teor de extrativos}

A metodologia empregada nesta determinação segue a norma TAPPI 204 om-88 (Solvent extratives of wood and pulp), com adaptações.

Os balões de extração foram secos em estufa a $115^{\circ} \mathrm{C}$ por duas horas e colocados em dessecador para esfriar, em seguida suas massas foram medidas e anotadas. Preparouse em capela de exaustão, uma mistura de Etanol:Tolueno, na proporção em volume de (1:2) respectivamente, a qual foi utilizada para preencher os balões de extração com aproximadamente $210 \mathrm{~mL}$. Considerando 5 unidades experimentais com 3 repetições.

Cada amostra do material a ser analisado foi moído e classificado, utilizando-se a fração que passou pela peneira com malha de 40 mesh e ficou retida na peneira com malha de 60 mesh. De cada unidade experimental foram separadas três amostras com massa de aproximadamente $5 \mathrm{~g}$ e acondicionadas em casulos de celulose e tampados com algodão. Cada casulo contendo suas respectivas alíquotas foi inserido na coluna de extração do Soxhlet, conforme ilustra a Figura 7.

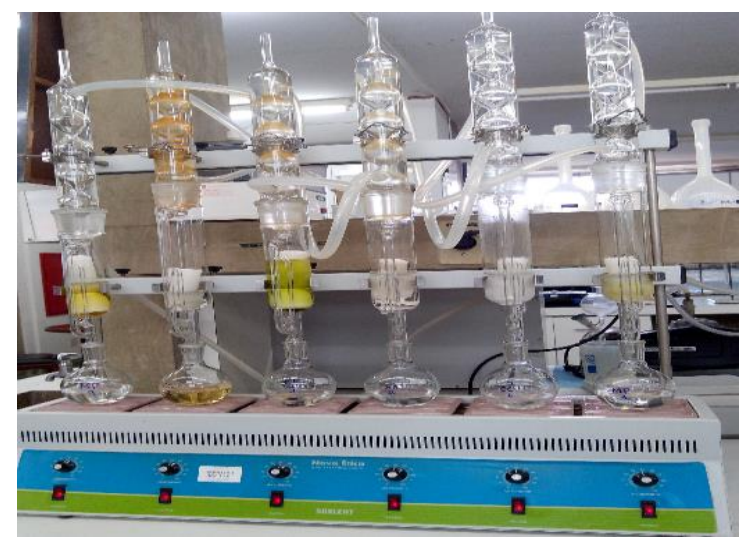

Figura 7. Baterias de extratores Soxhlet utilizadas para a determinação do teor de extrativos (Foto: Autora, 2016). 
Logo em seguida, os balões foram encaixados em extratores Soxhlet e assentados sobre as placas aquecedoras. Após o período de extração, foram retirados gradativamente das colunas de extração os solventes sem extrativos, permanecendo aproximadamente 2 $\mathrm{mL}$ de solvente com extratos em cada balão de extração. Os balões com os extratos foram secos por duas horas em estufa com circulação de ar a $115^{\circ} \mathrm{C}$.

O cálculo do teor de extrativos em etanol:tolueno foi realizado utilizando-se a Equação 6.

$$
T e=\frac{m 2-m 1}{m} * 100 \quad(\text { Equação } 6)
$$

Onde,

$\mathrm{Te}=$ teor de extrativos (etanol:tolueno) em percentual $(\%)$;

$\mathrm{m}=$ massa da amostra descontada a umidade;

$\mathrm{m} 1$ = massa do balão de extração;

$\mathrm{m} 2$ = massa do balão de extração + extratos após secagem a $115^{\circ} \mathrm{C}$ em estufa por 2 horas.

A determinação da umidade das amostras para obtenção da massa seca foi obtida de forma indireta, onde as análises de teor de umidade foram realizadas em paralelo a determinação do teor de extrativos, porém no mesmo dia e sob as mesmas condições. $\mathrm{O}$ cálculo do teor de umidade foi realizado utilizando-se a Equação 7.

$$
T u=\frac{m u-m s}{m u} * 100(\text { Equação } 7)
$$

Onde,

$\mathrm{Tu}=$ teor de umidade em percentual $(\%)$

mu= massa úmida da amostra

$\mathrm{ms}=$ massa seca da amostra

\section{- Teor de cinzas}

Para a determinação dos teores de cinzas das amostras, foi utilizada a Norma TAPPI T211 om-93 "Ash in wood, pulp, paper and paper board combustion at $525^{\circ} \mathrm{C}$ ". Este teor de cinzas foi utilizado apenas para a determinação dos teores de lignina insolúvel.

Os cadinhos foram previamente calcinados, os mesmos foram colocados em 
dessecador para esfriar e em seguida suas massas foram medidas. Na sequência foi medido aproximadamente $2,0 \mathrm{~g}$ de cada amostra absolutamente seca, dentro de cada cadinho cerâmico. Após tal procedimento os cadinhos já com as amostras foram colocados na mufla, a uma temperatura de $525^{\circ} \mathrm{C}$, até queima completa. $\mathrm{O}$ cálculo do teor de cinzas foi realizado conforme a Equação 8.

$$
C z_{525^{\circ} \mathrm{C}}=\frac{m 1-m 0}{m} * 100(\text { Equação } 8)
$$

Onde,

$\mathrm{CZ}_{525^{\circ} \mathrm{C}}=$ teor de cinzas em percentual $(\%)$;

$\mathrm{m}=$ massa da amostra a 0\% de umidade;

$\mathrm{m} 0$ = massa do cadinho;

$\mathrm{m} 1=$ massa do cadinho + amostra calcinada a $525^{\circ} \mathrm{C}$.

\section{- Teor de lignina}

Para realizar as operações de isolamento de lignina ácida (Lignina Klason), as amostras foram submetidas à limpeza, com etanol e posteriormente com água quente, além de limpeza inicial com etanol:tolueno, conforme norma TAPPI 204 om-88 (Solvent extratives of wood and pulp).

Para a determinação dos teores de lignina insolúvel e lignina solúvel, foram adotados os procedimentos laboratoriais LAP \#003 (Templeton \& Ehrman, 1995) e LAP \#004 (Templeton \& Ehrman, 1995) respectivamente, do National Renewable Energy Laboratory - NREL. A Figura 8 ilustra os procedimentos adotados.

Hiârólise ácicià

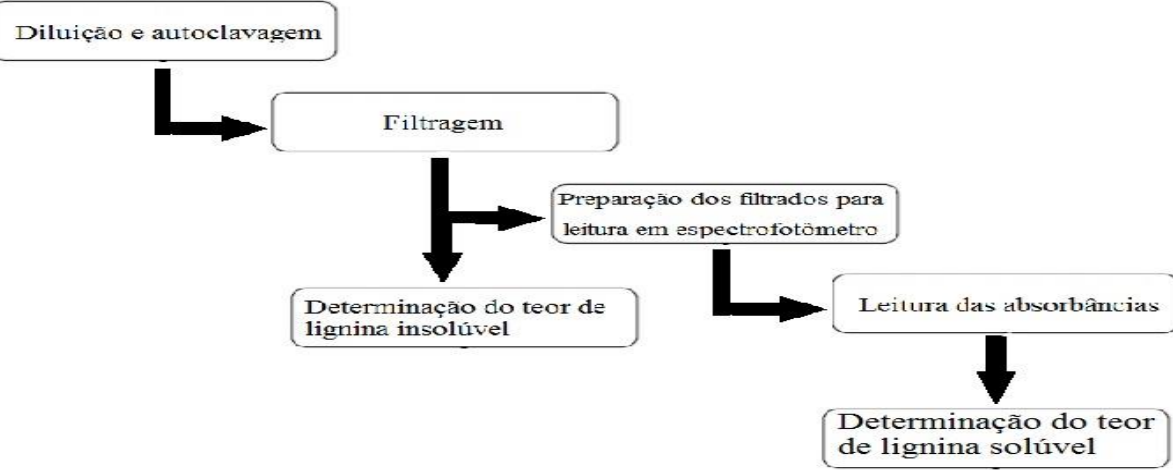

Figura 8. Fluxograma de determinação do teor de lignina ácida, insolúvel e solúvel. 
A metodologia empregada neste experimento segue os procedimentos da norma Laboratory Analytical Procedure \#003 (Templeton \& Ehrman, 1995).

Foram pesadas três amostras de cada unidade experimental com aproximadamente $300 \mathrm{mg}$, diretamente em tubos de ensaio previamente identificados. Nestes, foi adicionado $3 \mathrm{~mL}$ de $\mathrm{H}_{2} \mathrm{SO}_{4}$ a $72 \%(\mathrm{p} / \mathrm{p})$ e com um bastão de vidro misturou-se o ácido com a amostra durante um minuto, garantindo a completa embebição da amostra no ácido. Os tubos de ensaio foram colocados em banho-maria a $30^{\circ} \mathrm{C}$ durante 2 horas, onde se repetiu a misturado material, com bastão de vidro nos tubos de ensaio a cada 15 minutos.

Decorridas duas horas, o conteúdo de cada tubo de ensaio foi transferido para frascos de vidro devidamente identificados. Foi adicionado $84 \mathrm{~mL}$ de água deionizada em cada frasco, desta forma, a concentração do ácido para hidrólise baixou para 4 \% (p/p). Após tal transferência, cada frasco foi tampado com tampas de borracha e lacrado com anel de alumínio, onde tais frascos foram transferidos para o aparelho de autoclave e autoclavados a $121^{\circ} \mathrm{C}$ por uma hora. Após o ciclo de autoclavagem, os frascos foram resfriados à temperatura ambiente por 20 minutos.

Após o resfriamento o conteúdo de cada frasco de vidro, foi devidamente filtrado a vácuo em cadinho filtrante, onde a parcela líquida de cada um foi transferida para kitassatos distintos para posterior análise em espectrofotômetro. A parcela de lignina insolúvel foi lavada do frasco com água deionizada quente, visando transferir para cadinhos filtrantes, devidamente identificados, qualquer lignina sólida do frasco. Cada cadinho filtrante contendo a lignina ácida insolúvel foi seca em estufa a $105^{\circ} \mathrm{C}$, até a estabilização da massa. A Figura 9 ilustra a sequência de hidrólise ácida, autoclavagem e filtragem da lignina.
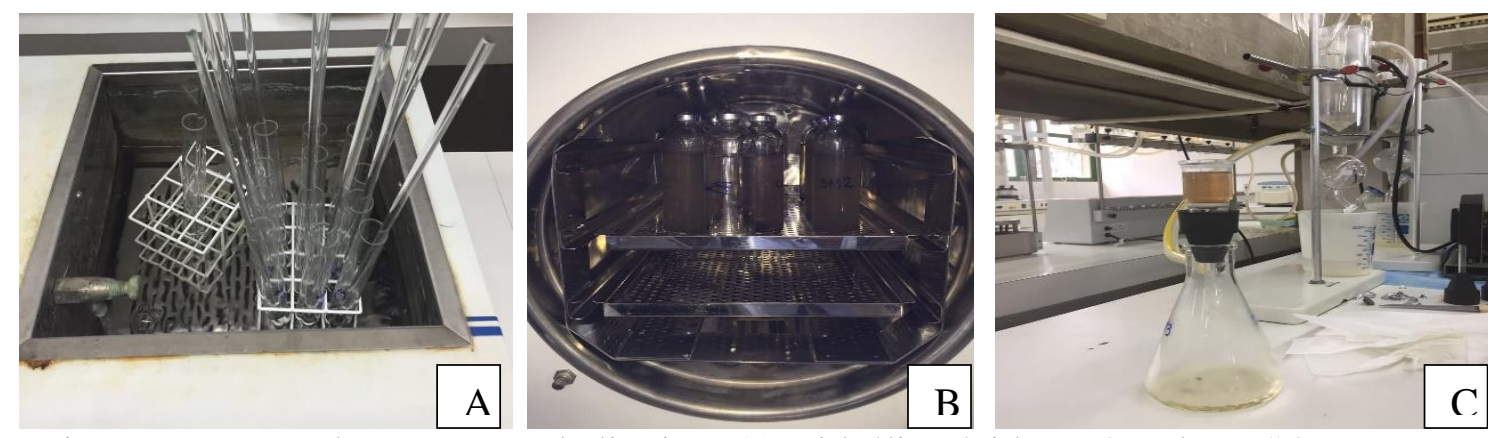

Figura 9. Etapas da separação da lignina. A) Hidrólise ácida a $72 \%$ de $\mathrm{H}_{2} \mathrm{SO}_{4}$. B) Frascos para autoclavagem com $\mathrm{H}_{2} \mathrm{SO}_{4}$ a $4 \%$. C) Filtragem da lignina após processo de autoclave (fotos da autora, 2016). 
Para o cálculo do teor de lignina ácida insolúvel utilizou-se a Equação 9.

$$
L i_{\text {ins }}=\frac{m 2-m 1}{m} * 100(\text { Equação } 9)
$$

Onde,

$\mathrm{Li}_{\text {ins }}=$ teor de lignina ácida insolúvel em percentual $(\%) ;$

$\mathrm{m}=$ massa da amostra descontada a umidade;

$\mathrm{m} 1$ = massa do cadinho filtrante;

$\mathrm{m} 2$ = massa do cadinho filtrante + lignina ácida insolúvel descontada as cinzas.

\section{Teor de lignina ácida solúvel}

A metodologia empregada neste experimento segue os procedimentos Laboratory Analytical Procedure \#004 (Templeton\&Ehrman, 1995).

Foi preparada uma solução de $\mathrm{H}_{2} \mathrm{SO}_{4}$ a $4 \%$ (p/p), para isto mediu-se $3 \mathrm{~mL}$ de $\mathrm{H}_{2} \mathrm{SO}_{4}$ a $72 \%$ (p/p) e diluiu-se a solução com a adição de $84 \mathrm{~mL}$ de água deionizada. De posse desta solução, preparou-se um branco a ser utilizado como referência no espectrofotômetro, medindo-se $1 \mathrm{~mL}$ do $\mathrm{H}_{2} \mathrm{SO}_{4}$ a $4 \%$ e diluindo o mesmo com água deionizada, até completar $10 \mathrm{~mL}$ em balão volumétrico separado para tal finalidade.

Do filtrado de cada kitassato, que foi separado na etapa da filtragem na determinação da lignina insolúvel, foi retirado uma alíquota de $1 \mathrm{~mL}$ e diluído com água deionizada até completar $10 \mathrm{~mL}$ em balão volumétrico. Ligou-se o espectrofotômetro e regulou-se o comprimento de onda do aparelho para $205 \mathrm{~nm}$, colocou-se a amostra do branco em cubeta de referência, o aparelho foi calibrado de forma que a leitura do branco no valor de absorbância fosse 0,000 . Cada amostra já devidamente diluída foi colocada em cubetas distintas e efetuou-se as leituras das absorbâncias.

A Equação 10, utilizada para a obtenção do teor de lignina solúvel é expressa por:

$$
L i_{(s o l)}=\frac{\frac{a}{110} * f * \frac{87}{1000}}{m} * 100(\text { Equação } 10)
$$


Onde,

$\mathrm{Li}_{(\mathrm{sol})}=$ teor de lignina solúvel em percentual $(\%)$;

$\mathrm{m}=$ massa da amostra absolutamente seca;

a = absorbância lida pelo espectrofotômetro;

$\mathrm{f}=$ fator de diluição;

\section{Teor de lignina total}

O teor de lignina total é um somatório entre a lignina insolúvel e a solúvel, e pode ser calculado pela Equação 11.

$$
L i_{\text {Total }}=L i_{\text {ins }}+L i_{\text {Sol }}(\text { Equação 11) }
$$

\section{- Teor de Holocelulose}

O teor de holocelulose $(\mathrm{TH})$, foi calculado por diferença, onde se subtraiu de $100 \%$, os teores percentuais da lignina total $\left(\mathrm{Li}_{\text {total }}\right)$, cinzas $\left(\mathrm{Cz}_{525^{\circ} \mathrm{C}}\right)$ e do teor de extrativos $(\mathrm{Te})$ conforme a Equação 12.

$$
T H=100 \%-L i_{\text {Total }}-C z_{525^{\circ} \mathrm{C}}-T e \text { (Equação 12) }
$$

\subsubsection{Análise elementar}

A análise elementar foi realizada na Central analítica do Instituto de Química da Universidade Federal de Brasília.

Por meio da análise elementar foi determinado o teor de carbono, hidrogênio, nitrogênio e, por diferença, o teor de oxigênio do material. Os resíduos foram peneirados e a alíquota utilizada foi a que passou pela peneira de 60 mesh. Após peneiramento, os resíduos foram secos em estufa convencional à temperatura de $(105 \pm 2){ }^{\circ} \mathrm{C}$.

Utilizando uma balança com precisão de $10^{-4} \mathrm{mg}$, foi pesado aproximadamente, 2 mg de resíduo em um porta-amostra de estanho. Em seguida, o conjunto (resíduo + porta amostra) foi depositado no carrossel do equipamento da marca Perkin Elmer® modelo EA 2400 Series II. O computador acoplado ao equipamento (Figura 11) realizou o cálculo dessa integração e forneceu os valores dos elementos em porcentagem. 


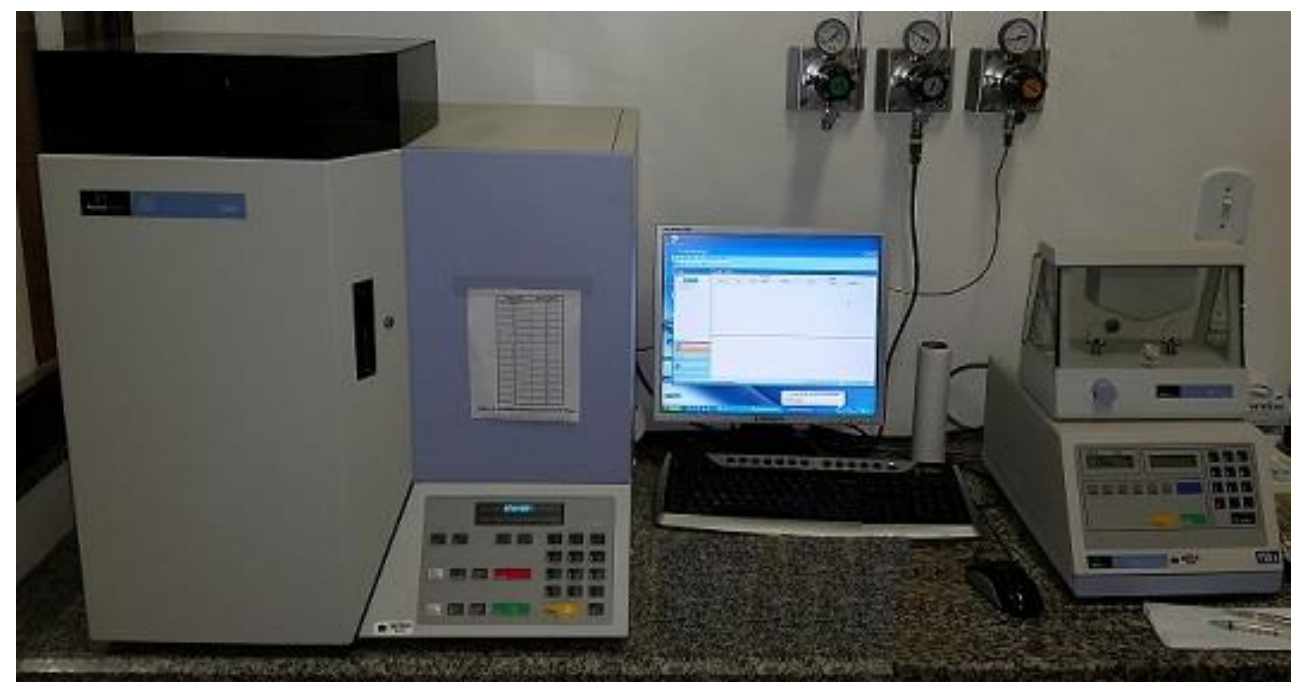

Figura 11. Analisador elementar.

\subsubsection{Poder calorífico}

Para o poder calorífico as amostras foram moídas e peneiradas, utilizando-se a fração que passou pela peneira com malha de 60 mesh.

\section{- Poder calorífico superior (PCS)}

A determinação do poder calorífico superior das amostras foi obtido experimentalmente através da bomba calorimétrica marca PARR 6400 Calorimeter (Figura 12), por meio da metodologia estabelecida na norma ABNT NBR 8633/1984. Os ensaios foram realizados em triplicata, considerando diferença igual ou inferior a $29 \mathrm{cal} / \mathrm{g}$.

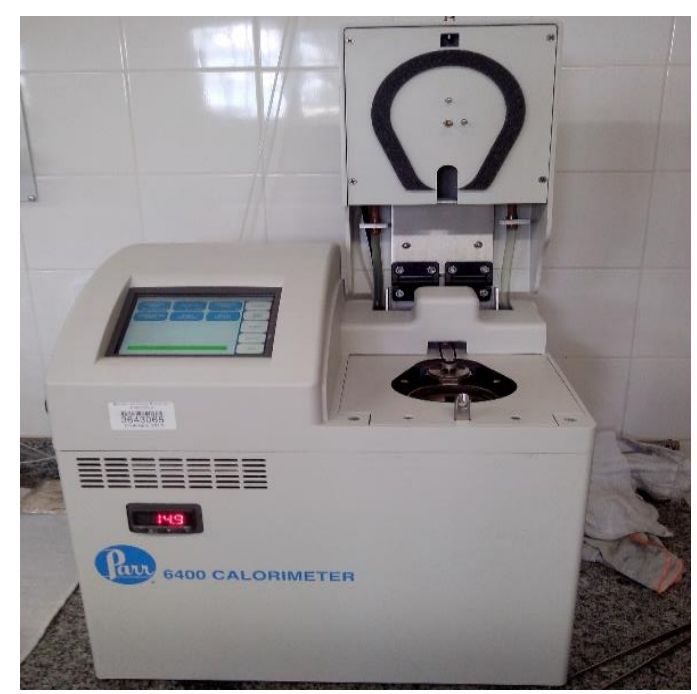

Figura 12- Bomba calorimétrica. (Foto da Autora, 2016). 


\section{- Poder Calorífico Útil (PCU)}

O poder calorífico útil (na umidade atual) foi determinado pela equação 13 descrita conforme Brito (1993):

$$
P C U=P C I(1-U)-600 U(\text { Equação 13) }
$$

onde:

$\mathrm{U}=$ umidade em base úmida $(\%)$.

$\mathrm{PCI}=$ poder calorífico inferior a $0 \%$ de umidade.

Sendo:

$$
P C I=P C S-600 *\left(\frac{9 * H}{100}\right)
$$

Onde:

PCS $=$ poder calorífico superior.

$\mathrm{H}=$ teor de hidrogênio

\subsubsection{Densidade energética}

O valor de densidade energética foi calculado pelo produto entre o poder calorífico superior e a densidade básica conforme ilustrado pela Equação 14.

$$
D e=P C u \times D g_{u} \% \text { (Equação 14) }
$$

Onde,

De $=$ Densidade energética $\left(\mathrm{kcal} / \mathrm{m}^{3}\right)$

$\mathrm{PCu}=$ Poder calorífico útil $(\mathrm{kcal} / \mathrm{kg})$

$\operatorname{Dg}_{\mathrm{u} \%}=$ Densidade do granel úmido $\left(\mathrm{kg} / \mathrm{m}^{3}\right)$

\subsection{Carbonização}

\subsubsection{Determinação do perfil térmico}

As temperaturas de cada carbonização foram registradas em intervalos de 1 minuto durante a carbonização e o resfriamento do forno. 
A partir das temperaturas obtidas pelos dois pontos de medição instalados, um em contato com a resistência e outro dentro da câmara de carbonização, realizou-se o mapeamento térmico do forno durante a carbonização.

O perfil de carbonização (Figura 13) foi elaborado a partir das temperaturas registradas durante a carbonização e o resfriamento por meio do software PIROLISE 10L, que representa, em cores, a evolução da temperatura ao longo do tempo. O princípio do software consiste em plotar os valores das temperaturas (x) no tempo (min).

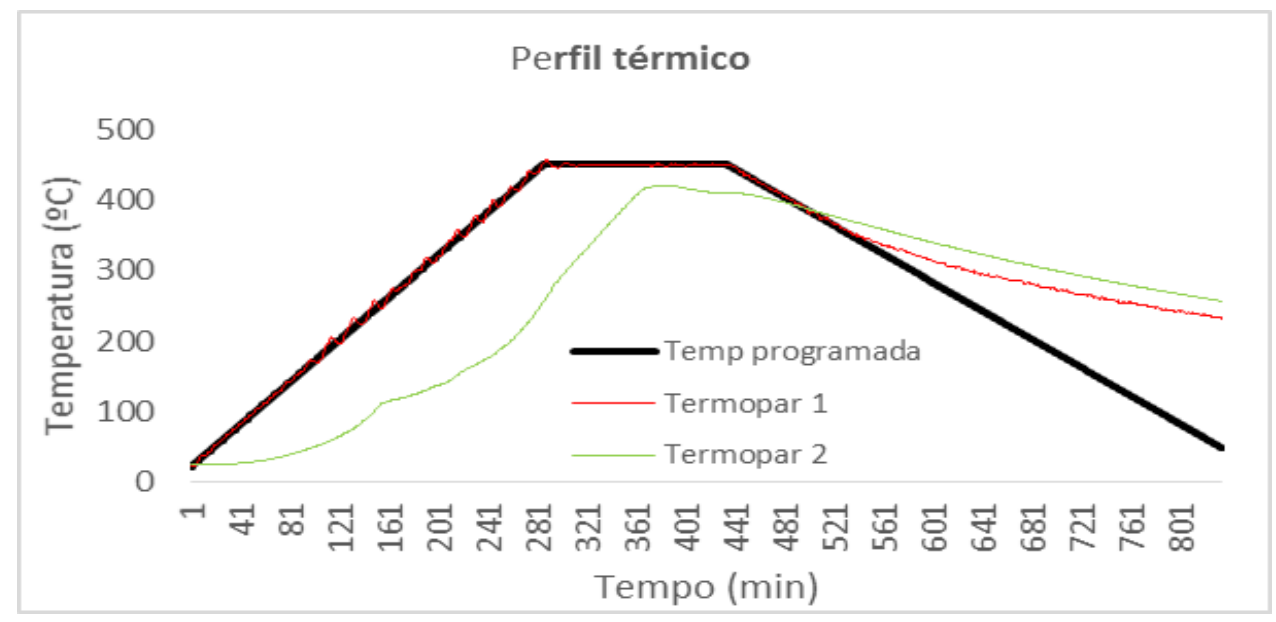

Figura 13. Perfil térmico de carbonização.

A linha preta presente no gráfico da Figura 13 é a temperatura programada no software que realiza o controle do reator. A linha vermelha indica a temperatura do termopar 1 que fica em contato com a resistência, para controle da temperatura de aquecimento. A linha verde indica a temperatura do termopar 2 que ficou inserido dentro da câmara de carbonização, em contato com material que foi sendo carbonizado. A figura 14 indica a posição de cada termopar.

\subsubsection{Definição do protocolo de carbonização}

As carbonizações foram realizadas em um reator, tipo retorta elétrica (Figura 14). Para o processo, foram utilizados os parâmetros: temperatura final $\left(450^{\circ} \mathrm{C}\right)$, tempo de patamar (150 minutos) e taxa de aquecimento $\left(1,5^{\circ} \mathrm{C} / \mathrm{min}\right)$ (Protásio et al., 2011). Para cada resíduo do estudo foram realizadas três carbonizações (repetições), sendo cada amostra constituída por aproximadamente $1,5 \mathrm{~kg}$ de material úmido (nas condições de coleta). 


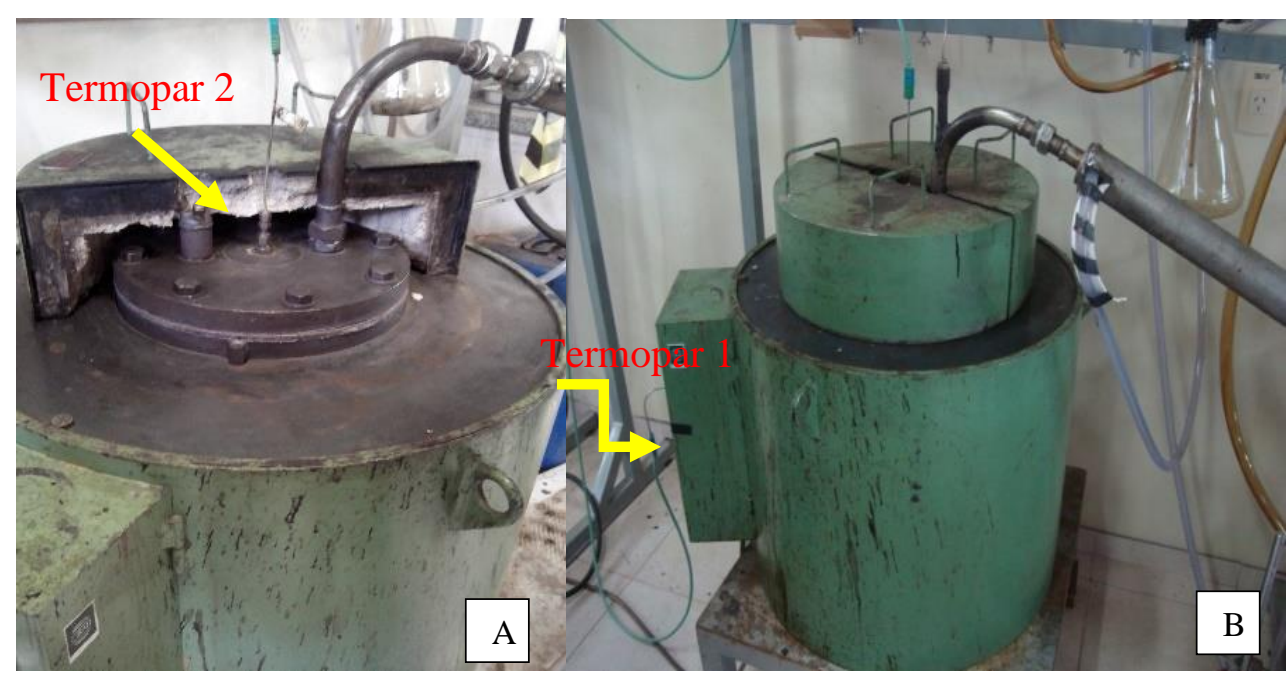

Figura 14. Reator de carbonização com indicação da posição dos termopares(Foto da Autora, 2016).

\subsubsection{Caracterização das propriedades do carvão}

\section{- Rendimento gravimétrico do carvão}

Foram determinados os rendimentos em carvão em relação ao resíduo seco, pela Equação 15.

$$
R G C=\frac{m c}{m s} * 100(\text { Equação } 15)
$$

Onde,

$\mathrm{RGC}=$ rendimento em carvão $(\%)$

$\mathrm{m}_{\mathrm{c}}=$ massa de carvão seco a $0 \%$ de umidade

$\mathrm{m}_{\mathrm{s}}=$ massa da biomassa seca a $0 \%$ de umidade

\section{- Análise imediata do carvão}

A composição química imediata do carvão vegetal, que corresponde aos teores de materiais voláteis, cinzas e carbono fixo, em base seca, foi determinada de acordo com a norma ABNT NBR 8112 (ABNT, 1986), com adaptações, conforme descrito no item 3.1.4.

\section{- Densidade do granel}

A densidade do granel dos resíduos carbonizados foi determinada conforme a 
norma NBR 6922 (ABNT, 1983), a qual consiste na relação entre a massa do material contido em uma caixa de volume conhecido e este volume, conforme descrito no item 3.1.1.

\section{- Poder calorífico}

A determinação do poder calorífico superior das amostras foi obtido, experimentalmente, através da bomba calorimétrica marca PARR 6400 Calorimeter, por meio da metodologia estabelecida na norma ABNT NBR 8633/1984, conforme descrito no item 3.1.7.

\section{- Densidade energética}

O valor de densidade energética foi calculado pelo produto entre o poder calorífico superior e a densidade do granel seco conforme ilustrado pela Equação 16.

$$
\mathrm{De}=\mathrm{PCu} \times \mathrm{Dg} \% \text { (Equação 16) }
$$

Em que,

$\mathrm{De}=$ Densidade energética $\left(\mathrm{kcal} / \mathrm{m}^{3}\right)$

$\mathrm{PCu}=$ Poder calorífico útil $(\mathrm{kcal} / \mathrm{kg})$

$\mathrm{Dg}_{\%}=$ Densidade do granel $\left(\mathrm{kg} / \mathrm{m}^{3}\right)$

\subsection{Briquetagem}

\subsubsection{Definição do protocolo de briquetagem}

Para o processo de produção dos briquetes os resíduos carbonizados (palha de café, palha de feijão, madeira de construção civil, madeira de serraria e sabugo de milho) foram moídos e classificados utilizando-se a fração que passou pela peneira de 40 mesh e homogeneizados entre si em uma proporção de 1:1, resultando em uma amostra composta.

Foram utilizados dois tipos de aglutinantes, resíduos (quirela) de milho e sorgo, conforme ilustra a Figura 15, resultantes do processamento e beneficiamento dos mesmos. Tais resíduos foram moídos e classificados utilizando-se a fração que passou pela peneira de 60 mesh. Os resíduos mencionados foram coletados na Cooperativa Agrícola do Rio Preto, localizada na região de Rio Preto/ DF. 


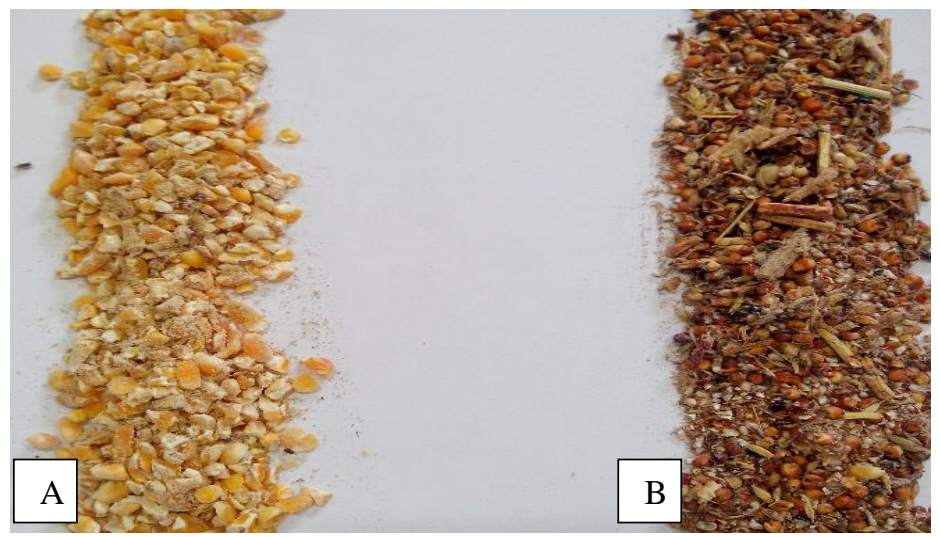

Figura 15. Resíduos utilizados como aglutinante: quirelas de milho (A) e de sorgo (B).

No preparo do aglutinante as quirelas moídas e classificadas foram misturadas na proporção de $50 \mathrm{~g}$ de quirela em $125 \mathrm{ml}$ de água destilada e gelatinizada à temperatura máxima de $80^{\circ} \mathrm{C}$ por aproximadamente 2 minutos, tempo suficiente para formar $\mathrm{o}$ aglutinante na forma de gelatina.

Para a confecção dos briquetes o carvão homogeneizado foi misturado com o aglutinante gelatinizado e posteriormente submetido a um processo de compactação utilizando prensa hidráulica a frio, modelo MARCON MPH-15 (Figura 16), com capacidade máxima de $15 \mathrm{t}$ e um molde de aço inox com $2,5 \mathrm{~cm}$ de diâmetro e $9,5 \mathrm{~cm}$ de altura, por um período de cinco minutos de compactação.
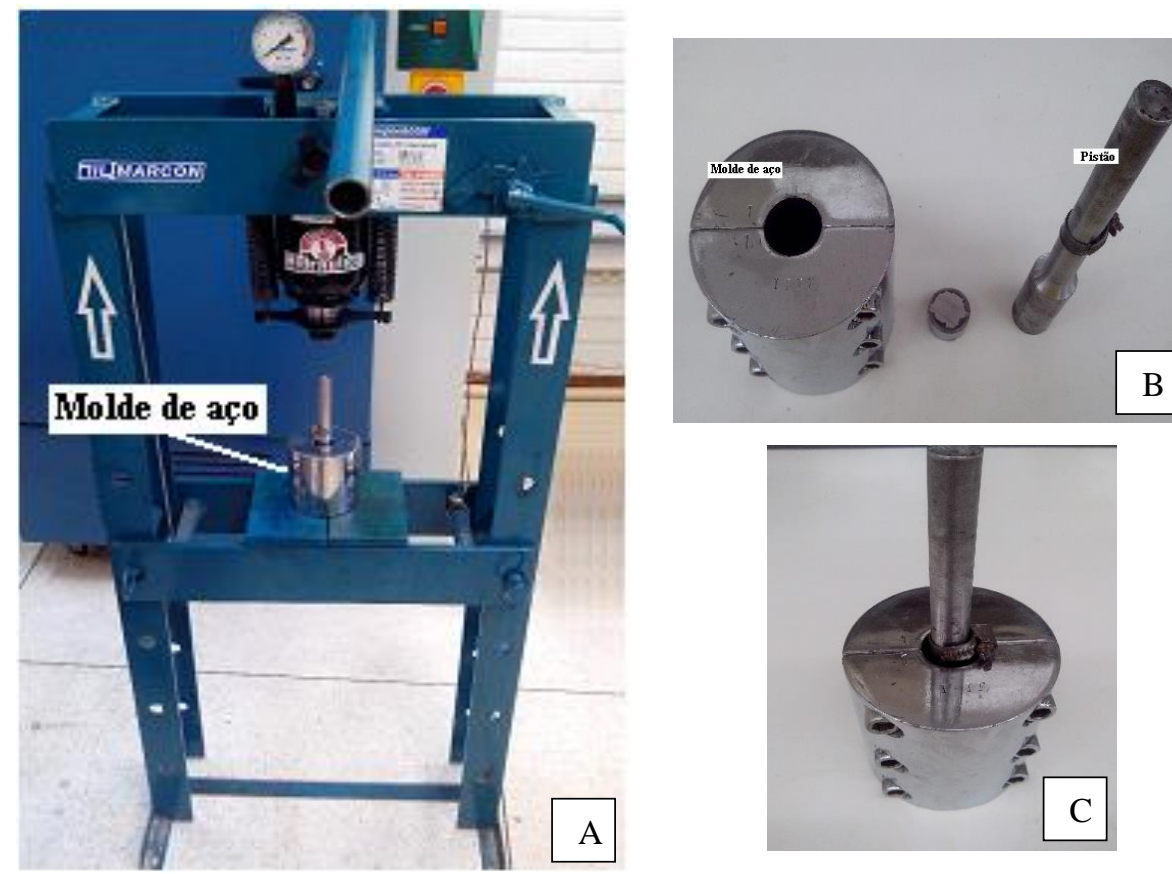

Figura 16. Sistema de compactação: A) Prensa hidráulica; B) Molde de aço inox com pistão; C) Detalhe do molde e pistão. (Foto da Autora, 2016). 
O experimento resultou em um delineamento inteiramente casualizado em esquema fatorial com três fatores (tipo de aglutinante, pressão e proporção de aglutinante) e nove repetições, conforme a tabela $\mathrm{x}$.

Tabela x. Delineamento experimental.

\begin{tabular}{|c|c|c|c|}
\hline Tratamentos & Aglutinante & Pressão & Mistura* \\
\hline 1 & \multirow{4}{*}{ Milho } & \multirow{2}{*}{50} & $60 / 40$ \\
\hline 2 & & & $70 / 30$ \\
\hline 3 & & \multirow{2}{*}{100} & $60 / 40$ \\
\hline 4 & & & $70 / 30$ \\
\hline 5 & \multirow{4}{*}{ Sorgo } & \multirow{2}{*}{50} & $60 / 40$ \\
\hline 6 & & & $70 / 30$ \\
\hline 7 & & \multirow{2}{*}{100} & $60 / 40$ \\
\hline 8 & & & $70 / 30$ \\
\hline
\end{tabular}

\subsubsection{Avaliação das propriedades dos briquetes}

\section{- Densidade aparente}

A densidade aparente dos briquetes foi determinada pelo método estequiométrico, que consiste em obter o volume a partir de medições, utilizando-se um paquímetro e a massa em uma balança analítica com precisão $10^{-3} \mathrm{~g}$. A densidade aparente a $0 \%$ de umidade foi determinada de acordo com a Equação 17.

$$
D a=\frac{m}{v}(\text { Equação } 17)
$$

Em que:

$D a=$ densidade aparente $\left(\mathrm{g} / \mathrm{cm}^{3}\right)$;

$m=$ massa do briquete $(\mathrm{g})$;

$v=$ volume do briquete $\left(\mathrm{cm}^{3}\right)$.

\section{- Determinação da resistência mecânica}

Para o ensaio da determinação da resistência mecânica dos briquetes, utilizou-se uma máquina universal de ensaios da marca EMIC do Laboratório de Tecnologia da Madeira, da Universidade de Brasília, com o aparato para compressão paralela ou 
perpendicular de corpos-de-prova de madeira.

Realizou-se o ensaio de compressão no sentido longitudinal do briquete (ou no sentido de compactação da biomassa) que pode ser visualizado na Figura 17.

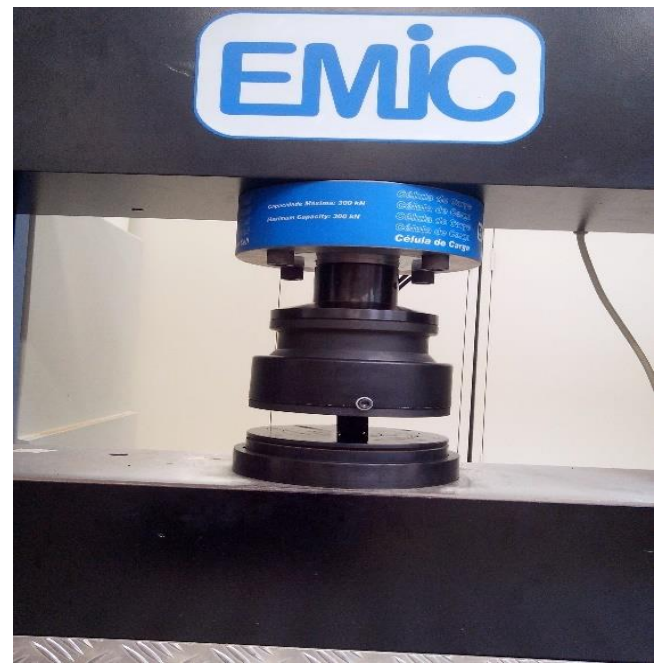

Figura17.Ensaio de resistência à compressão dos briquetes. (Foto da Autora, 2016).

Dada a não existência de norma específica para o ensaio mecânico com briquetes, adotou-se a norma da Comissão Panamericana de Normas Técnicas COPANT 30:1-008 (COPANT, 1971a) para a compressão no sentido paralelo da madeira, representando o sentido longitudinal do briquete.

\section{- Poder calorífico}

A determinação do poder calorífico superior das amostras foi obtido experimentalmente através da bomba calorimétrica marca PARR 6400 Calorimeter, por meio da metodologia estabelecida na norma ABNT NBR 8633/1984, conforme descrito no item 3.1.7.

\section{- Densidade energética}

O valor de densidade energética foi calculado pelo produto entre o poder calorífico superior e a densidade aparente conforme ilustrado pela Equação 18.

$$
\text { De }=\text { PCS x Da (Equação 18) }
$$

Em que, 
De $=$ Densidade energética $\left(\mathrm{kcal} / \mathrm{m}^{3}\right)$

PCS $=$ Poder calorífico Superior $(\mathrm{kcal} / \mathrm{kg})$

$\mathrm{Da}=$ Densidade aparente a $0 \%$ de umidade $\left(\mathrm{kg} / \mathrm{m}^{3}\right)$

\section{- Análise imediata do briquete}

A composição química imediata dos briquetes, que corresponde aos teores de materiais voláteis, cinzas e carbono fixo, em base seca, foram determinadas de acordo com a norma ABNT NBR 8112 (ABNT, 1986), com adaptações, conforme descrito no item 3.1.4.

\subsection{Análise de dados}

A Análise Estatística foi efetuada utilizando-se da Estatística Descritiva, Análise de Variância e teste de média.

As variáveis referentes à caracterização da biomassa in natura e do carvão foram analisadas estatisticamente através da Análise de Variância (ANOVA) e para a comparação múltipla foi utilizado o teste tukey, a $5 \%$ de significância. Adotou-se o delineamento inteiramente casualizado e três repetições.

$\mathrm{Na}$ avaliação dos briquetes, adotou-se o delineamento inteiramente casualizado disposto em esquema fatorial com três fatores (aglutinante, pressão e proporção de mistura entre o carvão e o aglutinante) e nove repetições. Para a comparação múltipla foi utilizado o teste tukey, a 5\% de significância.

As análises foram realizadas com o auxílio dos softwares Assistat 7.7 e Genes. 


\section{RESULTADOS E DISCUSSÕES}

Os resultados foram divididos em três partes sendo a primeira resultante das análises da biomassa in natura; a segunda referente a biomassa carbonizada e a última referente a biomassa carbonizada e compactada.

\subsection{Caracterização das propriedades dos resíduos in natura}

\subsubsection{Granulometria, teor de umidade e densidade do granel}

Na Figura 18 estão os resultados da distribuição granulométrica dos resíduos ilustrando a relação entre a abertura da malha das peneiras $(\mathrm{mm})$ e a porcentagem de retenção (\%) para cada resíduo.

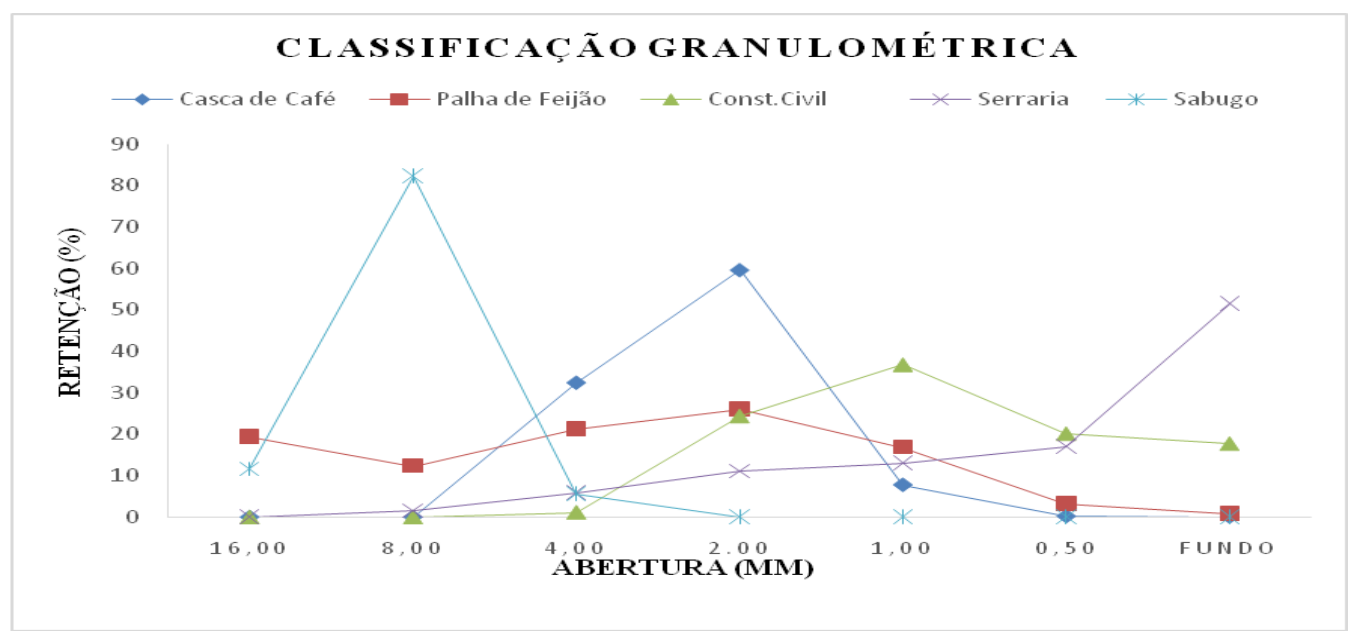

Figura 18. Classificação granulométrica dos resíduos analisados.

A palha de café apresentou maior retenção na malha de 2,00 mm, com 59,52\%, isso ocorreu devido ao fato do resíduo apresentar maior uniformidade em sua constituição. Enquanto que a palha de feijão apresentou retenção dispersa ao longo de todas as malhas, o que era esperado devido à heterogeneidade em sua constituição, sendo constituída por folhas, haste e vagem.

Os resíduos madeireiros de construção civil e serraria foram os que apresentaram menor granulometria, com destaque para os resíduos de serraria que apresentaram retenção de $51,49 \%$ abaixo de $0,50 \mathrm{~mm}$. No caso da construção civil a cooperativa apenas corta as madeiras em serra circular para confecção de, por exemplo, estacas de sinalização. Neste 
caso o corte da madeira produz uma serragem mais grossa. Já os resíduos de madeira de serraria apresentaram em sua composição, além de uma serragem grossa, pó do processo de trabalhabilidade da madeira com lixa, justificando a baixa granulometria.

Ainda na classificação granulométrica, pode-se observar que o sabugo apresentou partículas de maiores dimensões em comparação aos demais resíduos, com retenção de $82,29 \%$ na malha de $8,00 \mathrm{~mm}$.

$\mathrm{Na}$ Tabela 5, encontram-se os valores médios para teor de umidade (TUBS), densidade do granel úmido $\left(\mathrm{Dg}_{\mathrm{u}}\right)$.

Tabela 5. Teor de umidade e densidade a granel dos resíduos estudados.

\begin{tabular}{ccccccc}
\hline CARACTERÍSTICAS & UNIDADE & $\mathrm{CA}$ & $\mathrm{FE}$ & $\mathrm{CC}$ & $\mathrm{MM}$ & $\mathrm{SB}$ \\
\hline \multirow{2}{*}{$\mathrm{TU}_{\mathrm{BS}}$} & $\%$ & 12,93 & 8,63 & 8,85 & 12,04 & 8,53 \\
& \multirow{2}{*}{$\mathrm{DG}_{\mathrm{u}}$} & $(6,29)$ & $(3,59)$ & $(7,44)$ & $(0,36)$ & $(8,13)$ \\
\hline \multirow{2}{*}{$\mathrm{kg} / \mathrm{m}^{3}$} & 389,26 & 77,28 & 174,14 & 197,28 & 146,91 \\
& & $(1,73)$ & $(2,27)$ & $(1,15)$ & $(3,21)$ & $(2,90)$
\end{tabular}

Observação: Valores entre parênteses correspondem aos coeficientes de variação. CA: palha de café. FE: palha de feijão. CC: madeira de construção civil. MM: madeira de madeireira. SB: sabugo de milho.

A umidade do material é um índice primordial, quando se avaliam biomassas como fonte de bioenergia, pois, quanto maior a quantidade de água presente no combustível, menor será o seu valor calórico. Segundo Schutz et al. (2010) quanto menor for o teor de umidade de um combustível, maior será a quantidade de calor líquido liberado na sua combustão, pois parte da sua energia é empregada para aquecer e vaporizar a água do material. Observou-se que, em média, os resíduos in natura apresentaram 10,20\% de umidade na base seca. Para Farinhaque (1981), o teor de umidade ideal para a lenha queimar é até 25\%. Logo, os resíduos agroflorestais analisados apresentam valores considerados viáveis para processos envolvendo a queima do material.

Para a densidade do granel, o resíduo que apresentou maior valor foi a palha de café e o que apresentou o menor valor foi a palha de feijão, com 389,26 e 77,28 Kg/m³ , respectivamente, independente do teor de umidade. O elevado valor para a densidade a granel da palha de café pode ser explicado por características específicas do material como massa, forma, homogeneidade e granulometria o que favorece uma melhor acomodação implicando em maior quantidade de material por unidade volumétrica, ao contrário das características da palha de feijão que, devido a sua granulometria promovem um aumento nos espaços vazios e menor quantidade de material. 
Protásio et al. (2011) e Vale et al. (2007) encontraram valores inferiores ao encontrado neste estudo para a densidade do granel seco da casca de café, ambos da espécie Coffea arabica L., sendo 237 e $144 \mathrm{~kg} / \mathrm{m}^{3}$, respectivamente.

Albuquerque (2006) relacionou a densidade a granel de vários materiais com seu custo de transporte, afirmando que biomassas leves são pagas por metro cúbico, enquanto as pesadas são pagas por toneladas. Dessa forma, as de menor custo de transporte são as mais densas, como a casca do café. Protásio et al. (2011) reafirmam que é desejável que resíduos lignocelulósicos apresentem maiores valores de densidade a granel, pois fatores como os custos com o transporte e a densidade energética são essenciais na viabilidade econômica da energias renováveis.

A densidade a granel dos resíduos de madeira, tanto de construção civil como de serraria, foram semelhantes aos valores encontrados por Chrisostomo (2011) para serragem de pinus e eucalipto, 178,54 e $192,12 \mathrm{Kg} / \mathrm{m}^{3}$, respectivamente. Segundo Pinheiro et al. (2005) no estudo de densidade energética de resíduos vegetais, quanto à densidade a granel de serragem, podem ser encontrados valores na faixa de 150 (madeiras leves) a $250 \mathrm{~kg} / \mathrm{m}^{3}$ (madeiras pesadas).

\subsubsection{Análise imediata}

Na Tabela 6 estão apresentados os valores médios de teor de materiais voláteis (MV), teor de cinzas (CZ) e teor de carbono fixo (CF) para cada resíduo.

Tabela 6 - Valores médios de teor de materiais voláteis, teor de cinzas e teor de carbono fixo.

\begin{tabular}{ccccccc}
\hline CARACTERÍSTICAS & UNIDADE & CA & FE & CC & MM & SB \\
\hline \multirow{2}{*}{ MV } & $\%$ & 71,67 & 82,31 & 80,06 & 81,52 & 78,82 \\
& & $(0,57)$ & $(0,16)$ & $(0,76)$ & $(0,38)$ & $(0,56)$ \\
\hline \multirow{2}{*}{$\mathrm{CZ}$} & $\%$ & 7,69 & 8,70 & 2,45 & 0,69 & 3,81 \\
& \multirow{2}{*}{$\mathrm{O}$} & $(1,48)$ & $(2,43)$ & $(19,32)$ & $(3,85)$ & $(21,05)$ \\
\hline \multirow{2}{*}{$\mathrm{CF}$} & \multirow{2}{*}{$\%$} & 20,63 & 8,99 & 17,51 & 17,79 & 17,37 \\
& & $(1,44)$ & $(3,55)$ & $(1,66)$ & $(1,67)$ & $(2,10)$ \\
\hline
\end{tabular}

Observação: Valores entre parênteses correspondem aos coeficientes de variação. CA: palha de café. FE: palha de feijão. CC: madeira de construção civil. MM: madeira de madeireira. SB: sabugo de milho. 
Na Tabela 7 estão os valores de "F" para o teor de materiais voláteis (MV), teor de cinzas $(\mathrm{CZ})$ e teor de carbono fixo $(\mathrm{CF})$.

Tabela 7. Valores de "F" para teor de materiais voláteis, teor de cinzas e teor de carbono fixo.

\begin{tabular}{lllll}
\hline \multirow{2}{*}{ FV } & \multirow{2}{*}{ GL } & \multicolumn{3}{c}{ Valores de “F” } \\
\cline { 3 - 5 } & & MV & CZ & CF \\
\hline Tratamentos & 4 & $335.5037 * *$ & $189.7198 * *$ & $582.6670 * *$ \\
\hline Resíduo & 10 & & \\
\hline Total & 14 & & \\
\hline ** significativo ao nível de 1\% de probabilidade $(\mathrm{p}<.01)$ & & \\
$*$ * significativo ao nível de 5\% de probabilidade $(.01=<\mathrm{p}<.05)$ & \\
ns não significativo $(\mathrm{p}>=.05)$ &
\end{tabular}

É possível observa-se na Tabela 7 que houve diferença significativa pelo Teste $\mathrm{F}$ nos valores das características analisadas, ou seja, pelo menos uma das médias das características analisadas para cada resíduo difere entre si estatisticamente, sendo necessário realizar o teste de média. O resultado do teste de Tukey é apresentado na Tabela 8.

Tabela 8. Teste de Tukey para as médias de teor de material volátil (MV), teor de cinzas $(\mathrm{CZ})$ e carbono fixo $(\mathrm{CF})$.

\begin{tabular}{ccccccc}
\hline CARACTERÍSTICAS & UNIDADE & CA & FE & CC & MM & SB \\
\hline MV & $\%$ & $71,67 \mathbf{d}$ & $82,31 \mathbf{a}$ & $80,06 \mathbf{b}$ & $81,52 \mathbf{a}$ & $78,82 \mathbf{c}$ \\
\hline $\mathrm{CZ}$ & $\%$ & $7,69 \mathbf{a}$ & $8,70 \mathbf{a}$ & $2,45 \mathbf{c}$ & $0,69 \mathbf{d}$ & $3,81 \mathbf{b}$ \\
\hline $\mathrm{CF}$ & $\%$ & $20,63 \mathbf{a}$ & $8,99 \mathbf{c}$ & $17,51 \mathbf{b}$ & $17,79 \mathbf{b}$ & $17,37 \mathbf{b}$
\end{tabular}

Observação: Médias seguidas de mesma letra na linha não diferem entre si ao nível de 5\% de probabilidade. CA: palha de café. FE: palha de feijão. CC: madeira de construção civil. MM: madeira de madeireira. SB: sabugo de milho.

Maiores valores médios relacionados à presença de materiais voláteis foram observados no resíduo de palha de feijão e madeira de madeireira 82,31 e 81,52\% respectivamente, os quais não apresentaram diferença estatística entre si. A palha de café apresentou o menor valor médio para essa variável com 71,67\%. Essa característica indica que quando os mesmos forem submetidos em processos termoquímicos irão ser consumidos rapidamente, pois os voláteis são as substâncias que se desprendem do 
material combustível na forma de gases durante a queima da amostra. Eles estão diretamente ligados ao tempo de residência do material dentro de um equipamento de queima para geração de energia e influenciam diretamente a estabilidade da chama no processo de combustão (RABAÇAL, 2010; VIEIRA, 2012).

Os resíduos de palha de café e palha de feijão apresentaram maiores teores de cinzas, os quais não diferiram entre si estatisticamente, em contra partida, os resíduos madeireiros apresentaram os menores valores para esta variável, com destaque para a madeira de madeireira com $0,69 \%$. Os altos teores de cinzas observados principalmente nos resíduos de origem agrícola podem ter relação com a adubação das culturas. Brand (2010) afirma que é desejável que o combustível apresente baixas quantidades de cinzas, uma vez que altos teores de minerais contribuem para a redução do poder calorífico, visto que eles não participam do processo de combustão.

Segundo Vale et al. (2007), os elevados teores de cinzas estão relacionados com a presença de quantidades e de qualidades diferentes de minerais presentes na biomassa, tais como cálcio, potássio, fósforo, magnésio, ferro, sódio, entre outros, que fazem aumentar os teores de cinza. Segundo Vamvuka et al. (2014) esses elementos podem formar nas superfícies de troca térmica dos geradores de vapor severas deposições gerando escórias que podem levar ao mau funcionamento e reduzir a eficiência da transferência de calor. Além disso, as deposições podem gerar incrustações e corrosões que aceleram o desgaste das superfícies de troca térmica (DAYTON et al., 1999).

A palha de café apresentou o maior valor médio significativo para o teor de carbono fixo em relação aos demais resíduos, sendo que a madeira de construção civil, madeira de madeireira e o sabugo de milho não apresentam diferença significativa entre si. Segundo Brito e Barrichelo (1982) combustíveis com alto índice de carbono fixo apresentam queima mais lenta o que é vantajoso, devido ao maior tempo dentro das câmaras de combustão, em comparação com outros que tenham menor teor de carbono fixo.

Cieslinski (2014) estudando a emissão e controle dos gases e particulados provenientes da queima da biomassa encontrou para a casca de café valores de 73,6 e 19,9\% para teor de materiais voláteis e carbono fixo, respectivamente, valores similares foram encontrados neste trabalho.

A análise imediata da palha de feijão apresentou resultados distintos quando comparados com os valores determinados por Paula (2010) que estudou a produção e avaliação de briquetes de resíduos lignocelulósicos, onde encontrou valores de 76,65 e 
$18,10 \%$, para teor de voláteis e carbono fixo, respectivamente, para vagem de feijão e 77,53 e $18,75 \%$ para caule de feijão.

Os teores de materiais voláteis e carbono fixo obtidos para os resíduos madeireiros de construção civil e os resíduos madeireiros de serraria se encontram no intervalo determinado por Brito e Barrichello (1982), que preconizaram, em termos gerais, teores de matérias voláteis entre $75 \%$ a $85 \%$ e de carbono fixo entre $14 \%$ a $25 \%$ para a madeira. Porém, o teor de cinzas obtido para os resíduos de madeira de construção civil apresentaram um teor de $2,45 \%$ considerado um valor alto para madeira, que geralmente apresenta um teor de cinzas em torno de $1 \%$. O alto teor de cinzas pode ter ocorrido devido a impurezas contidas no material, as quais puderam ser observadas durante a coleta, como contato com solo, cimento, por se tratar de um material resultante de processos de construção e armazenado em locais abertos e próximos a estradas.

Os valores encontrados para a análise imediata do sabugo neste trabalho foram similares aos encontrados por Jenkins (1990) e Paula et al. (2011).

\subsubsection{Composição química}

Mediante a análise de componentes químicos, determina-se a composição de extrativos, teores de lignina, cinzas e holocelulose. Na Tabela 9 são apresentados os valores médios para os respectivos componentes.

Tabela 9. Análise química.

\begin{tabular}{|c|c|c|c|c|c|c|}
\hline CARACTERÍSTICAS & UNIDADE & $\mathrm{CA}$ & $\mathrm{FE}$ & $\mathrm{CC}$ & $\mathrm{MM}$ & SB \\
\hline \multirow{2}{*}{ Extrativos } & \multirow{2}{*}{$\%$} & 24,36 & 5,58 & 3,12 & 7,60 & 9,75 \\
\hline & & $(12,62)$ & $(15,75)$ & $(6,21)$ & $(2,49)$ & $(5,37)$ \\
\hline \multirow{2}{*}{ Lignina Total } & \multirow{2}{*}{$\%$} & 18,78 & 21,74 & 31,00 & 33,89 & 14,65 \\
\hline & & $(3,42)$ & $(2,06)$ & $(1,70)$ & $(6,91)$ & $(3,01)$ \\
\hline \multirow{2}{*}{ Cinzas } & \multirow{2}{*}{$\%$} & 3,22 & 2,50 & 1,57 & 0,73 & 1,23 \\
\hline & & $(12,60)$ & $(10,04)$ & $(8,35)$ & $(0,53)$ & $(0,91)$ \\
\hline \multirow{2}{*}{ Holocelulose } & \multirow{2}{*}{$\%$} & 53,64 & 70,17 & 64,31 & 57,79 & 74,37 \\
\hline & & $(3,97)$ & $(0,55)$ & $(0,87)$ & $(3,93)$ & $(0,53)$ \\
\hline
\end{tabular}

Observação: Valores entre parênteses correspondem aos coeficientes de variação. CA: palha de café. FE: palha de feijão. CC: madeira de construção civil. MM: madeira de madeireira. SB: sabugo de milho.

Na Tabela 10 estão os valores de "F" para o teor de extrativos, lignina total, cinzas e holocelulose. 
Tabela 10. Valores de "F" para o teor de extrativos (TE), lignina total (LT), cinzas (CZ) e holocelulose (HC).

\begin{tabular}{lcllll}
\hline \multirow{2}{*}{ FV } & GL & \multicolumn{4}{c}{ Valores de "F" } \\
\cline { 3 - 6 } & & TE & LT & CZ & HC \\
\hline Tratamentos & 4 & $99.0572 * *$ & $133.7686 * *$ & $131.0627 * *$ & $125.5940 * *$ \\
\hline Resíduo & 10 & & & \\
\hline Total & 14 & & & \\
\hline ** significativo ao nível de 1\% de probabilidade $(\mathrm{p}<.01)$ & & \\
$*$ * significativo ao nível de 5\% de probabilidade $(.01=<\mathrm{p}<.05)$ & \\
ns não significativo $(\mathrm{p}>=.05)$ &
\end{tabular}

Observa-se na tabela 10 que houve diferença significativa pelo Teste $\mathrm{F}$ nos valores das características analisadas, ou seja, pelo menos uma das médias das características analisadas para cada resíduo difere entre si estatisticamente, sendo necessário realizar o teste de média. O resultado do teste de Tukey é apresentado na Tabela 11.

Tabela 11. Teste de Tukey para as médias de teor de extrativos, lignina total, cinzas e holocelulose.

\begin{tabular}{ccccccc}
\hline CARACTERÍSTICAS & UNIDADE & CA & FE & CC & MM & SB \\
\hline Extrativos & $\%$ & $24,36 \mathbf{a}$ & $5,58 \mathbf{c d}$ & $3,12 \mathbf{d}$ & $7,60 \mathbf{b c}$ & $9,75 \mathbf{b}$ \\
\hline Lignina Total & $\%$ & $18,78 \mathbf{b}$ & $21,74 \mathbf{b}$ & $31,00 \mathbf{a}$ & $33,89 \mathbf{a}$ & $14,65 \mathbf{c}$ \\
\hline Cinzas* & $\%$ & $3,22 \mathbf{a}$ & $2,50 \mathbf{b}$ & $1,57 \mathbf{c}$ & $0,73 \mathbf{d}$ & $1,23 \mathbf{c d}$ \\
\hline Holocelulose & $\%$ & $53,64 \mathbf{e}$ & $70,17 \mathbf{b}$ & $64,31 \mathbf{c}$ & $57,79 \mathbf{d}$ & $74,37 \mathbf{a}$
\end{tabular}

Observação: Médias seguidas de mesma letra na linha não diferem entre si ao nível de 5\% de probabilidade. CA: palha de café. FE: palha de feijão. CC: madeira de construção civil. MM: madeira de madeireira. SB: sabugo de milho.

Pode-se observar, pelos dados da Tabela 11, que a palha de café apresentou o maior valor de extrativos, com 24,36\%, sendo superior a todos os resíduos avaliados, provavelmente devido ao teor de óleo contido no material. Os resultados obtidos neste trabalho estão de acordo com Brum (2007) que, estudando a caracterização e modificação química de resíduos sólidos do beneficiamento do café para produção de novos materiais, encontrou para a composição química da casca de café e polpa $26,00 \%$ de extrativos, $17,55 \%$ de lignina total e $52,50 \%$ de holocelulose.

Os resíduos madeireiros apresentaram a maior quantidade de lignina, com 31,00 e 
33,89\% para madeira de construção civil e madeira de madeireira, respectivamente. O alto teor de lignina observado nos resíduos madeireiros pode ser um ponto favorável para as propriedades energéticas do material. Segundo Jara (1989), o poder calorífico superior da madeira, além da umidade é muito influenciado pela constituição química, principalmente a lignina e extrativos. Para Brito e Barrichelo (1977), a carbonização de um material lignocelulósico rico em lignina produz um carvão com alto teor de carbono fixo. Isto se deve a maior resistência à decomposição térmica que a lignina tem em relação aos outros componentes dos materiais lignocelulósicos. Mori et al. (2002) e Trugilho et al. (2003), estudando a madeira de Eucalyptus, encontraram valores similares aos determinados neste trabalho.

Quanto ao teor de cinzas, observou-se que a biomassa agrícola apresentou, de maneira geral, valores superiores aos determinados para a biomassa de origem florestal.

O teor de holocelulose observado nos diferentes resíduos variou entre 53,64\% e $74,37 \%$. Como eram esperados, os maiores valores médios para a porcentagem de holocelulose foram observados nos resíduos de sabugo de milho e palha de feijão, exatamente aqueles que apresentaram menores valores para o teor de lignina, visto que se trata de uma relação inversa.

A porcentagem de holocelulose corresponde a uma parte da fração mais significativa da massa da biomassa e é representada pelos componentes estruturais que são os carboidratos. O comportamento da celulose e das hemiceluloses, diante da degradação térmica, apresenta um perfil bastante instável e pouco resistente, especialmente as hemiceluloses, por ser um composto que apresenta natureza amorfa e ramificada, colaborando para maior degradação. Com isso, altas porcentagens de holocelulose não são desejáveis quando se pretende utilizar a biomassa para fins energéticos (Santos, 2010).

A análise química do sabugo de milho corrobora com os resultados determinados por Paula (2010) que obteve valores de $15,75 \%$ para lignina, 77,24\% para holocelulose e 1,16\% para cinzas. Já Cruz et al. (2000) encontraram para análise química do sabugo de milho valores superiores para o teor de lignina, 20,30\%, e inferiores para o teor de holocelulose, 66,40\%. Segundo Brum (2007), deve-se levar em conta que a constituição química desses materiais depende de vários fatores, como constituição do solo, clima, época da colheita, infecções e pragas, método de plantio, entre outros, fazendo com que mesmo plantas de mesma espécie apresentem composições diferentes. 


\subsubsection{Análise elementar}

Na Tabela 12 são apresentados os resultados obtidos na análise elementar dos resíduos avaliados, carbono $(\mathrm{C})$, hidrogênio $(\mathrm{H})$, nitrogênio $(\mathrm{N})$, oxigênio $(\mathrm{O})$ e relação carbono-hidrogênio $(\mathrm{C} / \mathrm{H})$.

Tabela 12. Análise elementar dos resíduos in natura.

\begin{tabular}{ccccccc}
\hline \multirow{2}{*}{ ELEMENTOS } & \multirow{2}{*}{ UNIDADE } & \multicolumn{5}{c}{ Resíduos } \\
\cline { 3 - 7 } & & CA & FE & CC & MM & SB \\
\hline $\mathrm{C}$ & $\%$ & 42,33 & 40,65 & 45,98 & 48,54 & 40,49 \\
\hline $\mathrm{H}$ & $\%$ & 5,34 & 5,34 & 5,49 & 5,68 & 6,03 \\
\hline $\mathrm{N}$ & $\%$ & 1,66 & 1,90 & 0,22 & 0,26 & 1,42 \\
\hline $\mathrm{O} *$ & $\%$ & 50,67 & 52,03 & 48,31 & 45,52 & 52,06 \\
\hline $\mathrm{C} / \mathrm{H}$ & $\%$ & 7,93 & 7,61 & 8,37 & 8,54 & 6,71
\end{tabular}

* Obtido por diferença. CA: palha de café. FE: palha de feijão. CC: madeira de construção civil. MM: madeira de madeireira. SB: sabugo de milho.

Observa-se que os resíduos madeireiros apresentaram as maiores porcentagens de carbono (C). As porcentagens de hidrogênio $(\mathrm{H})$ apresentaram pouca variação entre os resíduos avaliados, sendo que o sabugo de milho, a madeira de madeireira e a madeira de construção civil apresentaram os maiores valores. Segundo Santos (2010) espera-se, para os materiais que têm maiores teores de carbono e hidrogênio, maior capacidade térmica em função da maior energia liberada por esses na reação de combustão. Essa tendência pode ser observada para os resíduos madeireiros, os quais possuem os maiores valores médios de carbono e hidrogênio e, consequentemente, apresentaram maior poder calorífico superior.

A composição elementar da madeira varia pouco com a espécie, podendo-se admitir que ela contenha, em base seca, cerca de 50\% de carbono, $6 \%$ de hidrogênio, $44 \%$ de oxigênio e entre 0,1 e 0,5\% de nitrogênio (BRITO e BARRICHELO, 1982), sem considerar traços de outros elementos. Independente de diferenças genéticas ou da idade, essa composição mantém-se aproximadamente constante, como pode ser observado neste estudo para os resíduos madeireiros. Obernberger et al. (2006) afirmam que o teor de carbono em combustíveis de madeira é superior ao de herbáceas, o que também foi observado no presente trabalho. 
Os maiores teores de oxigênio $(\mathrm{O})$ foram obtidos para os resíduos de feijão e sabugo de milho e o menor valor para a porcentagem desse elemento foi observado na madeira de serraria. De acordo com a Universidade Federal de Minas Gerais - UFMG (2010), a presença de oxigênio na biomassa oferece a desvantagem de diminuir seu valor como combustível.

Quanto aos teores de nitrogênio, Segundo Munalula \& Meincken (2009), altos teores de nitrogênio podem estar relacionados aos impactos ambientais e poluição do ar, em função da formação de óxidos de nitrogênio tóxicos e ácido nítrico.

Os maiores valores para a relação de $\mathrm{C} / \mathrm{H}$ encontrados foram para os resíduos madeireiros e o menor para sabugo de milho. Quanto maior esta relação melhor para a produção de energia, pois, segundo Warhurs et al. (1997), o aumento na relação C/H indica um aumento no grau de aromaticidade do material.

Os valores encontrados para a análise da casca do café, palha de feijão e sabugo de milho estão de acordo com os relatados por Brum et al. (2006), Oliveira et al. (2009) e Raveendran et al. (1995), respectivamente.

\subsubsection{Poder calorífico e densidade energética}

Na Tabela 13 estão apresentados os valores médios de poder calorífico superior (PCS), poder calorífico útil (PCU) e densidade energética (DE) para cada resíduo.

Tabela 13. Poder calorífico superior (PCS), poder calorífico útil (PCU) e densidade energética (DE).

\begin{tabular}{ccccccc}
\hline CARACTERÍSTICAS & \multirow{2}{*}{ UNIDADE } & CA & FE & CC & MM & SB \\
\hline \multirow{2}{*}{ PCS } & \multirow{2}{*}{$\mathrm{kcal} / \mathrm{kg}$} & 4369,29 & 4134,52 & 4612,97 & 4801,36 & 4317,24 \\
& & $(0,60)$ & $(0,92)$ & $(0,99)$ & $(0,93)$ & $(0,93)$ \\
\hline \multirow{2}{*}{$\mathrm{PCU}$} & \multirow{2}{*}{$\mathrm{kcal} / \mathrm{kg}$} & 3471,61 & 3462,39 & 3881,20 & $3,881,24$ & 3600,12 \\
& & $(1,68)$ & $(0,73)$ & $(0,24)$ & $(0,98)$ & $(1,76)$ \\
\hline \multirow{2}{*}{$\mathrm{DE}$} & \multirow{2}{*}{$\mathrm{Mcal} / \mathrm{m}^{3}$} & \multirow{2}{*}{$(351,09$} & 259,06 & 675,85 & 765,70 & 528,74 \\
& & $(0,04)$ & $(2,82)$ & $(3,30)$ & $(3,30)$ & $(1,43)$
\end{tabular}

Observação: Valores entre parênteses correspondem aos coeficientes de variação. CA: palha de café. FE: palha de feijão. CC: madeira de construção civil. MM: madeira de madeireira. SB: sabugo de milho.

Na Tabela 14 estão os valores de "F" para poder calorífico superior (PCS), poder calorífico útil (PCU) e densidade energética (DE). 
Tabela 14. Valores de "F" para poder calorífico superior (PCS), poder calorífico útil (PCU) e densidade energética (DE).

\begin{tabular}{lllll}
\hline \multirow{2}{*}{ FV } & \multirow{2}{*}{ GL } & \multicolumn{3}{c}{ Valores de “F” } \\
\cline { 3 - 5 } & & PCS & PCU & DE \\
\hline Tratamento & 4 & $131.4316 * *$ & $68.7695 * *$ & $3062.8657 * *$ \\
\hline Resíduo & 10 & & \\
\hline Total & 14 & & \\
** significativo ao nível de 1\% de probabilidade $(\mathrm{p}<.01)$ & & \\
$*$ significativo ao nível de 5\% de probabilidade $(.01=<\mathrm{p}<.05)$ & \\
ns não significativo $(\mathrm{p}>=.05)$ &
\end{tabular}

Observa-se na Tabela 14 que houve diferença significativa a 5\% pelo Teste $\mathrm{F}$ nos valores das características analisadas, ou seja, pelo menos uma das médias das características analisadas para cada resíduo difere entre si estatisticamente, sendo necessário realizar o teste de média. O resultado do teste de Tukey para poder calorífico superior (PCS), poder calorífico útil (PCU) e densidade energética (DE) é apresentado na Tabela 15.

Tabela 15. Teste de Tukey para as médias de poder calorifico superior (PCS), poder calorifico útil (PCU) e densidade energética (DE).

\begin{tabular}{ccccccc}
\hline CARACTERÍSTICAS & UNIDADE & CA & FE & CC & MM & SB \\
\hline PCS & $\mathrm{kcal} / \mathrm{kg}$ & $4369,29 \mathbf{c}$ & $4134,52 \mathbf{d}$ & $4612,97 \mathbf{b}$ & $4801,36 \mathbf{a}$ & $4317,24 \mathbf{c}$ \\
\hline PCU & $\mathrm{kcal} / \mathrm{kg}$ & $3471,61 \mathbf{c}$ & $3462,39 \mathbf{c}$ & $3881,20 \mathbf{a}$ & $3,881,24 \mathbf{a}$ & $3600,12 \mathbf{b}$ \\
\hline DE & $\mathrm{kcal} / \mathrm{m}^{3}$ & $1351,09 \mathbf{a}$ & $259,06 \mathbf{e}$ & $675,85 \mathbf{c}$ & $765,70 \mathbf{b}$ & $528,74 \mathbf{d}$
\end{tabular}

Observação: Médias seguidas de mesma letra na linha não diferem entre si ao nível de 5\% de probabilidade. CA: palha de café. FE: palha de feijão. CC: madeira de construção civil. MM: madeira de madeireira. SB: sabugo de milho.

O resíduo que apresentou maior poder calorífico superior foi a madeira de madeireira com 4801,36 kcal/kg, contudo, a palha de café apesar de ter um poder calorífico superior menor que os resíduos madeireiros, possui uma densidade do granel maior, implicando em maior produção de energia por unidade volumétrica, otimizando assim o uso em aparelhos de queima. Ensaios realizados por Pinheiro et al., (2006) indicaram que o parâmetro que influenciou de maneira mais expressiva a densidade energética dos resíduos foi a densidade a granel dos mesmos, com ressalvas ao teor de umidade. 
Todavia, com exceção da palha de café, todas as demais biomassas estudadas apresentaram baixa densidade energética. Protásio et al. (2011) trabalharam com a compactação de biomassa vegetal visando a produção de biocombustíveis sólidos e reafirmam que os resíduos in natura apresentam baixa densidade energética.

O poder calorífico é um excelente parâmetro para se avaliar a potencialidade energética de combustíveis de biomassa (Protásio et al., 2011; Brand, 2010; Friedl et al., 2005). Nesse sentido, uma tonelada de palha de café tem um poder energético 4.369.290 kcal e pode ser utilizado como biocombustível não só para gerar calor em fornalhas, como também gerar energia elétrica em pequenas comunidades, onde a produção desse resíduo seja significativa. Na ilha de Cuba isso já é uma realidade, segundo Suarez \& Luengo (2003), que registrou o uso da casca de café para produção de energia, indicando que, nos países em desenvolvimento, a biomassa de resíduo agrícola pode se transformar numa importante fonte energética para as comunidades.

Vale et al. (2007) estudando a carbonização de resíduos do processamento do café, encontrou para casca o valor de poder calorífico superior de $3.933(\mathrm{kcal} / \mathrm{kg})$ e poder calorífico útil de $3.040(\mathrm{kcal} / \mathrm{kg})$, com $13,5 \%$ de umidade, resultados inferiores ao valor médio encontrado neste trabalho. Já Protásio et al. (2011) determinaram um poder calorifico superior de $4.403,33 \mathrm{kcal} / \mathrm{kg}$ próximo aos relatados no presente trabalho.

A palha de feijão apresentou o menor valor de poder calorífico superior valor que associado a baixa densidade do granel resultou na menor densidade energética obtida. Paula et al. (2011) determinaram para o caule e a vagem de feijão um poder calorífico superior de $4.488,74$ e $4.218,53 \mathrm{kcal} / \mathrm{kg}$, respectivamente, valor similar ao determinado neste trabalho.

O poder calorífico superior dos resíduos madeireiros se encaixam nos intervalos determinados por Brito \& Barrichello (1978) e Brito (1993) para madeira seca, sendo de 4.000 a $4.800 \mathrm{kcal} / \mathrm{kg}$. O poder calorífico do sabugo está de acordo com Jenkins (1990).

A carbonização e a briquetagem desses resíduos podem ser alternativas para melhorar sua qualidade e comercialização uma vez que, segundo Prins et al. (2006) tratamentos térmicos da biomassa resultam em aumento da densidade energética e diminuição da umidade. 


\subsection{Caracterização das propriedades do carvão}

\subsubsection{Perfil térmico}

O ciclo de carbonização dos resíduos teve duração média de 13 h, sendo 8 h para carbonização dos resíduos e $5 \mathrm{~h}$ para o resfriamento do forno. Porém apesar de programada uma taxa de resfriamento do forno, o resfriamento ocorreu de maneira natural, mediante a simples troca de calor do forno com o ambiente. A retirada do carvão vegetal ocorreu quando a temperatura interna atingiu uma média inferior a $40{ }^{\circ} \mathrm{C}$, temperatura que assegura a abertura do forno e retirada do carvão vegetal sem riscos de incêndio. As Figuras 19 e 20 representam o comportamento da carbonização dos resíduos ao longo do tempo.

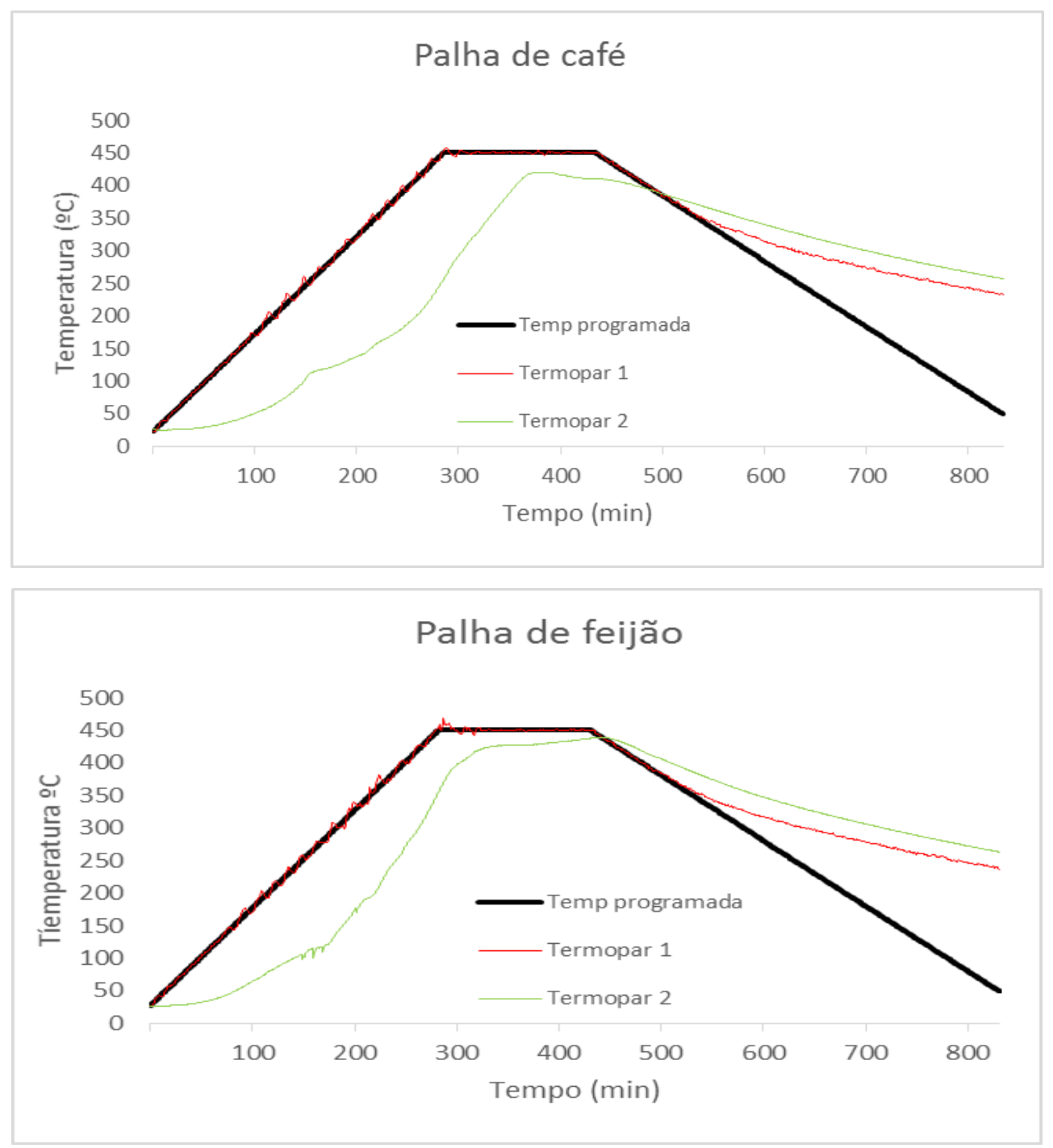

Figura 19. Perfis de carbonização para palha de café e palha de feijão 

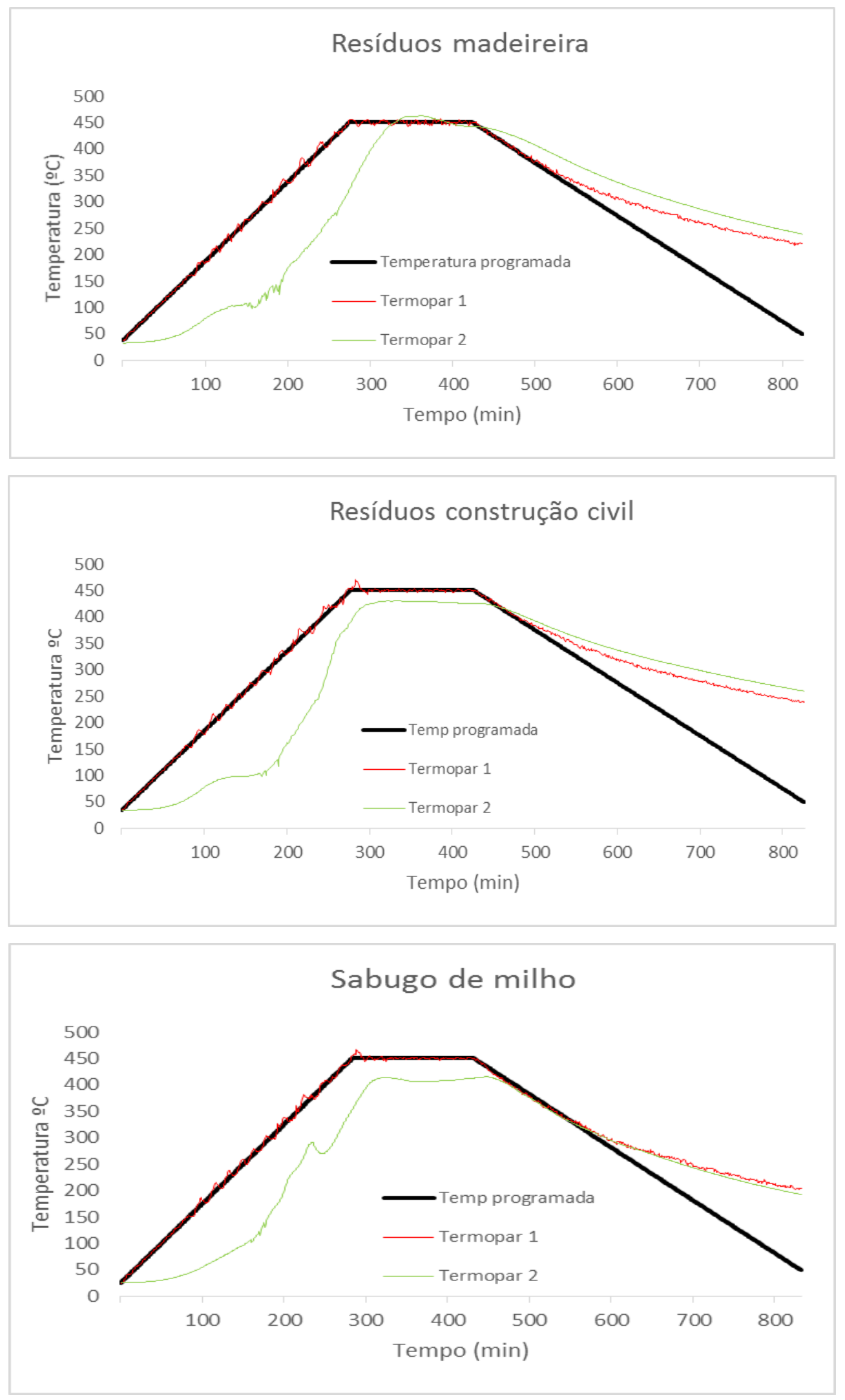

Figura 20. Perfis de carbonização para os resíduos de madeireira, resíduos de construção civil e sabugo de milho 
Arruda et al. (2011) ressaltaram que a determinação da temperatura interna do forno permite a obtenção do perfil térmico da carbonização e do resfriamento condizentes com os fenômenos que realmente ocorrem. Essas informações são utilizadas para o melhor controle dos processos, resultando em maior rendimento gravimétrico da carbonização e melhoria da qualidade do carvão vegetal.

Conforme observado nas Figuras 19 e 20, durante a carbonização foram observadas três fases distintas. Primeira fase, caracterizada pelo aquecimento e secagem da carga, onde a temperatura máxima pode variar de $110-150^{\circ} \mathrm{C}$. Segunda fase, a variação de temperatura compreende a faixa de $150-450^{\circ} \mathrm{C}$ quando ocorre o processo de carbonização. Terceira fase, a redução da temperatura interna do forno indica o fim da carbonização e início do processo de resfriamento do forno.

Nota-se ainda a influência do teor de umidade dos resíduos no processo de produção de carvão vegetal. Quanto maior o teor de umidade, mais lenta é a taxa de aquecimento, e a temperatura, em alguns casos torna-se inconstante devido ao excesso de vapor de água liberado.

\subsubsection{Rendimentos do carvão}

Os valores obtidos para o rendimento da carbonização para os carvões dos cinco resíduos agroflorestais, palha de café, palha de feijão, madeira de construção civil, madeira de serraria e sabugo de milho, estão detalhados nas Tabela 16. As médias dos teores de umidade e dos rendimentos foram analisadas pelo teste de Tukey a 5\% de probabilidade (Tabela 17).

Tabela 16. Rendimento gravimétrico da carbonização dos resíduos.

\begin{tabular}{ccccccc}
\hline CARACTERÍSTICAS & UNIDADE & CA & FE & CC & MM & SB \\
\hline \multirow{2}{*}{ TU } & \multirow{2}{*}{$\%$} & 25,95 & 16,89 & 9,49 & 9,09 & 13,25 \\
& & $(4,26)$ & $(1,73)$ & $(4,21)$ & $(4,36)$ & $(6,24)$ \\
\hline \multirow{2}{*}{ RGC } & \multirow{2}{*}{$\%$} & 41,04 & 39,95 & 40,57 & 38,53 & 39,20 \\
& & $(2,06)$ & $(0,62)$ & $(1,49)$ & $(1,22)$ & $(1,95)$ \\
\hline
\end{tabular}

Obs: Valores entre parênteses correspondem aos coeficientes de variação. CA: palha de café. FE: palha de feijão. CC: madeira de construção civil. MM: madeira de madeireira. SB: sabugo de milho.

Observa-se na Tabela 17 o valor de F, para o rendimento gravimétrico em carvão vegetal, significativo ao nível de $1 \%$ de probabilidade. O resultado do teste de Tukey para o RGC é apresentado na Tabela 18. 
Tabela 17. Valor de "F" para rendimento gravimétrico do carvão.

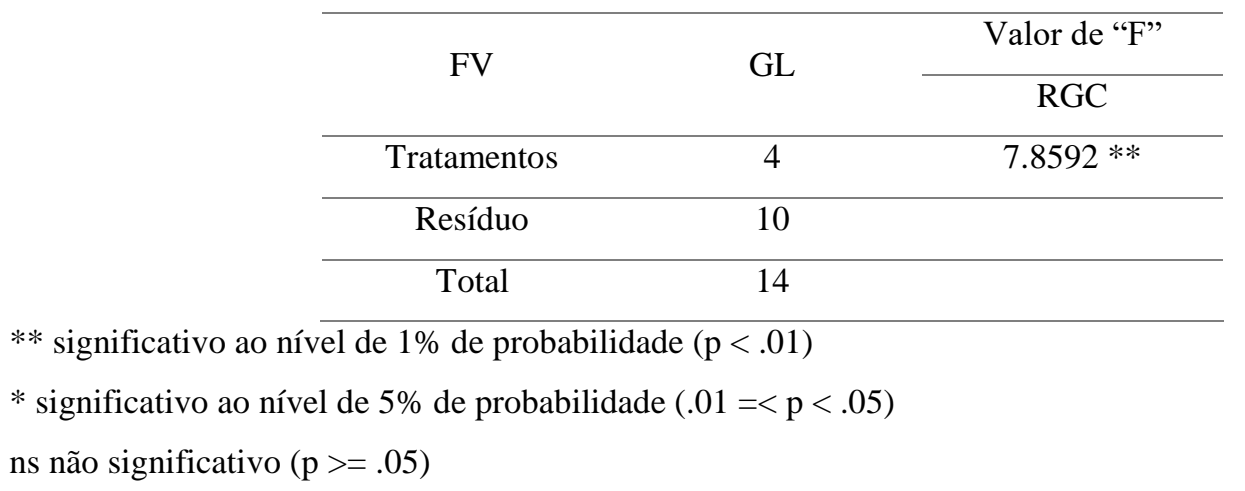

Tabela 18- Teste de tukey para rendimento gravimétrico do carvão (RGC).

\begin{tabular}{ccccccc}
\hline CARACTERÍSTICAS & UNIDADE & CA & FE & CC & MM & SB \\
\hline RGC & $\%$ & $41,04 \mathbf{a}$ & $39,95 \mathbf{a b c}$ & $40,57 \mathbf{a b}$ & $38,53 \mathbf{c}$ & $39,20 \mathbf{b c}$
\end{tabular}

Obs: as médias seguidas pela mesma letra não diferem estatisticamente entre si na mesma linha. CA: palha de café. FE: palha de feijão. CC: madeira de construção civil. MM: madeira de madeireira. SB: sabugo de milho.

A produção de carvão vegetal em sistemas autotérmicos utilizando-se madeira de eucalipto, segundo Brito \& Barrichelo (1981) apresenta rendimento gravimétrico entre $25 \%$ e $35 \%$ com base na madeira seca. Em sistemas alotérmicos, como é o caso de retortas elétricas, via de regra, os rendimentos são maiores, uma vez que não há consumo de parte da carga para gerar energia para a carbonização, como ocorre no primeiro caso.

Sater et al. (2011) ao realizarem um estudo comparativo da carbonização de resíduos agrícolas e florestais visando à substituição da lenha no processo de secagem de grãos de café concluíram que os resíduos de casca de café proporcionaram boa produção de carvão vegetal, visto que seus rendimentos gravimétricos em carvão foram superiores aos dos demais tratamentos (lenha de Eucalyptus grandis e resíduos da fresa), sendo 40,58; 29,87 e $31,83 \%$, respectivamente. Entretanto, todos os carvões mostram grande potencial para ser utilizado como insumo energético na secagem artificial de café. Vale et al. (2007) também encontrou um alto rendimento em carvão de casca de café, 40,64\%.

Paes et al. (2012) estudaram o rendimento e caracterização do carvão vegetal de três espécies de ocorrência no semiárido brasileiro e também encontraram altos rendimentos gravimétricos, variando de 39,42 a 40,98\%. Trugilho et al. (2005), trabalhando com seis clones de híbridos de Eucalyptus aos 7 anos de idade, obtiveram uma variação de $35,95 \%$ a 40,24\% no rendimento gravimétrico em carvão vegetal, valores semelhantes aos encontrados neste trabalho para os resíduos madeireiros. 


\subsubsection{Análise elementar}

Os valores médios da análise elementar dos carvões dos diferentes resíduos avaliados são mostrados na Tabela 19.

Tabela 19. Análise elementar dos carvões dos resíduos.

\begin{tabular}{ccccccc}
\hline \multirow{2}{*}{ ELEMENTOS } & \multirow{2}{*}{ UNIDADE } & \multicolumn{5}{c}{ Resíduos } \\
\cline { 3 - 7 } & & CA & FE & CC & MM & SB \\
\hline $\mathrm{C}$ & $\%$ & 61,94 & 54,82 & 75,64 & 73,32 & 71,64 \\
\hline $\mathrm{H}$ & $\%$ & 3,70 & 3,03 & 3,46 & 3,61 & 3,40 \\
\hline $\mathrm{N}$ & $\%$ & 3,05 & 2,32 & 0,36 & 0,43 & 1,23 \\
\hline $\mathrm{O} *$ & $\%$ & 31,31 & 39,83 & 20,54 & 22,64 & 23,73 \\
\hline $\mathrm{C} / \mathrm{H}$ & $\%$ & 16,74 & 18,09 & 21,86 & 20,31 & 21,07
\end{tabular}

Obs: CA: palha de café. FE: palha de feijão. CC: madeira de construção civil. MM: madeira de madeireira. SB: sabugo de milho.

A quantificação dos componentes químicos elementares é importante na caracterização de um biocombustível sólido, pois a energia liberada durante o processo de combustão está correlacionada de forma positiva com os teores em carbono e hidrogênio e, de forma contrária, com o teor em oxigênio (Senelwa \& Sims, 1999; Obernberger et al., 2006; Huang et al., 2009; Protásio et al., 2011a).

Os carvões de resíduos de madeira apresentaram os maiores valores de carbono elementar, 75,64 e 73,32\%, para madeira de construção civil e madeireira, respectivamente, enquanto que a palha de café apresentou o maior valor de hidrogênio, 3,70\%. A palha de feijão apresentou o maior teor de oxigênio, 39,83\%.

Oliveira et al. (2010), ao analisarem as propriedades químicas elementares do carvão vegetal produzido a partir de clones de Eucalyptus pellita aos 5 anos de idade, encontraram 76,92\% de carbono, 2,63\% de hidrogênio, 0,41\% de nitrogênio e 20,04\% de oxigênio, utilizando marcha de carbonização similar.

O nitrogênio está diretamente relacionado com a emissão de componentes NOx (óxidos de nitrogênio tóxicos), corrosão e deposição de cinzas (Demirbas, 2004).

Nos resultados da análise elementar foi possível perceber que a carbonização proporcionou uma maior concentração de carbono e diminuiu a quantidade de oxigênio e hidrogênio devido à perda de massa ocasionada pelo tratamento térmico, quando 
comparado com os resíduos "in natura". Entretanto, a perda de massa é compensada pelo ganho energético em carbono, que acompanha o aumento no poder calorífico.

\subsubsection{Análise imediata}

Os resultados encontrados na análise imediata para o carvão dos resíduos estudados estão apresentados na Tabela 20.

Tabela 20. Análise imediata.

\begin{tabular}{ccccccc}
\hline CARACTERÍSTICAS & UNIDADE & CA & FE & CC & MM & SB \\
\hline \multirow{2}{*}{ MV } & \multirow{2}{*}{$\%$} & 30,11 & 31,07 & 24,06 & 25,04 & 24,70 \\
& & $(0,88)$ & $(5,57)$ & $(4,61)$ & $(13,12)$ & $(12,49)$ \\
\hline \multirow{2}{*}{ CZ } & \multirow{2}{*}{$\%$} & 8,27 & 21,57 & 3,55 & 1,42 & 8,24 \\
& \multirow{2}{*}{ CF } & $(20,95)$ & $(3,56)$ & $(1,54)$ & $(7,78)$ & $(20,59)$ \\
& \multirow{2}{*}{ $\%$} & 61,62 & 47,36 & 72,39 & 73,53 & 66,97 \\
\multirow{2}{*}{ RCF } & \multirow{2}{*}{$\%$} & $(2,57)$ & $(2,10)$ & $(1,60)$ & $(4,35)$ & $(3,93)$ \\
\hline
\end{tabular}

Obs: Valores entre parênteses correspondem aos coeficientes de variação. CA: palha de café. FE: palha de feijão. CC: madeira de construção civil. MM: madeira de madeireira. SB: sabugo de milho.

Na Tabela 21 estão os valores de "F" para o teor de materiais voláteis, teor de cinzas e teor de carbono fixo.

Tabela 21. Valores de "F" para teor de materiais voláteis (MV), teor de cinzas (CZ) e teor de carbono fixo $(\mathrm{CF})$.

\begin{tabular}{llllll}
\hline \multirow{2}{*}{ FV } & \multirow{2}{*}{ GL } & \multicolumn{4}{c}{ Valores de "F" } \\
\cline { 3 - 6 } & & MV & CZ & CF & RCF \\
\hline Tratamentos & 4 & $6.6199 * *$ & $141.7608 * *$ & $77.1423 * *$ & $88.6359 * *$ \\
\hline Resíduo & 10 & & & \\
\hline Total & 14 & & & \\
\hline$* *$ significativo ao nível de $1 \%$ de probabilidade $(\mathrm{p}<.01)$ & \\
$*$ significativo ao nível de 5\% de probabilidade $(.01=<\mathrm{p}<.05)$ \\
ns não significativo $(\mathrm{p}>=.05)$
\end{tabular}

Observa-se na Tabela 21 que houve diferença significativa pelo Teste F nos valores das características analisadas, sendo necessário realizar o teste de média. O resultado do teste de Tukey para MV, CZ, CF e RCF é apresentado na Tabela 22. 
Tabela 22. Teste Tukey da análise imediata.

\begin{tabular}{ccccccc}
\hline CARACTERÍSTICAS & UNIDADE & CA & FE & CC & MM & SB \\
\hline MV & $\%$ & $30,11 \mathbf{a b}$ & $31,07 \mathbf{a}$ & $24,06 \mathbf{c}$ & $25,04 \mathbf{b c}$ & $24,7 \mathbf{b c}$ \\
\hline CZ & $\%$ & $8,27 \mathbf{b}$ & $21,57 \mathbf{a}$ & $3,55 \mathbf{c}$ & $1,42 \mathbf{c}$ & $8,24 \mathbf{b}$ \\
\hline CF & $\%$ & $61,62 \mathbf{c}$ & $47,36 \mathbf{d}$ & $72,39 \mathbf{a b}$ & $73,53 \mathbf{a}$ & $66,97 \mathbf{b c}$ \\
\hline RCF & $\%$ & $25,30 \mathbf{b}$ & $18,92 \mathbf{c}$ & $29,37 \mathbf{a}$ & $28,32 \mathbf{a}$ & $26,24 \mathbf{b}$ \\
\hline
\end{tabular}

Obs: as médias seguidas pela mesma letra não diferem estatisticamente entre si na mesma linha. CA: palha de café. FE: palha de feijão. CC: madeira de construção civil. MM: madeira de madeireira. SB: sabugo de milho. RCF: rendimento do carbono fixo.

O menor valor em materiais voláteis no carvão vegetal quando comparado com a biomassa in natura se deve ao fato de ser uma fonte secundária de energia, e, no processo de carbonização ter sofrido uma degradação térmica, com eliminação de parte dos materiais voláteis.

O carvão derivado da palha de feijão, palha de café e sabugo apresentaram teores de cinzas elevados, podendo ser justificado pela adubação das culturas. Além disso, alto teor de cinzas resulta na diminuição do poder calorífico do combustível. Se o carvão vegetal for utilizado diretamente em caldeiras ou gaseificadores para a geração de bioenergia, ou seja, por tecnologias termoquímicas, especialmente combustão, o alto teor de cinzas é desvantajoso porque diminui a transferência de calor no combustível e aumenta a corrosão dos equipamentos utilizados no processo (Brand, 2010; Tan \& Lagerkvist, 2011). Todavia, o alto teor de cinzas não é um empecilho para seu uso como combustível.

Observou-se ainda que o teor de cinzas apresentou o maior coeficiente de variação (20,95\%), uma vez que essa característica tende a apresentar maior variabilidade no combustível devido à sua pequena quantidade percentual, quando comparada aos outros constituintes químicos do carvão vegetal.

O teor de carbono fixo, dos resíduos madeireiros e do sabugo de milho foram estatisticamente maiores que aqueles obtidos a partir do carvão da palha de café e palha de feijão, no entanto, nenhuma biomassa atingiu a faixa desejada de carbono fixo para uso siderúrgico que segundo Santos (2008) está entre 75 e $80 \%$.

O rendimento em carbono fixo dos resíduos madeireiros apresentaram valores estatisticamente superiores aos demais resíduos. Andrade (1989) afirmou que o rendimento em carbono fixo é o parâmetro que melhor expressa a qualidade energética da matériaprima lignocelulósica, para a produção de carvão vegetal.

Além disso, quanto maior o teor de carbono fixo e menor o teor de materiais 
voláteis do carvão vegetal, maior será o seu valor calórico (Trugilho \& Silva, 2001; Lima et al., 2011; Protásio et al., 2011b). Segundo Protásio et al. (2011b) a cada 1\% de acréscimo no teor de carbono fixo ocorre um aumento de aproximadamente $73 \mathrm{kcal} / \mathrm{kg}$ no poder calorífico superior do carvão vegetal de Qualea parviflora, considerando a mesma temperatura final de carbonização e taxa de aquecimento utilizada nesse trabalho. Os autores ainda mencionam que a cada $1 \%$ de acréscimo no teor de materiais voláteis ocorre um decréscimo de $72 \mathrm{kcal} / \mathrm{kg}$ no poder calorífico superior do carvão vegetal dessa espécie.

\subsubsection{Poder calorífico, densidade do granel e densidade energética}

A Tabela 23 apresenta os valores médios obtidos para a variável poder calorífico superior, poder calorífico útil, densidade do granel e densidade energética do carvão.

Tabela 23. Poder calorífico superior, poder calorífico útil, densidade do granel e densidade energética do carvão.

\begin{tabular}{ccccccc}
\hline CARACTERÍSTICAS & \multirow{2}{*}{ UNIDADE } & CA & FE & CC & MM & SB \\
\hline \multirow{2}{*}{ Poder Calorífico Superior } & \multirow{2}{*}{$\mathrm{kcal} / \mathrm{kg}$} & $\begin{array}{l}6366,97 \\
(1,27)\end{array}$ & $\begin{array}{l}5548,08 \\
(1,21)\end{array}$ & $\begin{array}{c}7092,12 \\
(0,62)\end{array}$ & $\begin{array}{c}7006,2 \\
(3,34)\end{array}$ & $\begin{array}{l}6540,62 \\
(1,91)\end{array}$ \\
\hline \multirow{2}{*}{ Poder Calorífico Útil } & \multirow{2}{*}{$\mathrm{kcal} / \mathrm{kg}$} & $\begin{array}{c}5822,87 \\
(1,60)\end{array}$ & $\begin{array}{c}5049,72 \\
(0,90)\end{array}$ & $\begin{array}{c}6620,50 \\
(3,65)\end{array}$ & $\begin{array}{c}6690,58 \\
(0,69)\end{array}$ & $\begin{array}{c}6079,79 \\
(1,94)\end{array}$ \\
\hline \multirow{2}{*}{ Densidade do granel } & \multirow{2}{*}{$\mathrm{kg} / \mathrm{m}^{3}$} & $\begin{array}{c}162,49 \\
(3,22)\end{array}$ & $\begin{array}{c}125,35 \\
(2,26)\end{array}$ & $\begin{array}{c}171,74 \\
(2,87)\end{array}$ & $\begin{array}{c}170,04 \\
(1,64)\end{array}$ & $\begin{array}{c}114,33 \\
(1,33)\end{array}$ \\
\hline \multirow{2}{*}{ Densidade Energética } & \multirow{2}{*}{$\mathrm{Ncal} / \mathrm{m}^{3}$} & $\begin{array}{c}945,92 \\
(2,47)\end{array}$ & $\begin{array}{c}632,93 \\
(1,98)\end{array}$ & $\begin{array}{c}1136,74 \\
(3,85)\end{array}$ & $\begin{array}{c}1137,61 \\
(1,11)\end{array}$ & $\begin{array}{c}695,01 \\
(0,68)\end{array}$ \\
\hline
\end{tabular}

Obs: Valores entre parênteses correspondem aos coeficientes de variação. CA: palha de café. FE: palha de feijão. CC: madeira de construção civil. MM: madeira de madeireira. SB: sabugo de milho.

$\mathrm{Na}$ Tabela 24 estão os valores de "F" para poder calorífico superior (PCS), poder calorífico útil (PCU) e densidade energética (DE).

Tabela 24. Valores de "F" para poder calorífico superior (PCS), poder calorífico útil (PCU) e densidade energética (DE).

\begin{tabular}{llllll}
\hline \multirow{2}{*}{ FV } & \multirow{2}{*}{ GL } & \multicolumn{4}{c}{ Valores de "F" } \\
\cline { 3 - 6 } & & PCS & PCU & DG & DE \\
\hline Tratamento & 4 & $68.9899 * *$ & $78.8992 * *$ & $155.6818 * *$ & $304.6891 * *$ \\
\hline Resíduo & 10 & & & \\
\hline Total & 14 & & & \\
\hline$* *$ significativo ao nível de $1 \%$ de probabilidade $(\mathrm{p}<.01)$ & \\
$*$ significativo ao nível de 5\% de probabilidade $(.01=<\mathrm{p}<.05)$ \\
ns não significativo $(\mathrm{p}>=.05)$
\end{tabular}


Observa-se na tabela 24 que houve diferença significativa pelo Teste F nos valores das características analisadas, sendo necessário realizar o teste de média. O resultado do teste de Tukey para PCS, PCU, DE é apresentado na Tabela 25.

Tabela 25. Teste de Tukey poder calorífico superior (PCS), poder calorífico útil (PCU), densidade do grandel (Dg) e densidade energética (DE).

\begin{tabular}{ccccccc}
\hline CARACTERÍSTICAS & UNIDADE & CA & FE & CC & MM & SB \\
\hline Poder Calorífico Superior & $\mathrm{kcal} / \mathrm{kg}$ & $6366,97 \mathbf{b}$ & $5548,08 \mathbf{c}$ & $7092,12 \mathbf{a}$ & $7006,2 \mathbf{a}$ & $6540,62 \mathbf{b}$ \\
\hline Poder Calorífico Útil & $\mathrm{kcal} / \mathrm{kg}$ & $5822,87 \mathbf{b}$ & $5049,72 \mathbf{c}$ & $6620,50 \mathbf{a}$ & $6690,58 \mathbf{a}$ & $6079,79 \mathbf{b}$ \\
\hline Densidade do granel & $\mathrm{kg} / \mathrm{m}^{3}$ & $162,49 \mathbf{a}$ & $125,35 \mathbf{b}$ & $171,74 \mathbf{a}$ & $170,04 \mathbf{a}$ & $114,33 \mathbf{c}$ \\
\hline Densidade Energética & $\mathrm{Mcal} / \mathrm{m}^{3}$ & $945,92 \mathbf{b}$ & $632,93 \mathbf{c}$ & $1136,74 \mathbf{a}$ & $1137,61 \mathbf{a}$ & $695,01 \mathbf{c}$ \\
\hline
\end{tabular}

Obs: as médias seguidas pela mesma letra não diferem estatisticamente entre si na mesma linha. CA: palha de café. FE: palha de feijão. CC: madeira de construção civil. MM: madeira de madeireira. SB: sabugo de milho.

Em relação ao conteúdo energético, a biomassa quando carbonizada apresenta um aumento no poder calorífico devido à modificação das substâncias químicas que a compõem, tornando-se mais energética. Para a palha de feijão, o aumento no PCS não foi muito significativo devido à elevada quantidade de cinzas presentes na biomassa.

Foi possível verificar que não houve diferença significativa entre os valores de poder calorífico dos resíduos de madeira de construção civil e madeireira e entre os resíduos de palha de café e sabugo de milho, pelo teste de tukey a 5\% de probabilidade. Os maiores valores de poder calorífico superior foram encontrados para os resíduos madeireiros os quais apresentaram os maiores valores de carbono fixo, em relação às diferentes matérias-primas estudadas. Essa relação está de acordo com Tienne et al. (2004) que afirmam que o poder calorífico superior (PCS) tem relação direta com o teor de carbono fixo do carvão vegetal.

Os maiores valores para poder calorífico associado aos maiores valores de densidade do granel resultaram na maior densidade energética para os resíduos madeireiros. Dessa forma, os resultados evidenciaram que o carvão dos resíduos madeireiros apresentou melhor qualidade, quando comparado com as demais matériasprimas estudadas. 


\subsection{Caracterização das propriedades dos briquetes}

\subsubsection{Teor de umidade, densidade aparente e resistência a compressão paralela}

A Tabela 26 apresenta os valores médios das umidades de equilíbrio higroscópico após a secagem ao ar e a estabilização com a umidade ambiental, densidade aparente e resistência a compressão paralela.

Tabela 26. Valores médios das umidades, densidade aparente e resistência a compressão paralela.

\begin{tabular}{cccc}
\hline Tratamentos & $\begin{array}{c}\text { Umidade } \\
(\%)\end{array}$ & $\begin{array}{c}\mathrm{Da} \\
\left(\mathrm{g} / \mathrm{cm}^{3}\right)\end{array}$ & $\begin{array}{c}\mathrm{RCP} \\
(\mathrm{kgf})\end{array}$ \\
\hline T1 (M-50-60/40) & 6,77 & 0,52 & 43,80 \\
& $(1,31)$ & $(0,90)$ & $(23,67)$ \\
T2 (M-50-70/30) & 6,39 & 0,50 & 20,60 \\
& $(2,67)$ & $(1,63)$ & $(7,57)$ \\
T3(M-100-60/40) & 7,05 & 0,57 & 81,03 \\
& $(2,13)$ & $(0,83)$ & $(7,04)$ \\
T4(M-100-70/30) & 6,66 & 0,53 & 37,60 \\
& $(2,26)$ & $(0,00)$ & $(8,85)$ \\
T5(S-50-60/40) & 6,82 & 0,51 & 42,07 \\
& $(1,95)$ & $(2,77)$ & $(25,38)$ \\
T6(S-50-70/30) & 6,49 & 0,49 & 18,03 \\
& $(2,28)$ & $(0,97)$ & $(15,39)$ \\
T7(S-100-60/40) & 6,73 & 0,54 & 62,67 \\
& $(3,30)$ & $(0,88)$ & $(12,99)$ \\
T8(S-100-70/30) & 6,52 & 0,51 & 40,23 \\
& $(0,84)$ & $(0,93)$ & $(16,46)$ \\
\hline
\end{tabular}

Obs: M e S - aglutinantes de milho e sorgo; 50 e 100 - pressão em kgf/ $\mathrm{cm}^{2} ; 60 / 40$ e 70/30 - mistura de carvão/aglutinante. Valores entre parênteses correspondem ao coeficiente de variação.

A densidade aparente é uma característica importante na avaliação dos briquetes, pois maiores densidades indicam mais massa disponível para um mesmo volume considerado e consequentemente maior densidade energética.

$\mathrm{Na}$ Tabela 26, verifica-se que o maior valor de densidade aparente foi de $0,57 \mathrm{~g} / \mathrm{cm}^{3}$ para os briquetes produzidos com o aglutinante de resíduos de milho na proporção de 60/40 (carvão/aglutinante), e pressão de $100 \mathrm{kgf} / \mathrm{cm}^{2}$. As demais densidades aparentes, apresentaram valores que oscilaram de 0,49 a $0,54 \mathrm{~g} / \mathrm{cm}^{3}$. De forma geral, o que se pode 
perceber é que, mesmo que de maneira discreta, a densidade aparente dos briquetes aumentou nos tratamentos com maior pressão. A Tabela 27 contém os valores de "F" para umidade de equilíbrio e densidade aparente.

Tabela 27. Valores de "F" para umidade de equilíbrio e densidade aparente.

\begin{tabular}{llll}
\hline \multirow{2}{*}{ FV } & \multirow{2}{*}{ GL } & \multicolumn{2}{c}{ Valores de "F" } \\
\cline { 3 - 4 } & & $\mathrm{U}$ & $\mathrm{Da}$ \\
\hline Aglutinante & 1 & $4,31 *$ & $42,33 * *$ \\
\hline Pressão & 1 & $10,52 * *$ & $154,80 * *$ \\
\hline Mistura & 1 & $74,87 * *$ & $160,53 * *$ \\
\hline Aglu x Pres & 1 & $16,46 * *$ & $12,51 * *$ \\
\hline Aglu x Mist & 1 & $2,76 \mathrm{~ns}$ & $3,76 \mathrm{~ns}$ \\
\hline Pres x Mist & 1 & $0,56 \mathrm{~ns}$ & $3,76 \mathrm{~ns}$ \\
\hline Aglu x Pres x Mist & 1 & $0,75 \mathrm{~ns}$ & $0,12 \mathrm{~ns}$ \\
\hline Resíduo & 64 & & \\
\hline Total & 71 & &
\end{tabular}

** significativo ao nível de $1 \%$ de probabilidade $(\mathrm{p}<.01)$

* significativo ao nível de $5 \%$ de probabilidade $(.01=<\mathrm{p}<.05)$

ns não significativo $(\mathrm{p}>=.05)$

Conforme se observa na Tabela 27 apenas a interação Aglutinante x Pressão é significativa a $1 \%$ de probabilidade, tanto para umidade de equilíbrio quanto densidade aparente. As Tabelas 28 e 29 apresentam o desdobramento da análise estatística.

Tabela 28. Análise da interação pressão x aglutinante.

\begin{tabular}{|c|c|c|c|}
\hline \multicolumn{4}{|c|}{ Pressão dentro do aglutinante 1 (milho) } \\
\hline $\begin{array}{l}\text { Pressão } \\
\left(\mathrm{kgf} / \mathrm{cm}^{2}\right)\end{array}$ & $\begin{array}{l}\text { Umidade } \\
(\%)\end{array}$ & $\begin{array}{c}\text { Pressão } \\
\left(\mathrm{kgf} / \mathrm{cm}^{2}\right)\end{array}$ & $\begin{array}{c}\text { Densidade } \\
\left(\mathrm{g} / \mathrm{cm}^{3}\right)\end{array}$ \\
\hline $1-50$ & $6,58 \mathbf{b}$ & $1-50$ & $0,51 \mathbf{b}$ \\
\hline $2-100$ & $6,85 \mathbf{a}$ & $2-100$ & $0,55 \mathbf{a}$ \\
\hline \multicolumn{4}{|c|}{ Pressão dentro do aglutinante 2 (sorgo) } \\
\hline $\begin{array}{c}\text { Pressão } \\
\left(\mathrm{kgf} / \mathrm{cm}^{2}\right)\end{array}$ & $\begin{array}{l}\text { Umidade } \\
(\%)\end{array}$ & $\begin{array}{c}\text { Pressão } \\
\left(\mathrm{kgf} / \mathrm{cm}^{2}\right)\end{array}$ & $\begin{array}{c}\text { Densidade } \\
\left(\mathrm{g} / \mathrm{cm}^{3}\right)\end{array}$ \\
\hline $1-50$ & $6,65 \mathbf{a}$ & $1-50$ & $0,50 \mathbf{b}$ \\
\hline $2-100$ & $6,62 \mathbf{a}$ & $2-100$ & $0,52 \mathbf{a}$ \\
\hline
\end{tabular}

Obs: as médias seguidas pela mesma letra não diferem estatisticamente entre si na mesma coluna. 
Tabela 29. Análise da interação aglutinante x pressão.

\begin{tabular}{ll|ll}
\hline \multicolumn{4}{c}{ Aglutinante dentro da pressão 1 (50) } \\
\hline Aglutinante & Umidade & Aglutinante & Densidade \\
\hline $\mathbf{1}$ - milho & $6,58 \mathbf{a}$ & 1 - milho & $0,51 \mathbf{a}$ \\
$\mathbf{2}$ - sorgo & $6,65 \mathbf{a}$ & 2 - sorgo & $0,50 \mathbf{a}$ \\
\hline \multicolumn{4}{l}{ Aglutinante dentro da pressão 2 (100) } \\
\hline Aglutinante & Umidade & Aglutinante & Densidade \\
\hline $\mathbf{1}$ - milho & $6,85 \mathbf{a}$ & 1 - milho & $0,55 \mathbf{a}$ \\
$\mathbf{2}$ - sorgo & $6,62 \mathbf{b}$ & 2 - sorgo & $0,52 \mathbf{b}$ \\
\hline
\end{tabular}

Obs: as médias seguidas pela mesma letra não diferem estatisticamente entre si na mesma coluna.

Conforme se observa na Tabela 28, o efeito da pressão sobre a densidade aparente foi estatisticamente significativo tanto para o aglutinante de milho quanto para sorgo. Por outro lado quando se analisa a pressão em relação a umidade, o efeito estatístico significativo é observado somente para o aglutinante de milho.

A análise do efeito do aglutinante nas mesmas variáveis considerando as pressões, conforme a Tabela 29 , nota-se que para a pressão de $50 \mathrm{kgf} / \mathrm{cm}^{2}$ não há efeito significativo do aglutinante, mas para a pressão de $100 \mathrm{kgf} / \mathrm{cm}^{2}$ há, tanto para a densidade aparente quanto para a umidade.

A densidade dos compactados depende da densidade do resíduo lignocelulósico de origem, da pressão de briquetagem e, em certo grau, do tempo e temperatura de processamento (DERMIBAS et al., 2004). Geralmente os materiais com maior umidade e tamanhos de partículas maiores tendem a reduzir a densidade do produto final, enquanto que as temperaturas e pressões de processo mais elevadas aumentam a densidade dos produtos.

Melo (2000) avaliando briquetes produzidos com moinha de carvão vegetal e alcatrão de madeira com pressão de compactação de 195, 260 e $325 \mathrm{kgf} / \mathrm{cm}^{2}$ e diferentes proporções de aglutinante, encontrou um valor médio de densidade aparente de 0,62, 0,64 e $0,67 \mathrm{~g} / \mathrm{cm}^{3}$, respectivamente. Quirino \& Brito (1991), analisando características e índice de combustão de briquetes de carvão vegetal comerciais, analisaram quatro procedências de briquetes, produzidos no Brasil, nos Estados Unidos da América e duas da Argentina e encontraram densidades aparente variando de 0,69 a 0,99 $\mathrm{g} \mathrm{cm}^{3}$. Segundo Dias et al. (2012) em geral, a densidade aparente dos briquetes varia entre 500 e $1200 \mathrm{~kg} / \mathrm{m}^{3}$.

Foi possível verificar o ganho de aproximadamente quatro vezes, proporcionado pelos briquetes em termos de quantidade de material por volume em comparação com os 
finos do carvão, semelhante ao observado por Furtado et al. (2010) e Mendes (1993). Isso contribui expressivamente para a redução dos custos de transporte do material combustível.

A tabela 30 contém os valores de " $F$ " para resistência a compressão paralela dos briquetes.

Tabela 30. Valores de "F" para resistência a compressão paralela.

\begin{tabular}{lll}
\hline \multirow{1}{*}{ FV } & GL & \multicolumn{1}{l}{ Valores de "F" } \\
\cline { 3 - 3 } & & RCP \\
\hline Aglutinante & 1 & $2,69 \mathrm{~ns}$ \\
\hline Pressão & 1 & $63,21 * *$ \\
\hline Mistura & 1 & $85,88 * *$ \\
\hline Aglu x Pres & 1 & $<1 \mathrm{~ns}$ \\
\hline Aglu x Mist & 1 & $2,73 \mathrm{~ns}$ \\
\hline Pres x Mist & 1 & $2,33 \mathrm{~ns}$ \\
\hline Aglu x Pres x Mist & 1 & $4,27 \mathrm{~ns}$ \\
\hline Resíduo & 16 & \\
\hline Total & 23 &
\end{tabular}

** significativo ao nível de $1 \%$ de probabilidade $(\mathrm{p}<.01)$

* significativo ao nível de $5 \%$ de probabilidade $(.01=<\mathrm{p}<.05)$

ns não significativo $(\mathrm{p}>=.05)$

Pode-se observar na tabela 30 que o tipo de aglutinante não interferiu na resistência a compressão paralela sendo influenciada apenas pela pressão e mistura. Observou-se ainda, aumentos significativos na resistência à compressão dos briquetes com o aumento da pressão e a proporção de aglutinante na composição dos mesmos.

Os briquetes confeccionados utilizando o aglutinante de resíduos de milho na proporção de 60/40, e submetidos a pressão de $100 \mathrm{kgf} / \mathrm{cm}^{2}$, apresentaram os maiores valores de resistência a compressão, 81,03 kgf, destacando-se dos demais.

Notou-se ainda que, este tratamento apresentou o maior valor de densidade aparente, corroborando com os estudos realizados por Paula (2010) que afirmou que os briquetes de maior densidade possuem maior resistência à compressão.

Benício (2011) estudando a utilização de diferentes proporções de resíduo celulósico na composição de briquetes de finos de carvão vegetal encontrou para resistência a compressão paralela dos briquetes valores variando de 5,57 a 25,80 kgf sendo que os briquetes que apresentaram os melhores resultados foram os com maior proporção 
do aglutinante. No mesmo estudo a autora acrescentou $10 \%$ de amido de milho nas proporções do resíduo celulósico e obteve valores bastante superiores de resistência a compressão, variando de 36,40 a $85,40 \mathrm{kgf}$, sendo que os briquetes que apresentaram os melhores resultados foram os que continham apenas os $10 \%$ de amido como aglutinante (testemunha) ou as menores proporções de resíduo celulósico.

\subsubsection{Análise imediata}

Na Tabela 31 são apresentados os valores médios para os teores de matérias voláteis (MV), de cinza (CZ) e de carbono fixo (CF) dos briquetes.

Tabela 31. Análise imediata dos briquetes.

\begin{tabular}{cccc}
\hline Tratamentos & MV & CZ & CF \\
& $(\%)$ & $(\%)$ & $(\%)$ \\
\hline \multirow{2}{*}{ T1 (M-50-60/40) } & 33,65 & 7,84 & 58,50 \\
& $(2,31)$ & $(0,79)$ & $(1,43)$ \\
T2 (M-50-70/30) & 30,84 & 8,16 & 61,00 \\
& $(1,43)$ & $(0,24)$ & $(0,73)$ \\
T3(M-100-60/40) & 34,44 & 7,71 & 58,85 \\
& $(0,85)$ & $(1,21)$ & $(0,63)$ \\
T4(M-100-70/30) & 30,68 & 8,06 & 61,26 \\
& $(0,35)$ & $(2,66)$ & $(0,35)$ \\
T5(S-50-60/40) & 33,11 & 8,89 & 58,00 \\
& $(3,43)$ & $(1,79)$ & $(1,91)$ \\
T6(S-50-70/30) & 31,10 & 8,85 & 60,05 \\
& $(1,79)$ & $(0,91)$ & $(0,98)$ \\
T7(S-100-60/40) & 32,93 & 8,68 & 58,39 \\
& $(0,65)$ & $(1,66)$ & $(0,56)$ \\
T8(S-100-70/30) & 30,76 & 8,76 & 60,48 \\
& $(0,39)$ & $(3,50)$ & $(0,31)$ \\
\hline
\end{tabular}

Obs: M e S - aglutinantes de milho e sorgo; 50 e 100 - pressão em kgf/cm²; 60/40 e 70/30 - mistura de carvão/aglutinante. Valores entre parênteses correspondem ao coeficiente de variação.

Conforme pode ser visualizado na tabela 31 , os briquetes com maior quantidade de aglutinante na composição apresentaram maior teor de materiais voláteis. Em contra partida, os briquetes com os maiores teores de carvão vegetal na composição a liberação de compostos voláteis foi menos intensa, uma vez que à degradação térmica ocorrida no processo de carbonização gera a eliminação de parte dos materiais voláteis. A tabela 32 contém os valores de "F" para a análise imediata dos briquetes.

Tabela 32. Valores de "F" para análise imediata.

\begin{tabular}{lll}
\hline FV & GL & Valores de "F" \\
\hline
\end{tabular}




\begin{tabular}{lcccc}
\hline & \multicolumn{1}{c}{ MV } & CZ & CF \\
\hline Aglutinante & 1 & $<1 \mathrm{~ns}$ & $171,94 * *$ & $8,05 *$ \\
\hline Pressão & 1 & $<1 \mathrm{~ns}$ & $5,65 *$ & $2,64 \mathrm{~ns}$ \\
\hline Mistura & 1 & $118,68^{* *}$ & $9,34 * *$ & $93,97 * *$ \\
\hline Aglu x Pres & 1 & $<1 \mathrm{~ns}$ & $<1 \mathrm{~ns}$ & $<1 \mathrm{~ns}$ \\
\hline Aglu x Mist & 1 & $2,38 \mathrm{~ns}$ & $3,94 \mathrm{~ns}$ & $<1 \mathrm{~ns}$ \\
\hline Pres x Mist & 1 & $<1 \mathrm{~ns}$ & $<1 \mathrm{~ns}$ & $<1 \mathrm{~ns}$ \\
\hline Aglu x Pres x Mist & 1 & $<1 \mathrm{~ns}$ & $<1 \mathrm{~ns}$ & $<1 \mathrm{~ns}$ \\
\hline Resíduo & 16 & & & \\
\hline Total & 23 & & & \\
\hline
\end{tabular}

** significativo ao nível de $1 \%$ de probabilidade $(\mathrm{p}<.01)$

* significativo ao nível de $5 \%$ de probabilidade $(.01=<\mathrm{p}<.05)$

ns não significativo $(\mathrm{p}>=.05)$

De acordo com a tabela 31, observa-se que os briquetes produzidos com o aglutinante de resíduos de milho apresentaram menor teor de cinzas que os produzidos com aglutinantes de resíduos de sorgo. A pressão não influenciou nos teores de materiais voláteis, cinzas e carbono fixo, sendo a mistura o fator mais relevante.

Constatou-se ainda que, diminuindo as porcentagens de aglutinante na formulação dos briquetes foram aumentados os percentuais de cinzas dos mesmos, evidenciando que, neste caso, a utilização destes aglutinantes não implica em aumento no teor de cinzas do briquete. Contudo, o alto teor de cinzas pode estar relacionado às características dos carvões que deram origem à mistura utilizada para confecção dos briquetes, como por exemplo, o carvão de palha de feijão, o qual apresenta $21,57 \%$ de teor de cinzas. Altos percentuais de cinzas nos briquetes são indesejáveis, uma vez que as cinzas contribuem para redução do seu poder calorífico, além de ter implicações quanto ao sistema de limpeza em fornalhas e incrustações em tubulações.

De forma inversa ao observado para o teor de materiais voláteis, pode-se observar um acréscimo do carbono fixo dos briquetes à medida que diminui a quantidade de aglutinante na formulação dos briquetes. O maior valor médio de carbono fixo foi encontrado nos briquetes produzidos com pressão de $100 \mathrm{kgf}$, aglutinante de resíduos de milho e proporção de 70/30, evidenciando que quanto menor quantidade de aglutinante adicionado aos finos para produção de briquetes, maior será o teor de carbono fixo e, consequentemente, maior o poder calorífico. 


\subsubsection{Poder Calorífico e Densidade Energética}

A Tabela 33 apresenta os resultados obtidos para a variável poder calorífico superior (PCS) e densidade energética dos briquetes.

Tabela 33. Poder calorífico superior e densidade energética.

\begin{tabular}{|c|c|c|c|}
\hline \multicolumn{2}{|c|}{ Tratamentos } & \multirow{2}{*}{$\begin{array}{c}\text { PCS } \\
(\mathrm{kcal} / \mathrm{kg})\end{array}$} & \multirow{2}{*}{$\begin{array}{c}\mathrm{DE} \\
(\mathrm{Mcal} / \mathrm{kg})\end{array}$} \\
\hline Aglutinante & Mistura & & \\
\hline \multirow{2}{*}{ Resíduos de milho } & $60 / 40$ & $\begin{array}{c}6360,53 \\
(0,40)\end{array}$ & $\begin{array}{c}3466,49 \\
(0,40)\end{array}$ \\
\hline & $70 / 30$ & $\begin{array}{c}6454,39 \\
(0,92)\end{array}$ & $\begin{array}{c}3323,83 \\
(0,45)\end{array}$ \\
\hline \multirow{2}{*}{ Resíduos de sorgo } & $60 / 40$ & $\begin{array}{c}6330,80 \\
(1,23)\end{array}$ & $\begin{array}{c}3312,88 \\
(0,77)\end{array}$ \\
\hline & $70 / 30$ & $\begin{array}{c}6409,57 \\
(0,33)\end{array}$ & $\begin{array}{c}3183,42 \\
(0,70)\end{array}$ \\
\hline
\end{tabular}

Obs.: 60/40 e 70/30 - mistura de carvão/aglutinante. Valores entre parênteses correspondem ao coeficiente de variação

Furtado et al. (2010), em seu estudo sobre as variáveis do processo de briquetagem e a qualidade do briquete de biomassa florestal, onde avaliou o efeito de três níveis de pressão (baixa, média e alta) sobre a variável poder calorífico, constatou que não houve diferença significativa entre os tratamentos afirmando que, considerando apenas a variável PCS, pode-se indicar o uso da baixa pressão, pois demanda um menor dispêndio de energia com resultados satisfatórios.

Neste sentido, desconsiderou-se o fator pressão para o estudo do poder calorífico e densidade energética. A tabela 34 contém os valores de " $F$ " para poder calorífico e densidade energética.

Tabela 34. Valores de "F" para poder calorífico superior e densidade energética.

\begin{tabular}{lccc}
\hline \multirow{2}{*}{ FV } & GL & \multicolumn{2}{c}{ Valores de "F" } \\
\cline { 3 - 4 } & & PCS & DE \\
\hline Aglutinante & 1 & $1.5699 \mathrm{~ns}$ & $166.7478 * *$ \\
\hline Mistura & 1 & $8.4173 *$ & $142.8251 * *$ \\
\hline Aglu x Mist & 1 & $0.0644 \mathrm{~ns}$ & $0.3358 \mathrm{~ns}$ \\
\hline Resíduo & 8 & & \\
\hline Total & 11 & &
\end{tabular}

** significativo ao nível de $1 \%$ de probabilidade $(\mathrm{p}<.01)$

* significativo ao nível de $5 \%$ de probabilidade $(.01=<p<.05)$ 
ns não significativo $(\mathrm{p}>=.05)$

O coeficiente de variação foi baixo sendo 0,59 e $0,81 \%$, para PCS e DE respectivamente, menor que $10 \%$, o que indica que o experimento foi bem controlado.

Analisando a Tabela 34, observa-se que os tipos de aglutinantes estudados não influem no poder calorífico superior dos briquetes. $\mathrm{O}$ aumento da porcentagem do aglutinante implicou em uma diminuição do poder calorífico, e isto se deve, provavelmente, ao baixo poder calorífico dos constituintes do aglutinante.

Melo (2000) pesquisando a produção de briquetes a partir de finos de carvão aglutinado com alcatrão, obteve poder calorífico médio de $7639 \mathrm{kcal} / \mathrm{kg}$, sendo este valor maior que os observados neste trabalho. Isso se deve ao tipo de aglutinante utilizado para a produção dos briquetes, visto o alto poder energético do alcatrão, que ultrapassa o valor médio de $8.000 \mathrm{Kcal} / \mathrm{kg}$.

Para a densidade energética tem-se que, tanto o aglutinante quanto a mistura são relevantes na análise, sendo o aglutinante de resíduos de milho e a proporção de 60/40 estatisticamente superiores, demonstrando um maior potencial para geração de energia. 


\section{CONCLUSÕES}

Os resíduos de palha de café in natura apresentaram as melhores propriedades para o uso em combustão direta devido, principalmente, aos valores de densidade a granel e densidade energética, implicando em maior produção de energia por unidade volumétrica, otimizando assim o uso em aparelhos de queima.

Os resíduos agroflorestais transformados em carvão vegetal apresentaram propriedades adequadas para consumo como insumo energético. No entanto, a palha de feijão apresentou características inferiores às demais biomassas analisadas. Quando comparado com os resíduos madeireiros, o teor médio de cinza da palha de feijão pode ser 15 vezes maior, o que induz à utilização de sistemas de limpeza mais eficientes entre outros cuidados.

Ao buscar a produtividade e a qualidade do carvão vegetal, deve-se optar pelo carvão de resíduos de madeira de construção civil e madeira de madeireira, em razão dos bons rendimentos gravimétricos, carbono fixo e densidade energética apresentados, associados ao menor teor de cinzas no carvão. Dentre os resíduos agrícolas a palha de café se sobressai. Este insumo pode ser consumido, por exemplo, nas indústrias cimenteiras, cerâmicas, alimentícias e na secagem de grãos.

É possível utilizar aglutinantes produzidos a partir de alguns dos resíduos agrícolas na produção de briquetes de carvão vegetal. A quirela de milho e de sorgo, por terem altos teores de amido, podem ser utilizados como aglutinantes, diminuindo os custos de produção de briquetes.

O estudo revela uma alternativa interessante no aproveitamento conjunto de dois tipos de resíduos, contribuindo para uma melhoria na gestão ambiental dos processos citados como geradores destes materiais. 


\section{RECOMENDAÇÕES}

São apresentadas sugestões para futuras pesquisas em bioenergia fundamentadas nas metodologias aplicadas e nos resultados obtidos:

(i) Apesar dos dados encontrados serem bons indicativos do potencial energético dos resíduos agroflorestais, requer-se que seja utilizada maior quantidade de amostragens e que novas espécies sejam estudadas.

(ii) Analisar as propriedades de cada carvão briquetado separadamente, ampliar os níveis de pressão e proporção carvão/aglutinante, aumentando as repetições de modo a melhorar a estatística.

(iii) Realizar ensaios de combustão dos materiais analisados. 


\section{REFERÊNCIAS BIBLIOGRÁFICAS}

ABIB - ASSOCIAÇÃO BRASILEIRA DE INDÚSTRIAS DA BIOMASSA. Inventário residual Brasil. 2011. Disponível em: <http://pt.calameo.com/accounts/200968>.

ABNT - Associação Brasileira de Normas Técnicas. Carvão vegetal - Determinação do poder calorífico. Método de ensaio. 01.040 - NBR 8633 OUT/1984. Origem: ABNT 1:21.01-002/84. CB-1 - Comitê Brasileiro de Mineração e Metalurgia. CE-1:21.01Comissão de Estudo de Carvão Vegetal, 13p.

ABNT - Associação Brasileira de Normas Técnicas. Carvão vegetal - Determinação da densidade relativa aparente, relativa verdadeira e porosidade. Método de ensaio.01.040 - NBR 9165 DEZ/1985. Origem: MB-2334/85 (Projeto 1:21.01-004). CB-1 - Comitê Brasileiro de Mineração e Metalurgia. CE-1:21.01-Comissão de Estudo de Carvão Vegetal, 8p.

ABNT - Associação Brasileira de Normas Técnicas. Carvão vegetal - Análise imediata. Método de ensaio. 01.040 - NBR 8112 OUT/1986. Origem: MB-1857/86. CB-1 - Comitê Brasileiro de Mineração e Metalurgia. CE-1:21.01-Comissão de Estudo de Carvão Vegetal, $5 \mathrm{p}$.

ABREU, A.F.B. Cultivo do feijão da primeira e segunda safras na região Sul de Minas Gerais. Brasília: EMBRAPA Arroz e Feijão, 2005. (Sistemas de Produção, 6).

ANTAL Jr., M. J.; GRØNLI, M. The Art, Science, and Technology of Charcoal Production. In: Ind. Eng. Chem. Res. 2003, 42, 1619 - 1640.

ANTUNES, R.C. Briquetagem de carvão vegetal. Produção e Utilização de Carvão Vegetal Belo Horizonte. CETEC Outubro, 1982.

ARRUDA, F. P. de; BELTRÃO, N. E. de M.; ANDRADE, A.P. de; PEREIRA, W. E.; SEVERINO, L. S. Cultivo de Pinhão Manso (Jatropha curcas L.) como alternativa para o Semi-Árido Nordestino. Revista Brasileira de Oleaginosas e Fibrosas, Campina Grande, v. 8, n. 1, p. 789-799, jan./abr. 2004.

ASSIS, C. F. C. Caracterização de carvão vegetal para sua injeção em altos-fornos a carvão de pequeno porte. Dissertação de Mestrado. Universidade Federal de Ouro Preto. Ouro Preto - Minas Gerais, 2008.

BASU, P. Pyrolysis and Torrefaction. In: Biomass gasification and pyrolysis Practical designandtheory Burlington: Elsevir, 2010.

BENICIO, E.L. Utilização de resíduo celulósico na composição de briquetes de finos de 
carvão vegetal. Dissertação (Mestrado em Ciências Florestais e Ambientais) Universidade Federal Rural do Rio de Janeiro. Seropédica, 2011, 55p.

BORTOLIN, T. A.; TRENTIN, A.C.; PERESIN, D.; SCHNEIDER, E. Estimativa da Geração de Resíduos Florestais no Brasil. $3^{\circ}$ Congresso Internacional de Tecnologias para o Meio Ambiente, Bento Gonçalves - RS, Brasil, p. 2-9, 25- 27 de Abril de 2012.

BRASIL. Agência Nacional de Energia Elétrica. Atlas de energia elétrica do Brasil: parte II, fontes renováveis: biomassa. 3. ed. Brasília, 2008. 74 p.

BRITO, O. J.; FERREIRA, M.; BARRICHELO, L.E.G. Correlações entre características físicas e químicas da madeira e a produção de carvão vegetal: Densidade Básica da madeira x Densidade Aparente do carvão - Perspectivas de melhoramento. Boletim Informativo, ESALQ/USP: Piracicaba, 6(16): p.1-9, jul. 1978.

BRITO, J.O. Expressão da produção flrestal em unidades energéticas. P. 280-82. In: 1o Congtresso Florestal Panamericano e 7o Congresso Florestal Brasileiro. Curitiba-Pr. 1993. BRIDGWATER, A. V. Biomass Fast Pyrolysis. Thermal Science, v. 8, n. 2, 2004. p. 21 49.

CARASCHI, J. C.; PINEIRO, D. G.; VENTORIM, G. Caracterização física e química dos pellets de madeira produzidos no brasil. UFES/Vitória, 2012.

CARDOSO, M. T. Desempenho de um sistema de forno-fornalha para combustão de gases na carbonização da madeira. Dissertação de Mestrado. Programa de Pós-Graduação em Ciência Florestal. Universidade Federal de Viçosa. Viçosa - Minas Gerais, 2010.

CARVALHO, F.C. Disponibilidade de resíduos agroindustriais e do beneficiamento de produtos agrícolas. In: SIMPÓSIO SOBRE UTILIZAÇÃO DE SUBPRODUTOS AGROINDUSTRIAIS E RESÍDUOS DE COLHEITA NA ALIMENTAÇÃO DE RUMINANTES, 1., 1992, São Carlos. Anais... São Carlos: UEPAE, 1992. p.7-27.

CASTRO, A. F. N. M. Efeito da idade e de matérias genéticos de Eucalyptus sp. na madeira e carvão vegetal. Dissertação de Mestrado. Universidade Federal de Viçosa. Viçosa - Minas Gerais, 2011.

CORTEZ, L. A.B; LORA, E. E. S.; GOMEZ, E. O. Revista Biomassa para energia. Campinas, SP: Unicamp, 732 p., 2008.

COSTA, R. S. C.; TOWNSEND, C. R.; LEÔNIDAS, F. C. Diversas utilidades da casca de café - Informe tecnológico $\mathbf{N}^{\mathbf{0}}$ 043. In: EMBRAPA RONDÔNIA. Disponível em: <http://www23.sede.embrapa.br:8080/aplic/cafenews.nsf/5f67c50917e85d1b03256c10 00503fd9/a64f3e1114f84a3703256c22006ca794?OpenDocument>. Acessado em 12 Fev. 
20016.

COUTO, L. C. et al. Vias de valorização energética da biomassa. Biomassa \& Energia, Viçosa, MG, v. 1, n. 1, p. 71-92, 2004.

CONAB - Companhia Nacional de Abastecimento. Avaliação da safra agrícola cafeeira $1^{\text {a }}$ Estimativa - Janeiro/2011. Brasília: CONAB, 2011. 25p.

CHAVES, A.M.B.; VALE, A.T.; MELIDO, R.C.N.; ZOCH, V.P. Características energéticas da madeira e carvão vegetal de clones de Eucalyptus spp. Enciclopédia Biosfera, v.9, n.17; p.533-542. 2013.

DAYTON D. C.; JENKINS B. M.; TURN S. Q.; BAKKER R. R.; WILLIANS R.B.; BELLEOUDRY D.; HILL L. M. Release of inorganics constituents from leached biomass during thermal conversion. Energy \& Fuels, v. 13, n. 4, p. 860-870. 1999.

DIAS, J. M. C. S.; SOUZA, D. T.; BRAGA, M.; ONOYAMA, M. M.; MIRANDA, C. H. B.; BARBOSA, P. F. D.; ROCHA, J. D. Produção de briquetes e péletes a partir de resíduos agrícolas, agroindustriais e florestais. EMBRAPA Agroenergia: Brasília, DF. Documentos 13.2012. 130 p.

DEMAJORIVIC, J. Da política tradicional de tratamento do lixo à política de gestão de resíduos sólidos: as novas prioridades. Revista de Administração de Empresas, São Paulo, v35, n 3m p88-93, 1995.

DEMIRBAS, A; DEMIRBAS, H. A. Estimating the calorific values of lignocellulosic fuels. Journal Energy, Exploration \& Exploitation, v. 20, n. 1, p. 105-111, 2004.

DEZAJACOMO, G. Caracterização de biomassa vegetal para fins energéticos. Trabalho de graduação do Curso de Engenharia Industrial. Itapeva, 2010.

EPE - Empresa de Pesquisa Energética. Balanço Energético Nacional 2015 - Ano Base 2014. Rio de Janeiro: EPE, 2015. 291 p.

FELFLI, F. F et al. Biomass briquetting and its perspectives in brasil. Biomass and Bioenergy, Oxford, V. 35, n. 1, p. 236-242, jan. 2011.

FERNANDES, U. COSTA, M. Potencial of biomass residues for energy production and utilization in a region of Portugal. Biomass Bioenergy. 2010; 34(5):661-6.

FONTES, P.J.P. de; QUIRINO, W.F.; PASTORE JUNIOR, F.; FILGUEIRAS, S.M.S. Aglutinante para briquetagem de carvão vegetal. Brasília: DPQ/IBDF, 1984. 
FONTES, P.J.P. Auto-sufuciência energética em serraria de Pinus e aproveitamento de resíduos. 93f. Dissertação (Mestrado em Ciências Florestais) - Setor de Ciências Agrárias, Universidade Federal do Paraná. 1994.

FRIEDL, A.; PADOUVAS, E.; ROTTER, H.; VARMUZA, K. Prediction of heating values of biomass fuel from elemental composition. Analytica Chimica Acta, v. 544, n. 12, p. 191-198, 2005.

GARCIA, D. P. Caracterização química, física e térmica de pellets de madeira produzidos no Brasil. Dissertação de Mestrado. Universidade Estadual Paulista. Faculdade de Engenharia de Guaratinguetá. Guaratinguetá, 2010.

GENTIL, L. V. B. Tecnologia e Economia do Briquete de Madeira. Tese de doutorado. Departamento de Engenharia Florestal, Universidade de Brasília - EFL/UnB: Brasília, DF. 2008. 195 p.

GIRARD, P.; SHAH, N. Recent developments on torrefied wood, an alternative to charcoal for reducing deforestation. REUR Tech. Ser. Vol. 20. 1991. pp. 101-104.

GRANADA, E.; LÓPEZ GONZÁLEZ, L. M.; MÍGUEZ, J. L.; MORAN, J. Fuel lignocellulosic briquettes, die design and products study. Renewable Energy, Oxford, GB, v. 27, n. 4 , p. 561-573, 2002.

GONÇALVES, J. E. et al. Energia de briquetes produzidos com rejeitos de resíduos sólidos urbanos e madeira de Eucalyptus grandis. Revista Brasileira de Engenharia Agrícola e Ambiental, Campina Grande, v. 13, n. 5, p. 657-661, 2009.

GOMES, R.A.R. Avaliação do desempenho de uma fornalha a lenha de fluxo descendente e com sistema de aquecimento direto. Viçosa, MG: UFV, 1988. 56 p. Dissertação (Mestrado em Engenharia Agrícola) - Universidade Federal de Viçosa, 1988.

HUANG, C.; HAN, L.; YANG, Z.; LIU, X. Ultimate analysis and heating value prediction of straw by near infrared spectroscopy. Waste Management, v. 29, n. 6, p. 1793-1797, 2009.

IEA- International Energy Agency, Key World Energy Statistics. 2011. Xxp.

INTERNATIONAL ENERGY AGENCY - IEA. Technology roadmap: Bioenergy for Heat and Power. OECD/IEA, Paris/France, 2011.

JARA, E. R. P. O poder calorífi co de algumas madeiras que ocorrem no Brasil. São Paulo: Instituto de Pesquisas Tecnológicas, 1989. (Comunicação técnica, 1797). 
JENKINS, B. M. Fuel Properties for Biomass Materials. In: International Symposium on Application and Management of Energy in Agriculture: The Role of Biomass Fuels. May, Delhi, India, p. 21-23, 1990.

JENKINS, B. M. Physical properties of biomass. In: KITANI, O.; HALL, C. W. (Eds.). Biomass Handbook. New York: Gordon \& Breach, 1989. p. 860-891.

KANURY, A. (1994). Combustion characteristics of biomass fuels, Combustion Science and Technology 97: $469-491$

KLAUTAU, J. P von. Análise experimental de uma fornalha a lenha de fluxo co-corrente para secagem de grãos. Curitiba, 2008, 192p. Dissertação (Mestrado) - Programa de PósGraduação em Engenharia de Recursos Hídricos e Ambiental, Universidade Federal do Paraná, 2008.

KLOCK, H., MUÑIZ, G. I., HERNANDEZ, J. A., \& ANDRADE, A. S. (2005). Química da Madeira ( $3^{\mathrm{a}}$ - Revisada ed.). Curitiba, Paraná, Brasil: UNIVERSIDADE FEDERAL DO PARANÁ - UFPR.

LIMA, E. A. Alternativa para estimar o preço da madeira para energia. Comunicado Técnico. Embrapa Florestas, Colombo - PR, dezembro, 20p, 2010.

LIMA, E. A.; SILVA, H. D.; LAVORANTI, O., J. Caracterização dendroenergética de árvores de Eucalyptus benthamii. Revista Pesquisa Florestal Brasileira, v.31, p.09-17, 2011.

LOPES, R. P., OLIVEIRA FILHO, D., DONZELES, S. M. L. et al. Controle da combustão em fornalhas a lenha.. In: ENCONTRO DE ENERGIA NO MEIO RURAL, 3., 2000, Campinas. Proceedings online... Available from: <http://www.proceedings.scielo.br/scielo.php?script=sci_arttext\&pid=MSC000000002200 0000200023\&lng=en\&nrm=abn>. Acess on: 15 Sep. 2016.

LYND, L. R, VAN, Z. W. H, MCBRIDE, J. E, LASER, M. Consolidated bioprocessing of cellulosic biomass: an update. Curr. Opin. Biotechnology, 16, 577, 2005.

MAGALHÃES, A. L. R. Resíduo proveniente do beneficiamento do feijão em rações para bovinos. 2005. Doutorado (Zootecnia) - Universidade Federal de Viçosa, Viçosa, MG.

MARSOLLA, A. Planta de briquetagem de carvão vegetal. São Paulo: Rosa Madeireira, 1998. $76 \mathrm{p}$.

MATARELLI, F. A.; LOPES, L. E. F.; CASTRO, L. F. A. Siderurgia a carvão vegetal. In: Biomassa, Energia dos Trópicos em Minas Gerais. Mello, Marcello Guimarães (org.). Belo Horizonte: LabMídia/FAFICH, 2001. p. 145 - 162. 
MATOS, A. T.; MONACO, P. A.; GARCIA, G. O. Caracterização dos resíduos sólidos e líquidos no processamento dos frutos do cafeeiro. In: PÓS-COLHEITA CBP\&D/Café - UFV. <http://www.ufv.br/poscolheita/aguas/caracterizacao.htm>. Acessado em: 15 set. 20016.

MCKENDRY, P. Energy production from biomass (part 1): overview of biomass. Bioresource Technology, 83, 37, 2002.

MOERS, E. M.; VIEIRA, A. C.; FERNANADES, D. M.; SOUZA, S. N. M.; BARICCATTI, R. A. Caracterização da biomassa residual proveniente de resíduos agrícolas para geração de energia. I COLASSA - Congresso Latino Americano de Suinocultura e Sustentabilidade Ambiental, Anais... Foz do Iguaçu, 2011.

MUNALULA, F.; MEINCKEN, M. An evaluation of South African fuelwood with regards to calorific value and environmental impact. Biomass and Bioenergy, Oxford, v.33, n.3, p.415-420, Mar. 2009.

NOGUEIRA, L. A. H.; LORA, E. E. S.; TROSSERO, M. A.; FRISK, T. Dendroenergia: fundamentos e aplicações. Brasília, DF: ANEEL. 2000.144 p.

NOGUEIRA, M.F.M.; RENDEIRO, G. Caracterização Energética da Biomassa Vegetal. In: BARRETO, E.J.F. (Coord). Combustão e Gaseificação da Biomassa Sólida: Soluções Energéticas para a Amazônia. Brasilia: Ministério de Minas e Energia, 2008.

OHANA, C. C. Utilização de resíduos do processamento de teca (Tectona grandis L.f.) na produção de briquetes. Dissertação (Mestrado em Ciências Ambientais e Florestais). Universidade Federal Rural do Rio de Janeiro, Seropédica, RJ, 2012, 63p.

OLIVEIRA, de J.L; SILVA, da J.N; PEREIRA, E.G; Filho, D.O; CARVALHO, D.R. Characterization and Mapping of Waste from Coffee and Eucalyptus Production in Brazil for Thermochemical Conversion of Energy Via Gasification. Renewable and Sustainable Energy Reviews, 21, 52-58, 2013.

PALLAVI, H. V.; SRIKANTASWANY, S.; KIRAN, B. M.; VYSHNAVI, D. R.; ASHWIN, C. A. Briquetting Agricultural Waste as Energy Source. Journal of Environmental Science, Computer Science and Engineering \& Technology. Vol. 2, $\mathrm{n}^{\circ}$. 1. 2013. pp 160-172.

PARIKH, J.; CHANNIWALA, S. A.; GHOSAL, G. K. A correlation for calculating HHV from proximate analysis of solid fuels. Fuel, v. 84, n. 5, p. 487-494, 2005.

PAULA, L. E. R.; TRUGILHO, P. F.; NAPOLI, A.; BIANCHI, M. L. Characterization of 
residues from plant biomass for use in energy generation. Cerne, Lavras, MG, v. 17, n. 2, p. 237-246, 2011.

PAULA, L. E. R. et al. Produção e avaliação de briquetes de resíduos lignocelulósicos. Pesquisa Florestal Brasileira, Colombo, v. 31, n. 66, p. 103-112, abr./jun. 2011b.

PEREIRA, R. Casca de café vira energia na Região Serrana do Espírito Santo. In: A GAZETA $\quad-\quad$ ES, $2006 . \quad$ Disponível em: <http://www.revistacafeicultura.com.br/index.php?tipo=ler\&mat=7746>. Acessado em: 11 Fev. 2007.

PINHEIRO, G.F.; RENDEIRO, G.; PINHO, J.T. Densidade energética de resíduos vegetais. Biomassa e Energia. 2006. Disponível em: . Acesso em:20/09/2016

PUROHIT, P. et al. Energetics of coal substitution by briquettes of agricultural residues. Energy, Oxford, v. 31, n. 8/9, p. 1321-1331, July 2006.

PROTÁSSIO, T. P.; ALVES, I. C. N.; TRUGILHO, P. F.; SILVA, V. O.; BALIZA, A. E. R. Compactação de biomassa vegetal visando à produção de biocombustíveis sólidos. Pesquisa Florestal Brasileira, Colombo, v. 31, n. 68, p. 273-283, 2011.

PROTÁSIO, T. P. de.; BUFALINO, L.; MENDES, R. F.; RIBEIRO, M. X.; TRUGILHO, P. F.; LEITE, E. R. da S. Torrefação e carbonização de briquetes de resíduos do processamento dos grãos de café. Revista Brasileira de Engenharia Agrícola e Ambiental, v. 16, n. 11, p $1252-1258,2012$.

PROTÁSIO, T. P.; COUTO, A. M.; REIS, A. A.; TRUGILHO, P. F. Seleção de clones de Eucalyptus para a produção de carvão vegetal e bioenergia por meio de técnicas univariadas e multivariadas. Revista Scientia Forestalis, Piracicaba, v. 42, n. 97, p. 15-28, 2013.

PROTÁSIO, T. P. de.; GOULART, S. L. ; NEVES, T. A.; ASSIS, M. R. de.; TRUGILHO, P. F. Clones comerciais de Eucalyptus de diferentes idades para o uso bioenergético da madeira. Revista Scientia Forestalis, Piracicaba, v. 42, n. 101, p. 113-127, mar. 2014.

QUIRINO, W.F. Utilização energética de resíduos vegetais. Brasília: LPF/IBAMA, 2003. 14 p.

QUIRINO, W. F.; BRITO, J. O. Características e índice de combustão de briquetes de carvão vegetal. Brasília: LPF/IBAMA, 1991. 18 p. (Série Técnica,13).

QUIRINO, W.F. Características de briquetes de carvão vegetal a seco na combustão. 1991. 80p (Dissertação de (Mestrado em Ciências Florestais) - Escola Superior de Agricultura 
“Luiz de Queiroz”. Piracicaba: ESALQ, 1991

QUIRINO, W. F., VAlE, A. T., ANDRADE, A. P., ABREU, V. L., \& Azevedo, A. C. (2004). Poder Calorífico da Madeira e de Resíduos Lignocelulósicos. Biomassa \& Energia, 1, n. 2, 173-182.

QUIRINO, F. W.; VALE, A. T.; ANDRADE, A. P. A.; ABREU, V. L. S.; AZEVEDO, A. C. S. Poder calorífico da madeira e de materiais lignocelulósicos. Revista da Madeira. Curitiba, n. 89, abril 2005. p 100-106, 2005.

RAMOS E PAULA, L. E.; TRUGILHO, P. F.; NAPOLI, A.; BIANCHI, M. L. Characterization of residues from plant biomass for use in energy generation. Cerne, v. 17, n. 2, p. 237-246, 2011.

RIBEIRO, A. S.; MACHADO, A. A. Carbonização de resíduos do processamento mecânico da madeira de eucalipto. Ciência Florestal, Santa Maria, v. 15, n. 1, p. 1-7, jan./fev. 2005.

RIVELA, B et al. Life cycle inventory of particleboard: a case study in the wood sector. International Journaul of Life Cycle Assessment, New York, v. 11, n. 2, p. 106-113, Mar. 2006.

REZENDE, Maria Emília. Produção de carvão vegetal - importância do conhecimento fundamental. Belo Horizonte: 2006.

ROCHA, F. C.; GARCIA, R.; FREITAS, A. W. P.; SOUZA, A. L. S.; GOBBI, K. F.; VALADARES FILHO, S. C.; TONUCCI, R. G.; ROCHA, G. C. Casca de café em dietas para vacas em lactação: consumo, digestibilidade, produção e composição de leite. Revista Brasileira de Zootecnia, v.35, p.2163-2171, 2006.

ROSA, M. F. et al. Valorização de resíduos da agroindústria. In: SIMPÓSIO INTERNACIONAL SOBRE GERENCIAMENTO DE RESÍDUOS AGROPECUÁRIOS E AGROINDUSTRIAIS, 2., 2011, Foz do Iguaçu. Anais... Foz do Iguaçu: SIGERA, 2011. p. 98-105.

SANTIAGO, A. R.; ANDRADE, A. M. Carbonização de resíduos do processamento mecânico da madeira de eucalipto. Ciência Florestal. v. 15, n. 1, p. 1-7, 2005.

SANTIAGO, S.L.F. Aproveitamento de Resíduos Florestais de Eucalyptus spp. na Indústria de Fabricação de Celulose para Geração de Energia Térmica e Elétrica. Tese (Doutorado)- Universidade Estadual Paulista, Faculdade de Ciências Agronômicas, Botucatu, p. 1-109, 2013. 
SANTOS, J. M. C. F. Avaliação da biomassa de plantas bioenergéticas. 2009, 79p. Dissertação de Mestrado. Instituto Superior de Agronomia. Universidade Técnica de Lisboa, 2009.

SALEME, J.E.F. Estudo básico para briquetagem do carvão vegetal. Ouro Preto: Escola de Minas e Metalurgia, 1992. 19p.

SCARLAT, N. BLUJDEA, V. DALLEMAND, J. Assessment of the availability of agricultural and forest residues for bioenergy production in Romania. Biomass Bioenergy. 2011; 35(5):1995-2005.

SCHNEIDER, V.E.; PERESIN, D.; TRENTIN, A.C.; BORTOLIN, T.A.; SAMBUICHI, R.H.R. Diagnóstico dos Resíduos Orgânicos do Setor Agrossilvopastoril e Agroindústrias Associadas. Relatório de Pesquisa, Instituto de Pesquisa Econômica Aplicada - IPEA, 2012.

SFB 2015: http://www.florestal.gov.br/snif/producao-florestal/consumo

SILVA, J. L. P. da. Aproveitamento de resíduos da indústria madeireira para geração de energia elétrica: O caso da empresa B. K. energia Itacoatiara Ltda. no estado do Amazonas. Curitiba, 33p. Trabalho apresentado para o Departamento de Ciências florestais da Universidade Federal do Paraná, 2011.

SILVA, J. V. H; BITTAR, A.P; SERRA, J. C. V; JÚNIOR, J. C. Z. Diagnóstico do Reaproveitamento de Resíduos com Potencial Energético no Município de Palmas-TO. Revista de Engenharia Ambiental, Espírito Santo do Pinhal, v.8, n.2, p. 226-233, abr./jun. 2011.

SILVA, D. Avaliação da eficiência energética em uma indústria de painéis compensados. 182f. Tese (Doutorado em Ciências Florestais) - Setor de Ciências Agrárias Universidade Federal do Paraná. Curitiba. 2001.

SILVA, I.D. Projeto, construção e teste de uma fornalha a carvão vegetal para secagem de café. Viçosa: Universidade Federal de Viçosa, 1998. 81p. (Tese, Mestrado em Engenharia Agrícola).

SAGLIETTI, J.R.C. Rendimento térmico de fornalha a lenha de fluxos cruzados. Botucatu: Universidade Estadual Paulista, 1991. 102p. (Tese, Doutorado Agronomia).

SIDRA, IBGE acesso: 15/04/2016 Disponível em: $<$ http://www.sidra.ibge.gov.br/bda/agric/>. 
SHONHIWA, G. Assessment of biomass residues sustainably available for thermochemical conversion to energy in Zimbabwe. Biomass Bioenergy. 2013; 52:131-8.

SOARES, C.P.B.; NETO, F. de P.; SOUZA, A.L. de. Dendrometria e Inventário Florestal. Viçosa: Ed.UFV, 2006. 278p.

SORENSEN, B. Renewable Energy: Its physics, engineering, use, environmental impacts, economy and planning aspects. Elsevier: London. 2004. 945 p.

SOUZA, M.M. Caracterização e viabilidade econômica do uso energético de resíduos da colheita florestal e do processamento de Pinus taeda L. 2010. Dissertação (Mestrado) Universidade Federal do Paraná, Curitiba, 2010. 77p.

TABARÉS, J., ORTIZ, L., VIAR, F. (2000). Feasibility study of energy use for densificated lignocellulosic material (briquettes), Fuel 79: 1229 - 1237

TAPPI - T 211 om-93. (s.d.). TAPPI - T 211 - Ash in wood, pul, paper and paperboard: combustion at $525^{\circ} \mathrm{C}$. Atlanta, GA: Technical Association of the Pulp and Paper Industry.

TAPPI - T222 om-88. (s.d.). TAPPI - T222 om-88 - Acid-Insoluble Lignin in Wood and Pulp. Atlanta, GA: TAPPI - Technical Association of the Pulp and Paper Industry.

TAPPI - T250. (s.d.). TAPPI - T250 - Acid-soluble lignin in wood and pulp. Atlanta, GA: Technical Association of the Pulp and Paper Industry.

TAPPI - T-264 om-88. (1996). T-264 om-88 - Preparation of wood for chemical analysis. Atlanta, GA: TAPPI - Technical Association of the Pulp and Paper Industry.

TAPPI. Preparation of wood for chemical analysis. T - 264 om -82 . TAPPI test metods. Atlanta Press. 1996a.

TAPPI. Solvent extratives of wood and pulp. T -204 om -88 . TAPPI test metods. Atlanta Press. 1996b.

TAPPI. Acid- insoluble lignina. T - 222 om - 88. TAPPI test metods. Atlanta Press. 1996c.

TIENNE, L.; DESCHAMPS, M. C.; ANDRADE, A. M. Produção de carvão e subprodutos da pirólise da casca e do bagaço da laranja (Citrus sinensis). Biomassa \& Energia, Viçosa, v. 1, n. 2, p. 191-197, 2004.

TEMPLETON, D., \& EHRMAN, T. (1995). Determination of Acid-Insoluble Lignin in Biomass - LAP-003. National Renewable Energy Laboratory - NREL. 
TEMPLETON, D., \& EHRMAN, T. (1995). Determination of acid-Soluble Lignin in Biomass - LAP-004. National Renewable Energy Laboratory - NREL.

TUMULURU, J, S.; WRIGHT, C. T.; KENNEY, K. L.; HESS, J. R. A review on biomass densification technologies for energy application. Idaho national Laboratory: IDAHO, USA. 2010. 96 p.

VALE, A. T.; BRASIL, M. A. M.; CARVALHO, C. M.; VEIGA, R.A.A. Produção de energia do fuste de Eucalyptus grandis HILL EX-MAIDEN e Acacia mangium WILLD em diferentes níveis de adubação. Revista Cerne, vol. 06, n.01, p.83-88, 2000.

VALE, A. T.; GENTIL, L. V. Produção e uso energético de biomassa e resíduos agroflorestais. In: Tecnologias aplicadas ao setor madeireiro III. Rio Branco: Suprema, 2008. p.195-241.

VALE, A. T. et al. Caracterização energética e rendimento da carbonização de resíduos de grão de café (Coffea arabica, L) e de madeira (Cedrelinga catenaeformis), DUKE. Cerne, Lavras, v. 13, n. 4, p. 416-420, out./dez. 2007.

VALE, A. T. Caracterização da Biomassa Lenhosa de um Cerrado Sensu Stricto da Região de Brasília para uso energético. 2000. Tese (Doutorado) - Universidade Estadual de São Paulo, Botucatu, 2000. 111p.

VASCO, H. COSTA, M. Quantification and use of forest biomass residues in Maputo province, Mozambique. Biomass Bioenergy. 2009; 33(9):1221-8.

VALARELLI, I.D. Desenvolvimento e teste de uma fornalha a resíduos agrícolas, de fogo indireto para secadores de produtos agrícolas. Botucatu: Universidade Estadual Paulista, 1991. 123p. (Tese, Doutorado Agronomia).

VAMVUKA, D.; TRIKOUVERTIS, M.; PENTARI, D.; ALEVIZOS, G. Evaluation of ashes produced from fluidized bed combustion of residues from oranges plantations and processing. Renewable Energy, v. 72, p. 336-343. 2014.

VILELA, F.G.; PEREZ, J.R.O.; TEIXEIRA, J.C.; REIS, S.T. Uso da casca de café melosa em diferentes níveis na alimentação de novilhos confinados. Ciência e Agrotecnologia, Lavras, v.25, n.1, p.198-205, jan./fev. 2001

VITAL, B.R. Métodos de determinação da densidade da madeira. Boletim Técnico, n.2, 1984 ,

VITAL, B.R. Métodos para determinação do teor de umidade da madeira. In: Boletim 
Técnico da Sociedade de Investigações Florestais - SIF. Universidade Federal de Viçosa. Viçosa-MG. Boletim nº13. 33p. 1997.

WERTHER, J., SAENGER, M., HARTGE, E., OGADA, T., SIAGI, Z. (2000). Combustion of agricultural residues, Progress in Energy and Combustion Science 26: 1 27

XU, F., SUN, J. X., SUN, R. C., FOULER, P., BAIRD, M. S. Comparative study of organosolv lignins from wheat straw. Industrial Crops and Products, 23, 180-193, 2006.

XU, J, THOMSEN M. H, THOMSEN A. B. Pretreatment on corn Stover with low concentration of formic acid. Journal of Microbiology Biotechnology 19, 845, 2009.

YOKOYAMA, S.; MATSUMURA, Y. (eds). The Asian Biomass Handbook - A guide for biomass production and utilization. The Japan Institute of Energy, 326 p., 2008.

ZHANG, Y. H. P, DING, S. Y, MIELENZ, J. R, CUI, J. B, ELANDER, R. T, LASER, M. Fractionating recalcitrant lignocellulose at modest reaction conditions. Biotechnology Bioengineering, 97, 214, 401-404, 2007. 